\title{
HOW CONGRESS MIGHT REDESIGN A LEANER, CLEANER WRIT OF HABEAS CORPUS
}

\author{
BRIAN M. HOFFSTADT $\dagger$
}

\begin{abstract}
In the last thirty years, the Supreme Court and Congress have made the federal writ of habeas corpus increasingly less available to state prisoners. By and large, they have restricted the writ through the creation and expansion of procedural barriers to federal habeas review. Recently, however, the policy debate over how to handle the deluge of federal habeas petitions has begun to shift away from creating procedural hurdles and toward a more straightforward narrowing of the substantive scope of the writ, as Congress has started to consider bills that would preclude state prisoners from raising certain federal constitutional claims in their habeas petitions.
\end{abstract}

This Article examines how Congress might narrow the substantive scope of the writ of habeas corpus, should it ultimately decide to do so. The Article first considers the various criteria and the underlying theories of habeas that Congress might use to select the federal constitutional claims that would remain cognizable on habeas. The Article concludes that the best guide is a theory that accommodates both the historical role of habeas as a bulwark against fundamentally unfair incarceration and the current function of habeas as an additional "appeal" from state court. The Article then delineates which

Copyright (C) 2000 by Brian M. Hoffstadt

$\dagger$ Senior Counsel, Office of Policy Development, U.S. Department of Justice; Adjunct Professor of Law, George Washington University Law School. Although the author was clerking on the Supreme Court when several of the cases discussed in this Article were handed down, the views expressed in this Article are based solely on information within the public domain. Moreover, the views are the author's own, and they do not necessarily reflect the views of the Justice Department. The author would also like to thank Bill Nardini, Scott Bales, Gregory S. Chernack, and especially Lisa R. Graves for their insightful comments and criticism. This Article is dedicated to the author's newborn niece, Lauren Makenna Schreck, who was "under development" during the same period of time as this Article. 
constitutional claims should remain available on habeas, and revisits the current procedural hurdles to see which may be eliminated or loosened. Finally, the Article briefly assesses the constitutionality of this new, narrower statutory writ.

\section{TABLE OF CONTENTS}

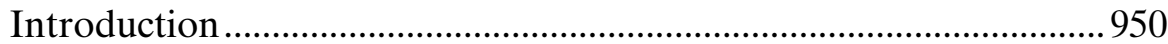

I. The Procedural Thicket ............................................................... 954

II. Narrowing the Substantive Scope .............................................. 965

A. The Broader Questions ......................................................966

B. Approaches to Narrowing Habeas....................................969

1. Full and Fair Opportunity Approach ..........................970

2. The "Colorable Innocence" Approach .......................973

3. The Temporal Approach .............................................. 975

4. The Claim-Based Approach ........................................ 979

C. Selecting Which Constitutional Rights May Be

Reheard on Habeas ................................................... 983

1. The Full Federal Forum Model ..................................984

2. The Deterrence Model ................................................986

3. The Guilt and Innocence Model..................................987

4. The Appellate Model .....................................................993

5. The "Fundamental Fairness" Model.......................... 999

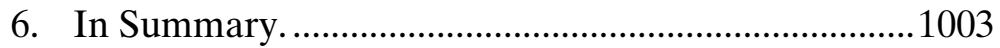

III. A Combined Theory of Habeas ................................................ 1003

A. Innocence-Based Claims ....................................................1005

1. Evidence of Innocence Existing at the Time of

Trial or Sentencing.........................................1008

2. Later-Discovered Evidence of Innocence .................1010

B. Procedures Essential to Fairness of the Criminal Process .....................................................................1013

1. Claims of Constitutional Violation That May Be Relitigated on Habeas ................................1015

a. The Fourteenth Amendment right to an orderly trial by an unbiased judge and jury.

b. The Sixth and Fourteenth Amendment right to a jury verdict.....................................................1016

c. The Sixth Amendment right to a public trial........1017

d. The Sixth Amendment right to counsel: deprivation of counsel 
e. The Sixth Amendment right to counsel: the right to represent oneself

f. The Sixth Amendment right to competent counsel

g. The Sixth Amendment right to confront witnesses.

h. The Fifth Amendment privilege against selfincrimination.

i. The Fifth Amendment guarantee against double jeopardy

j. The Fifth Amendment protection against cruel and unusual punishment

k. The Fourteenth Amendment's Due Process Clause.

2. Claims of Constitutional Violation That May Not Be Relitigated on Habeas

a. Fourth Amendment claims. ......................................1024

b. Fifth Amendment Miranda claims.........................1024

c. The Sixth Amendment right to a speedy trial.......1024

d. Sixth Amendment instructional errors. ...................1025

e. The Sixth Amendment right to the presence of counsel at identification proceedings .........1025

f. The Sixth Amendment right to competent counsel...............................................................1025

g. The Sixth Amendment right of cross-

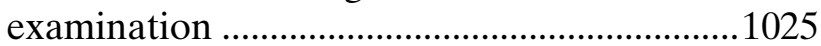

h. Fourteenth Amendment due process claims.........1026

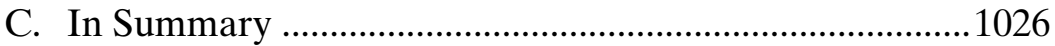

IV. Revisiting the Procedural Aspects of Habeas .........................1028

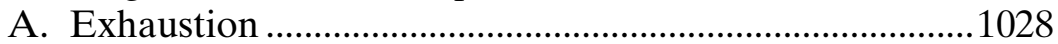

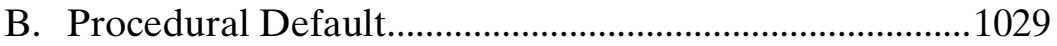

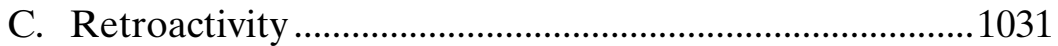

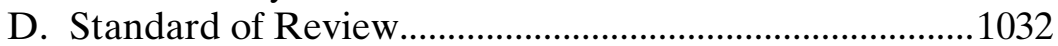

E. Standard for Relief ...........................................................1034

V. The Constitutionality of a Narrower Statutory Writ ................1035

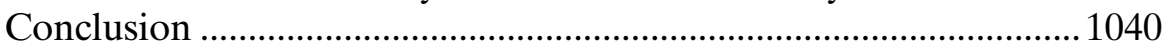




\section{INTRODUCTION}

In the last thirty years, the Supreme Court and Congress have made the federal writ of habeas corpus increasingly less available to state prisoners. ${ }^{1}$ By and large, they have restricted the writ by making it less available as a practical matter through the creation and expansion of procedural barriers to federal habeas review. They have rarely chosen to narrow the writ directly by limiting the types of federal constitutional claims that state prisoners can bring. ${ }^{2}$ Indeed, the only two changes to the substantive scope of the writ have come from the Supreme Court, which in the last three decades eliminated habeas review of Fourth Amendment claims and claims premised on developments in the law arising after a prisoner's direct appeal is over. ${ }^{3}$ Congress, by contrast, has not amended the language of the 1867

1. This Article concerns the statutory writ granting habeas jurisdiction over petitions by persons in state custody pursuant to a judgment of conviction. See 28 U.S.C. § 2254 (Supp. III 1997). This is not the only writ commonly referred to as the "writ of habeas corpus," however. There are two other statutory habeas writs: (i) one available to persons held in federal custody pursuant to a conviction, see id. $\$ 2255$ (1994), and (ii) one available to any persons held "in custody in violation of the Constitution or laws or treaties of the United States," whether before or after trial, $i d$. § 2241(c)(3) (1994). There may also be a common law writ of habeas corpus, which is much narrower than the current statutory writs and which exists solely to guard against complete deprivation of the writ. See Barry Friedman, A Tale of Two Habeas, 73 MinN. L. REV. 247, 254 (1989) [hereinafter Friedman, Two Habeas] (positing the existence of a common law writ that is independent of the statutory writ and is "narrow in scope and historically used to free prisoners subject to fundamentally unlawful incarceration"); see also infra Part V (discussing constitutional concerns affecting habeas). For state prisoners challenging their convictions, however, the Supreme Court has held that $\$ 2254$ is the sole remedy. See Brown v. Allen, 344 U.S. 443, 486 (1953) ("[F]ederal courts may not grant habeas corpus for those convicted by the state except pursuant to $\$ 2254 \ldots .$. .).

2. See 28 U.S.C. $\$ 2254$ (a) (authorizing habeas petitions for any violation of "the Constitution or laws or treaties of the United States"). Although the plain language of $§ 2254$ arguably reaches all violations of federal statutory and treaty law, this Article concentrates solely on the substantive reach of the writ with regard to constitutional claims. It should be noted, however, that the Court has limited the reach of habeas to only those federal statutory violations that qualify as "'a fundamental defect which inherently results in a complete miscarriage of justice [or] an omission inconsistent with the rudimentary demands of fair procedure."' Reed v. Farley, 512 U.S. 339, 348 (1994) (plurality) (quoting Hill v. United States, 368 U.S. 424, 428 (1962)); see also id. at 356 (Scalia, J., concurring in part and concurring in the judgment) (adopting the narrower view that "[m]ost statutory violations ... are simply not important enough to invoke the extraordinary habeas jurisdiction").

3. See Teague v. Lane, 489 U.S. 288, 294-96 (1989) (barring habeas petitioners from raising any constitutional claims based on legal developments taking place after their convictions had become final on direct appeal); Stone v. Powell, 428 U.S. 465, 494-95 (1976) (removing from the scope of habeas review claims based on violations of the Fourth Amendment's exclusionary rule). A fuller discussion of Stone and its progeny is included infra at Part II.B.3. Teague is discussed in more detail infra at Part II.A.3. 
statute defining the writ for state prisoners. That statute continues to reach all cases where any person may be restrained of her liberty in violation of the Constitution, or in violation of any treaty or law of the United States. ${ }^{4}$

Recently, however, Congress has started to consider amending the statutory writ in ways that would explicitly narrow its substantive scope..$^{5}$ In the 106th Congress, for example, Senator Orrin Hatch introduced a bill that, among other things, would remove from the scope of habeas those claims based on the admission of confessions obtained in violation of Miranda v. Arizona ${ }^{6}$ where the underlying confession was otherwise voluntary. ${ }^{7}$ Given the revived congressional interest in the federal writ's substantive scope that is reflected by this bill, the time is ripe to examine how Congress, if it ultimately decides to narrow the substantive scope of the writ, might constitutionally do so. ${ }^{8}$ In fashioning any such leaner, cleaner writ of habeas corpus,

4. See 28 U.S.C. $\$ 2254$ (a) (allowing habeas petitions for any violation of "the Constitution or laws or treaties of the United States"). The first federal statutory writ of habeas corpus was enacted as part of the Judiciary Act of 1789 and was available solely to federal prisoners. See Act of Sept. 24, 1789, ch. 20, § 14, 1 Stat. 73, 81-82. The writ was extended in 1833 to state prisoners who were arrested for committing acts authorized by federal law. See Act of Mar. 2, 1833 , ch. 57, § 7, 4 Stat. 634, 634-35. The writ was extended again in 1842 to reach state prisoners who were "subjects or citizens of foreign states, and domiciled therein." Act of Aug. 29, 1842, ch. 257, 5 Stat. 539, 539-40. The writ was not extended generally to all state prisoners until 1867. See Act of Feb. 5, 1867, ch. 28, § 1, 14 Stat. 384, 384-85.

5. No one disputes Congress's power to delineate the substantive scope of the writ. See Charles F. Baird, The Habeas Corpus Revolution: A New Role for State Courts?, 27 ST. MARY's L.J. 297, 311 (1996) ("Congress, too, certainly has the ability to amend the habeas statutes to broaden the scope of federal review."); David McCord, Visions of Habeas, 1994 B.Y.U. L. REV. 735,739 ("A point of agreement among all visions is that federal habeas for state prisoners is a creature of federal statute and that primary lawmaking authority belongs to Congress."); Gary Peller, In Defense of Federal Habeas Corpus Relitigation, 16 HARV. C.R.-C.L. L. REV. 579, 669 (1982) ("Congress, however, not the Court, has the constitutional power to determine which tribunal will vindicate federal rights."). Indeed, many argue that it should be Congress-and not the courts-that does so. See, e.g., Erwin Chemerinsky, Thinking About Habeas Corpus, 37 CASE W. RES. L. REV. 748, 765 (1987) (discussing the reasons that Congress has the power to decide the scope of habeas review).

6. 384 U.S. 436 (1966) (holding that the police must advise suspects of their rights before questioning them).

7. See Judicial Improvement Act of 1999, S. 248, 106th Cong., § 12. The constitutional underpinnings of Miranda are already under attack. See United States v. Dickerson, 166 F.3d 667, 690 (4th Cir. 1999) (holding that Miranda is not constitutionally required), cert. granted $120 \mathrm{~S}$. Ct. 578 (1999).

8. This Article takes no position on the wisdom of curtailing the writ. There are valid reasons for leaving the substantive contours of the writ untouched, some of which are discussed in greater detail infra at Part II.A. A fuller analysis of the reasons favoring and disfavoring a narrower writ is beyond the scope of this Article. Accordingly, this Article assumes for the sake of 
Congress will be called upon to balance the important role of federal habeas as a matter of criminal justice policy, its constitutionally mandated underpinnings, and the costs it imposes upon state sovereignty and upon the federal courts.

Part I of this Article provides a necessary backdrop by sketching out the current contours of the writ, as they exist in practice. To do so, this part begins by describing the patchwork of procedural and quasi-procedural doctrines that the Supreme Court and Congress have developed in the past thirty years and turns to an examination of how those doctrines work together to make it more difficult for state prisoners to present and prevail upon their federal constitutional claims on federal habeas. Finally, this part examines whether this indirect approach to limiting habeas leads to rational and desirable outcomes as a matter of public policy.

Part II then turns to the primary question presented in this Article: how a Congress intent upon directly curtailing habeas by narrowing the substantive scope of the writ might proceed. Toward that end, Part II examines the possible approaches Congress might take in curtailing the scope of the writ and concludes that Congress would best be served by declaring certain federal constitutional claims to be outside of habeas review.

In deciding which claims to exclude from habeas, Congress should proceed with a clear vision of the purpose and role of the federal writ of habeas corpus in modern postconviction proceedings. Accordingly, Part II canvasses the five theories of habeas most often advanced in the academic literature and in Supreme Court opinions. This survey finds that the purpose of the writ is to guard against fundamental unfairness ${ }^{9}$ and that the writ largely functions as an extension of the state appellate review process. ${ }^{10}$ Part II thus recommends that Congress decide which claims to include in federal habeas review by asking which claims are so vital to assuring fundamentally fair

its analysis that policymakers have concluded that a narrower substantive writ is in the public interest.

9. See, e.g., Teague v. Lane, 489 U.S. 288, 314 (1989) (plurality) (holding that the requirement that a petit jury consist of a fair cross-section of the community was not the sort of "absolute prerequisite to fundamental fairness" that can be applied retroactively on habeas); see also infra Part II.B.5 (discussing the "fundamental fairness" rationale). Academics agree. See, e.g., Barry Friedman, Failed Enterprise: The Supreme Court's Habeas Reform, 83 CAL. L. REV. 485, 488 (1995) [hereinafter Friedman, Failed Enterprise] ("[H]abeas clearly has something to do with [fairness] matters such as vindicating constitutional rights ....").

10. See McCord, supra note 5, at 838 ("There were then, and still are, many significant areas of habeas jurisprudence that can be explained by the appellate review vision ...."). 
criminal proceedings that they must be reheard on federal habeas notwithstanding the prior opportunity to litigate them in the state courts. This model highlights the salient fact that Congress, when reshaping the writ of habeas, is only deciding which federal constitutional claims may be relitigated on habeas. That is because the state courts reviewing a conviction on direct appeal or in state collateral proceedings will continue to have jurisdiction over all federal constitutional claims, regardless of their cognizability on habeas, and because federal habeas courts will continue to have "backstop" jurisdiction over any federal constitutional claims that a prisoner did not have an adequate opportunity to litigate in the state courts.

Part III explores what a writ based on this combined modelwhich in essence gives content to the concept of fundamental fairness by reference to the appellate function of habeas-would look like. The part starts by articulating the standard that could guide legislators in selecting the federal constitutional claims that prisoners would be able to relitigate on habeas. Part III then briefly surveys the federal constitutional rights that would likely be essential to secure "fundamental fairness," as that term is newly defined, thereby providing a brief catalogue of the constitutional claims that would fall within the scope of this new statutory writ.

With the task of redefining the substantive scope completed, Part IV revisits the procedural and quasi-procedural doctrines that currently limit the availability of the writ. Because these doctrines were created in large part to screen out claims, there is less need for them once the substantive scope of the habeas is narrowed to the subset of constitutional claims deemed sufficiently important and fundamental to warrant relitigation in the federal courts. Consequently, this part examines these procedural and quasi-procedural doctrines to see how they could be modified or eliminated to accommodate a narrower substantive writ.

Part V briefly recounts the key points to be considered in assessing whether this newly constituted writ would accord with the Suspension Clause of the Constitution, which provides that "[t]he Privilege of the Writ of Habeas Corpus shall not be suspended, unless when in Cases of Rebellion or Invasion the public Safety may require it." 11 Although Congress, in amending the substantive scope of the writ, is not (as the courts are) bound by the current statutory lan-

11. U.S. CONST. art. I, § 9, cl. 2. 
guage of the writ, Congress's discretion to fashion its normative vision of the statutory writ is still bounded by the Constitution. This final part therefore evaluates the constitutionality of the substantively narrower writ developed in this Article.

\section{THE PROCEDURAL THICKET}

Although section 2254(a) explicitly states that the federal writ of habeas corpus is available to state prisoners held "in custody in violation of the Constitution or laws or treaties of the United States," 12 that provision may give an inaccurate picture of the practical availability of the writ today. That is because the Supreme Court has established several doctrines that regulate habeas procedure or otherwise affect the legal or practical availability of the writ. ${ }^{13}$ It is only by understanding these doctrines and how they interrelate that one can accurately assess the actual scope of the writ today or understand why some policymakers would support a more explicit and direct curtailment of the scope of habeas. Familiarity with these doctrines as currently constituted also provides a helpful backdrop for evaluating how they should be modified if Congress expressly narrows the substantive scope of the writ. $^{14}$

The exhaustion doctrine, the oldest of the procedural barriers, ${ }^{15}$ requires a state prisoner in most cases to present the substance of any federal constitutional claim to the state courts before it may be raised in a federal habeas petition. ${ }^{16}$ This doctrine seeks "to minimize fric-

\footnotetext{
12. 28 U.S.C. $§ 2254($ a) (Supp. III 1997).

13. See supra text accompanying note 3 .

14. A fuller discussion of how these procedural doctrines should be modified in light of the proposals in this Article is contained infra at Part IV.

15. The Court first established a discretionary exhaustion doctrine in 1886. See Royall, 117 U.S. 241, 251 (1886) (holding that the statute directing federal courts to hear habeas cases "does not deprive the court of discretion as to the time and mode in which it will exert to powers conferred upon it"). Congress codified a mandatory exhaustion requirement when it amended $\S$ 2254 in 1948. See Act of June 25, 1948, Pub. L. No. 773, ch. 153, 62 Stat. 869, 967.

16. See Anderson v. Harless, 459 U.S. 4, 6 (1982) (holding that habeas petitioners must present their claims to a state court before requesting federal habeas review); Picard v. Connor, 404 U.S. 270, 275 (1971) ("It is has been settled since Ex parte Royall that a state prisoner must normally exhaust available state judicial remedies before a federal court will entertain his petition for habeas corpus." (citation omitted)). Although exhaustion is technically an equitable doctrine (that is, a prisoner's failure to exhaust state remedies does not rob the federal courts of jurisdiction), "there is a strong presumption in favor of requiring the prisoner to pursue his available state remedies." Granberry v. Greer, 481 U.S. 129, 131 (1987); accord Rose v. Lundy, 455 U.S. 509, 515 (1982) ("[S]tate remedies must be exhausted except in unusual circumstances.”).
} 
tion between our federal and state systems of justice by allowing the State an initial opportunity to pass upon and correct alleged violations of prisoners' federal rights." ${ }^{17}$ Given this purpose, a prisoner need not "exhaust his state remedies" if "there is an absence of available State corrective process" or if "circumstances exist that render such process ineffective to protect the rights of the [habeas] applicant." ${ }^{18}$

At first blush, a failure to exhaust state remedies would appear easy to fix: return to state court, present the unexhausted federal claims to the state tribunal, and raise the now-exhausted claims in a second federal habeas petition. The federal exhaustion doctrine would not stand in the way. However, another doctrine-the procedural default doctrine ${ }^{19}$ - would, because a prisoner returning to state court to raise a new claim would probably be denied a ruling on the merits of his claim by the state's procedural rules, which usually require criminal defendants to raise all of their claims at once at the earliest possible time and which allow proceedings to be reopened only for a short time after the state courts issue their rulings. ${ }^{20}$ A prisoner returning to state court years after he is convicted in order to exhaust a federal claim is unlikely to be able to satisfy these state procedural rules. ${ }^{21}$ The penalty for failing to adhere to those rules is the

A state prisoner does not have to present his claims to state courts more than once, however, even if there exist further avenues of state court review. As the Court stated, "once the state courts have ruled upon a claim, it is not necessary for a petitioner 'to ask the state for collateral review, based upon the same evidence and issues already decided by direct review." Castille v. Peoples, 489 U.S. 346, 350 (1989) (quoting Brown v. Allen, 344 U.S. 443, 447 (1953)).

17. Duckworth v. Serrano, 454 U.S. 1, 3 (1981) (per curiam).

18. 28 U.S.C. $\$ 2254$ (b)(1)(B) (Supp. III 1997); see also Duckworth, 454 U.S. at 3 (explaining that a prisoner need not exhaust his state remedies if "there is no opportunity to obtain redress in state court or if the corrective process is so clearly deficient as to render futile any effort to obtain relief"). A federal court may also waive the exhaustion requirement if there are grounds to deny the habeas petition on its merits. See 28 U.S.C. $§ 2254($ b)(2) ("An application for a writ of habeas corpus may be denied on the merits, notwithstanding the failure of the applicant to exhaust the remedies available in the courts of the State.").

19. Wainwright v. Sykes, 433 U.S. 72 (1977), established the modern procedural default doctrine. See id. at 87-91 (holding that federal habeas review is unavailable for issues that were barred from consideration in state court because of state procedural rules); see also infra note 23 and accompanying text.

20. See Herrera v. Collins, 506 U.S. 390, 410-11 \& nn.8-11 (1993) (listing time limits that apply in various states).

21. A 1995 study by the Department of Justice found that the average time between a defendant's conviction in state court and the filing of his federal habeas petition was 1802 days-or nearly five years. See Roger A. HAnson \& Henry W.K. Daley, Bureau of Justice Statistics, Federal Habeas Corpus Review: Challenging State Court Criminal CONVICTIONS 12 (1995). 
state court's refusal to hear the merits of the prisoner's claim. Of course, the petitioner in this situation has technically exhausted his state remedies because there are no further state remedies to exhaust-they are all foreclosed to him. ${ }^{22}$

But federal courts entertaining habeas petitions are required by the procedural default doctrine to honor state procedural rules. Consequently, if a state court finds that the prisoner did not comply with a state procedural rule and accordingly refuses to reach the merits of her federal constitutional claim, that claim is considered "procedurally defaulted" and may be reexamined by a federal habeas court only under certain circumstances. ${ }^{23}$

In the 1960s, those circumstances were numerous. In fact, under the Supreme Court's 1963 decision in Fay v. Noia, ${ }^{24}$ federal courts were all but obligated to reach the merits of federal constitutional claims notwithstanding violation of state procedural rules, except when the habeas petitioner had "deliberately sought to subvert or evade the orderly adjudication of his federal defenses in the state courts." ${ }^{25}$ The Court has subsequently narrowed the conditions under which a federal court may disregard a state's finding that a prisoner failed to comply with state procedural rules. Fay has been overruled, ${ }^{26}$

22. See Coleman v. Thompson, 501 U.S. 722,732 (1991) ("A habeas petitioner who has defaulted his federal claims in state court meets the technical requirements for exhaustion; there are no state remedies any longer 'available' to him."); see also Engle v. Isaac, 456 U.S. 107, 125 26 n.28 (1982) (noting that a petitioner's claims can be exhausted when state procedural bars prevent consideration of some claims that could have been raised).

23. On direct review of a state conviction, the Supreme Court does not have the jurisdiction to hear a federal constitutional claim if the state court determines that the prisoner failed to meet state procedural rules and refuses to reach the merits of her claim. That is because the state procedural bar constitutes an "adequate" and "independent" state ground for the judgment, such that any holding of the Supreme Court on the merits of the constitutional claim would be "advisory" (and hence beyond the Court's power under Article III), because it would not affect the judgment of conviction. See Wainwright, 433 U.S. at 81 (observing that "it is a well-established principle of federalism that a state decision resting on an adequate foundation of state substantive law is immune from review in the federal courts" and holding the same for state procedural law); see also Harris v. Reed, 489 U.S. 255, 260-61 (1989) (discussing the doctrine by which the Court disclaims authority to review state court judgments that rest on an independent and adequate nonfederal ground); Fox Film Corp. v. Muller, 296 U.S. 207, 210 (1935) (noting that federal courts have no jurisdiction to review state court judgments supportable on an independent, nonfederal ground); Murdock v. City of Memphis, 87 U.S. (20 Wall.) 590, 63436 (1874) (holding that habeas review is only appropriate where there is a federal question the answer to which would have an impact on the final judgment in the case).

24. 372 U.S. 391 (1963).

25. Id. at 433 .

26. See Coleman, 501 U.S. at 750-51 (overruling Fay's holding that federal courts can hear issues that were excluded from state court proceedings based on independent and adequate 
and a federal court hearing a habeas petition today may not reach the merits of a procedurally defaulted claim unless the petitioner can either show "cause for the noncompliance [with the state procedural rule] and some showing of actual prejudice resulting from the alleged constitutional violation" ${ }^{27}$ or can demonstrate "that failure to consider [his federal] claims will result in a fundamental miscarriage of justice.", 28

These exceptions have been defined very narrowly. A "fundamental miscarriage of justice" has been held to exist only "in an extraordinary case, where a constitutional violation has probably resulted in the conviction of one who is actually innocent., ${ }^{29}$ The Court has frankly acknowledged that this "more like than not" ${ }^{\text {"30 }}$ standard for innocence "is a very narrow exception" 31 and that "habeas corpus petitions that advance a substantial claim of actual innocence are extremely rare." 32

The "cause" and "prejudice" standard is similarly narrow. Thus far, the Court has not yet defined precisely how a habeas petitioner establishes "prejudice." ${ }^{33}$ The Court has, however, found that a petitioner may establish "cause" for noncompliance with state procedural rules by showing either that his counsel was constitutionally ineffective under the Sixth Amendment ${ }^{34}$ that "the factual or legal basis for a claim was not reasonably available to counsel, ${ }^{, 35}$ or that state offi-

state procedural grounds).

27. Wainwright, 433 U.S. at 84.

28. Coleman, 501 U.S. at 750 (quoting Murray v. Carrier, 477 U.S. 478 (1986)).

29. Murray, 477 U.S. at 496.

30. Schlup v. Delo, 513 U.S. 298, 327 (1995).

31. Sawyer v. Whitley, 505 U.S. 333, 341 (1992). In the context of a capital sentencing, the Court held that a defendant seeking habeas review of aggravating circumstances allowing imposition of the death penalty must establish that "no reasonable juror would find him eligible for the death penalty." Id. at 348 (emphasis added). It is not enough to prove that no jury would have imposed the death penalty after weighing the factors making the defendant eligible for the death penalty against those mitigating against it. See id. at 345-46.

32. Schlup, 513 U.S. at 321.

33. See JAmes S. Liebman \& Randy Hertz, Federal Habeas Corpus Practice ANd Procedure 1108 (3d ed. 1998) ("The Supreme Court has not yet provided any precise definition of the 'prejudice' half of the 'cause and prejudice' exception to the procedural default doctrine."). This is particularly troublesome because, as the Liebman treatise goes on to explain, there are several possible definitions of "prejudice." See id. at 1109-11.

34. See Murray, 477 U.S. at 488.

35. Id.; Reed v. Ross, 468 U.S. 1, 14 (1984) ("[T]he failure of counsel to raise a constitutional issue reasonably unknown to him is one situation in which the [cause] requirement is met."); see also Engle v. Isaac, 456 U.S. 107, 130-34 (1982) (rejecting defendant's habeas petition on the grounds that the legal basis of his constitutional claim was available at the time of his 
cials somehow interfered with the petitioner's ability to comply with the state procedural rule. ${ }^{36}$

As a practical matter, these hurdles are difficult to overcome. With regard to the first exception, the Court has made it clear that "[a]ttorney error short of ineffective assistance of counsel does not constitute cause for a procedural default, ${ }^{, 37}$ and the Court's standard for constitutional ineffectiveness under Strickland $v$. Washington ${ }^{38}$ is a notoriously onerous one. ${ }^{39}$ Few litigants will therefore be able to use this basis for establishing cause. In addition, because the constitutional right to effective assistance of counsel applies only during trial and the first appeal of right, ${ }^{40}$ an attorney's negligence in failing to raise a claim during state postconviction review or in federal habeas proceedings can never constitute "cause"- even though some constitutional claims cannot be raised at any prior time. ${ }^{41}$

trial).

36. See Brown v. Allen, 344 U.S. 443, 486 (1953); see also Amadeo v. Zant, 486 U.S. 214, 217-22 (1988) (holding that the district attorney's failure to turn over a memorandum detailing discriminatory practices in jury selection constituted "cause" that excused the petitioner's previous failure to raise a challenge to the composition of the jury).

37. Reed, 477 U.S. at 492.

38. 466 U.S. 668, 686 (1984) ("The benchmark for judging any claim of ineffectiveness must be whether counsel's conduct so undermined the proper functioning of the adversarial process that the trial cannot be relied on as having produced a just result.").

39. See, e.g., Donald A. Dripps, Ineffective Assistance of Counsel: The Case for an Ex Ante Parity Standard, 88 J. CRIM. L. \& CRIMINOLOGY 242, 243 (1997) ("Strickland's critics rightly claim that the current right-to-counsel doctrine is dysfunctional."); William S. Geimer, A Decade of Strickland's Tin Horn: Doctrinal and Practical Undermining of the Right to Counsel, 4 WM. \& MARY BILL RTS. J. 91, 148 (1995) (“[M]any instances of dreadful lawyering are found to be acceptable [under Strickland].").

40. The Supreme Court recognized a due process right to counsel during a criminal defendant's first appeal of right in Douglas v. California, 372 U.S. 353 (1963). That right encompasses the right to competent counsel. See Evitts v. Lucey, 469 U.S. 387, 396 (1985) (“A first appeal as of right ... is not adjudicated in accord with due process if the appellant does not have the effective assistance of an attorney."). The Court has declined to extend any constitutional right to counsel to discretionary appeals. See Ross v. Moffitt, 417 U.S. 600, 610 (1974). It is doubtful that any constitutional right exists for collateral review either. See Pennsylvania v. Finley, 481 U.S. 551, 555 (1987) ("We have never held that prisoners have a constitutional right to counsel when mounting collateral attacks upon their convictions... and we decline to so hold today. Our cases establish that the right to appointed counsel extends to the first appeal of right, and no further."). Because "the right to effective assistance of counsel is dependent on the right to counsel itself," Evitts, 469 U.S. at 397 n.7, petitioners whose counsel is ineffective on discretionary or collateral review are unable to establish "cause" on the basis of constitutional ineffectiveness.

41. A defendant whose appellate counsel errs on direct appeal, for example, cannot usually raise an ineffective assistance claim until postconviction review begins and the defendant has new (or no) counsel. 
The second exception will also rarely be available because any constitutional claim sufficiently novel to meet the "cause" standard is also likely to be considered a "new rule" under the Supreme Court's nonretroactivity doctrine, which does not permit defendants to avail themselves of new rules of constitutional criminal procedure, that is, those handed down after their convictions become final. ${ }^{42}$ This leaves the third exception as the sole viable means of establishing "cause," but cases of state interference with an attorney's ability to comply with state procedural rules are both unusual and difficult to prove. ${ }^{43}$

The Supreme Court's 1982 decision in Rose v. Lundy ${ }^{44}$ further complicates the interplay between the doctrines of exhaustion, procedural default, and the doctrine of abusive petitions, which usually requires a habeas petitioner to bring all of his claims in his first habeas petition. ${ }^{45}$ In Rose, the Court adopted a rule of "total exhaustion": a habeas petition containing both exhausted claims and unexhausted claims must be dismissed in its entirely. ${ }^{46}$ This rule forces the habeas petitioner into a difficult decision-withdraw the entire petition, try to exhaust the unexhausted claims, and return to federal court months or years later; or, proceed solely with the exhausted claims by dropping the unexhausted claims, in the hopes of exhausting them

42. See Teague v. Lane, 489 U.S. 288, 305-16 (1989) (plurality). For a more complete discussion of Teague, see infra Part II.A.3. Cases where the factual basis of a claim is unavailable will usually fall into one of two camps-when the defendant's counsel fails to find the facts (in which case the first "cause" exception applies) or when the state interferes with the defendant's ability to find the facts (in which case the final "state interference" exception applies).

43. They are not unheard of, however. In Amadeo v. Zant, 486 U.S. 214 (1988), for example, the Supreme Court found that a capital defendant established "cause" for failing to raise a claim of grand jury discrimination because the state had failed to hand over a memorandum instructing the jury commissioners on how to select grand jurors so as to ensure the underrepresentation of minority jurors. See id. at 217-22. Claims under Brady v. Maryland, 373 U.S. 83 (1963), similarly involve suppression of information by state officials. Because Brady claims by definition involve a prosecutor's failure to give the defendant exculpatory evidence in the state's possession, however, a Brady violation will not usually relate to a habeas petitioner's failure to meet a procedural bar.

44. 455 U.S. 509 (1982).

45. See McCleskey v. Zant, 499 U.S. 467 (1991). In McCleskey, the Supreme Court adopted for abusive petitions the same standard that governs procedural defaults. See id. at 493 ("[T]he standard for excusing a failure to raise a claim at the appropriate time should be the same in both [the procedural default and abusive petition] contexts."). As a result, the "cause" and "prejudice" and "miscarriage of justice" standards discussed above, see supra text accompanying notes 27-36, controlled. Amendments to the habeas statutes pursuant to the Antiterrorism and Effective Death Penalty Act of 1996 ("AEDPA") may have changed the parity of doctrine. See infra note 204.

46. See Rose, 455 U.S. at 518-19 (plurality). 
later. ${ }^{47}$ A petitioner opting to withdraw the petition entirely delays any relief and may likely miss the newly enacted, one-year limitations period for filing habeas petitions, ${ }^{48}$ while a petitioner opting to proceed solely with his exhausted claims "would risk forfeited consideration of his unexhausted claims in federal court" when he files a second habeas petition containing the later-exhausted claims. ${ }^{49}$

As this brief discussion illustrates, the interaction of the doctrines of exhaustion, procedural default, and abusive petitions has created a very elaborate set of procedural hurdles that must be negotiated before a state prisoner's claims may be heard by a federal court on habeas. To be sure, none of these doctrines technically restricts the substantive scope of habeas, because any petitioner able enough to navigate these procedural straits successfully is entitled to review of the merits of her federal constitutional claims. In practical terms, however, these procedural hurdles end up precluding or greatly delaying resolution of the merits in a substantial number of cases.

There is good reason to believe that this approach to curtailing habeas is flawed. To begin with, these procedural doctrines are quite complex. ${ }^{50}$ This complexity is especially hard on the vast majority of

47. See id. at 520-21 (discussing the two options that the "total exhaustion" rule leaves for habeas petitioners).

48. See 28 U.S.C. § 2244(d)(1) (Supp. III 1997) (“A 1-year period of limitation shall apply to an application for a writ of habeas corpus by a person in custody pursuant to the judgment of a State court."). A petitioner in this situation will not, however, be deemed to be filing a "second or successive petition" within the meaning of pre-AEDPA, and possibly post-AEDPA, law when he returns to federal court with a new habeas petition containing his newly exhausted claims. See Slack v. McDaniel, 2000 WL 478879 (U.S. Apr. 26, 2000). The Court reasoned that it is more appropriate "to treat the initial mixed petition as though it had not been filed, subject to whatever conditions the [District] Court [dismissing the petition] attaches to the dismissal." Id. at *8. Prior to Slack, the lower federal courts had been split on this issue. Compare Slack v. McDaniel, No. CV-N-95, 194-DWH (D. Nev. Mar. 31, 1998) (unpublished opinion), reprinted in 1999 WL 297747, at *152aa, with Carlson v. Pitcher, 137 F.3d 416, 418-20 (6th Cir. 1998) (holding that a habeas petitioner whose first petition was dismissed for failure to exhaust state remedies would not be barred by AEDPA's "second or successive" petition rule from refiling after exhaustion), and McWilliams v. Colorado, 121 F.3d 573, 575 (10th Cir. 1997) (same), and In re Gasery, 116 F.3d 1051, 1051-52 (5th Cir. 1997) (same), and Christy v. Horn, 115 F.3d 201, 208 (3d Cir. 1997) (same), and Dickinson v. Maine, 101 F.3d 791, 791 (1st Cir. 1996) (same), and Camarano v. Irvin, 98 F.3d 44, 45-46 (2d Cir. 1996) (same).

49. Rose, 455 U.S. at 520 (plurality).

50. See Baird, supra note 5, at 311 (finding these procedural doctrines "technical and cumbersome"); Friedman, Two Habeas, supra note 1, at 253, 273 (claiming that "the rules governing access to habeas review have become hopelessly ... confused" and constitute a "widely acclaimed muddle"); Joseph L. Hoffmann \& William J. Stuntz, Habeas After the Revolution, 1993 SuP. CT. REV. 65, 109, 112 (1994) (noting that "[c]urrent habeas doctrine is plagued by its complexity" and "has no messier thicket than the law of defaulted claims"); Jordan Steiker, Re- 
habeas petitioners, who do not have counsel. ${ }^{51}$ In 1995 , for example, $58.6 \%$ of the habeas petitions filed by state prisoners in federal district courts were dismissed on procedural grounds. ${ }^{52}$ A similar study of federal habeas petitions filed by state prisoners and disposed of in 1992 found that on average, $65 \%$ of the claims raised in their petitions were dismissed on procedural grounds $-57 \%$ of the claims for failure to exhaust and another $12 \%$ of the claims for procedural default. ${ }^{53}$

These results are troubling for two reasons. First, these procedural devices reduce the availability of habeas review, but they do so indirectly and without the legal and political debate that would occur if the scope of claims cognizable on habeas were narrowed directly. Second, and more troubling, is that these procedural doctrines can fit together in ways that effectively block any review of an inmate's substantive claims, ${ }^{54}$ and they may do so on a seemingly irrational or unfair basis. For example, two petitioners who, through no fault of their own, defaulted claims because they could not discover the facts necessary to establish those claims would be treated differently depending on whether the state or some other party had hidden the facts. In effect, these procedural doctrines distinguish between defendants differently based on each defendant's respective ability to navigate the procedural thicket, which has little or no bearing on that defendant's substantive entitlement to relief.

structuring Post-Conviction Review of Federal Constitutional Claims Raised by State Prisoners: Confronting the New Face of Excessive Proceduralism, 1998 U. CHI. LEGAL F. 315, 316 [hereinafter Steiker, Restructuring] (“[O]ne can lament the high cost of extraordinarily intricate procedural litigation in criminal cases."); Daniel B. Yeager, Categorical and Individualized RightsOrdering on Federal Habeas Corpus, 51 WASH. \& LEE L. REV. 669, 680 (1994) ("Habeas certainly has become a 'confused patchwork' of 'petty procedural barriers." (quoting Brecht v. Abrahamson, 507 U.S. 619, 649 (1993) (White, J., dissenting) and Coleman v. Thompson, 501 U.S. 722, 759 (1991) (Blackmun, J., dissenting))).

51. A 1995 Justice Department study found that $93 \%$ of the habeas corpus cases it sampled involved a prisoner proceeding without counsel. See HANSON \& DALEY, supra note 21, at 14.

52. See John Scalia, Bureau of Justice Statistics, Prisoner Petitions in the FEDERAL COURTS 1980-1996, at 6 (1997).

53. See HANSON \& DALEY, supra note 21, at 17. These statistics are not surprising, since state prisoners have no constitutional right to counsel on federal habeas. See supra note 40. Persons sentenced to death have a statutory right to counsel in federal habeas proceedings, see 21 U.S.C. $\$ 848(q)(4)(B)(1994)$, but, in all other cases, counsel may be assigned to "financially eligible" persons only if "the court determines that the interests of justice so require," 18 U.S.C. $\S$ 3006A(a)(2) (1994).

54. See Baird, supra note 5, at 336 ("In sum, the Court has narrowed the availability of federal habeas corpus by three primary means: retroactive application [of new rules], procedural default, and harmless error."). For a more detailed explanation of how the doctrines fit together to block review, see supra text accompanying notes 19-49. 
In addition to these procedural doctrines that act as threshold barriers to federal habeas review, the Court and Congress have also fashioned what might be called quasi-procedural mechanisms that have the effect of reducing the likelihood that a federal habeas petition will succeed on its merits once it is heard. Until recently, a federal court reviewing a habeas petition would defer to the state courts' findings of fact but would review de novo any purely legal questions or mixed questions of law and fact. ${ }^{55}$ In 1996, Congress ostensibly changed the second of these well-settled rules by foreclosing habeas relief unless the state court's decision is "contrary to, or involved an unreasonable application of, clearly established Federal law, as determined by the Supreme Court of the United States. ${ }^{, 56}$ This Term, the Supreme Court interpreted this new language to mean just what it says-that federal habeas courts must defer to reasonable interpretations of federal law made by state courts. ${ }^{57}$ More specifically, the

55. During this period, the factual findings of the state courts were "presumed . . correct." 28 U.S.C. $\$ 2254$ (d) (1994) (noting presumption, but listing eight circumstances when that presumption could be rebutted); see also Thompson v. Keohane, 516 U.S. 99, 107-08 (1995) ("In [federal habeas corpus] proceedings, $§ 2254$ (d) declares, state-court determinations of 'a factual issue' 'shall be presumed to be correct' absent one of the enumerated exceptions." (quoting 28 U.S.C. $\$ 2254(d)$ ); Townsend v. Sain, 372 U.S. 293, 313 (1963) (setting forth most of the criteria ultimately adopted by Congress in $\S 2254(\mathrm{~d})$ ). By contrast, the holdings of state courts on purely legal questions, or mixed questions of law and fact, were reviewed de novo. See Thompson, 516 U.S. at 112-13; Miller v. Fenton, 474 U.S. 104, 112 (1985); Townsend, 372 U.S. at 318 ("Although the district judge may ... defer to the state court's findings of fact, he may not defer to its findings of law."). Three Justices of the Supreme Court questioned independent review of mixed questions in Wright v. West, 505 U.S. 277 (1992). See id. at 288-97 (plurality opinion of Thomas, J.).

56. 28 U.S.C. $\$ 2254(d)(1)$ (Supp. III 1997). The 1996 amendments retained the previous rule of deference to state findings of fact. See id. § 2254(d)(2) (permitting an award of habeas relief only if the state court's decision was "based on an unreasonable determination of the facts in light of the evidence presented in the State court proceeding").

57. See Williams v. Taylor, 120 S. Ct. 1495 (2000). The decision resolved a deep split among the federal courts on the meaning of this language. Compare Neelley v. Nagle, 138 F.3d 917, 924 (11th Cir. 1998) (interpreting the language to require de novo review for pure legal questions and deferential review for mixed questions of law and fact), cert. denied, 119 S. Ct. 811 (1999), and Lindh v. Murphy, 96 F.3d 856, 870 (7th Cir. 1996) (same), rev'd on other grounds, 521 U.S. 320 (1997), and Drinkard v. Johnson, 97 F.3d 751, $767-69$ (5th Cir. 1996) (same), cert. denied, 520 U.S. 1107 (1997), with Matteo v. Superintendent, Sci Albion, 171 F.3d 877, 885-89 (3d Cir.) (interpreting the language to require courts to apply "contrary to" language when the Supreme Court has prescribed a governing rule and to apply the "unreasonable application" language where no such rule exists), cert. denied, 120 S. Ct. 73 (1999), and Long v. Humphrey, 184 F.3d 758, 759-61 (8th Cir. 1999) (same), and O'Brien v. Dubois, 145 F.3d 16, 20-26 (1st Cir. 1998) (same), with Davis v. Kramer, 167 F.3d 494, 500 \& n.8 (9th Cir. 1999) (interpreting the language to require courts to apply both types of analysis to cases, depending on how much they diverge from relevant Supreme Court precedent), vacated on other grounds, 120 S. Ct. 1001 (2000), and Green v. French, 143 F.3d 865, 869-73 (4th Cir. 1998) (employing a similar analysis), with Hall v. 
Court held that a state court decision is "contrary to . . clearly established Federal law" only "if the state court arrives at a conclusion opposite to that reached by [the Supreme Court] on a question of law or if the state court decides a case differently from [the Court] has on a set of materially indistinguishable facts. ${ }^{, 58}$ Similarly, a state court decision involves an "unreasonable application of, clearly established Federal law" only if "the state court's application ... was objectively unreasonable." 59 In making this determination, a federal habeas court's "conclu[sion] in its independent judgment that the relevant state court decision applied clearly established federal law erroneously or incorrectly" is not enough-the state court's "application must also be unreasonable."

Even if a federal court reaches the merits of a claim raised on habeas and determines that the state court erred in resolving that claim, a habeas petitioner is not automatically entitled to relief, such as a new trial or resentencing. ${ }^{61}$ Instead, it must usually be established that the error affected the verdict. The Supreme Court has held that some errors are so egregious that they are presumed to be harmful and accordingly always require reversal. These "structural errors" include the total deprivation of counsel at trial, ${ }^{62}$ trial before a partial judge, ${ }^{63}$ an erroneous "beyond a reasonable doubt" instruction, ${ }^{64}$ dep-

Washington, 106 F.3d 742, 748 (7th Cir.) (applying de novo review to all legal questions and to mixed questions of law and fact), cert. denied, 118 S. Ct. 264 (1997).

For a comprehensive discussion of this disagreement, see Alan K. Chen, Shadow Law: Reasonable Unreasonableness, Habeas Theory, and the Nature of Legal Rules, 2 BUFF. CRIM. L. REV. 535, 552-93 (1999).

58. Williams, $120 \mathrm{~S}$. Ct. at 1523.

59. Id. at 1521.

60. Id. at 1522. Justice Stevens, along with Justices Souter, Ginsburg, and Breyer, disagreed with the majority's gloss on the 1996 amendments. In their view, the language "express[ed] a "mood" that directed "federal judges to attend with the utmost care to state-court decisions, including all of the reasons supporting their decisions, before concluding that those proceedings were infected by constitutional error ...." Id. at 1509 (opinion of Stevens, J.). "Whatever 'deference' Congress had in mind," Justice Stevens wrote, "it surely is not a requirement that federal courts actually defer to a state-court application of the federal law that is, in the independent judgment of the federal court, in error." Id. at 1509-10. Such a rule would, in his view, have trod upon "the federal courts' independent responsibility ... to interpret federal law." Id. at 1505 .

61. See, e.g., id. at 1505 ("It is, of course, well settled that the fact that constitutional error occurred in the proceedings that led to a state-court conviction may not alone be sufficient reason for concluding that a prisoner is entitled to the remedy of habeas corpus.").

62. See Gideon v. Wainwright, 372 U.S. 335, 342-45 (1963).

63. See Tumey v. Ohio, 273 U.S. 510, 522 (1927).

64. See Sullivan v. Louisiana, 508 U.S. 275, $277-82$ (1993). 
rivation of the right to self-representation at trial, ${ }^{65}$ deprivation of the right to a public trial, ${ }^{66}$ and unlawful exclusion of members of the defendant's race from a grand jury. ${ }^{67}$ Most other constitutional errors are considered "trial errors."

On direct appeal, a criminal defendant who successfully establishes that her constitutional trial rights were violated is entitled to relief unless the state can prove "beyond a reasonable doubt that the [constitutional trial] error complained of did not contribute to the verdict obtained." ${ }^{\circ 9}$ Until 1993, it was generally accepted that the rules for evaluating whether a trial error was harmless on direct appeal also applied on federal habeas. ${ }^{70}$ In Brecht v. Abrahamson, ${ }^{71}$ however, the Supreme Court held that a habeas petitioner must prove that the constitutional error "'had substantial and injurious effect or influence in determining the jury's verdict'" before he might obtain relief, ${ }^{72}$ except that, as later indicated by O'Neal $v$. McAninch, ${ }^{73}$ any

65. See McKaskle v. Wiggins, 465 U.S. 168, 177-78 n.8 (1984).

66. See Waller v. Georgia, 467 U.S. 39, 44-48 (1984).

67. See Vasquez v. Hillery, 474 U.S. 254, 260-64 (1986). The admission of an involuntary confession was also considered grounds for automatic reversal of a conviction until 1991. Compare Payne v. Arkansas, 356 U.S. 560, 567-68 (1958), with Arizona v. Fulminante, 499 U.S. 279, 309-12 (1991).

68. See Fulminante, 499 U.S. at 306 ("[T]he Court ... has recognized that most constitutional errors can be harmless.").

69. Chapman v. California, 386 U.S. 18, 24 (1967).

70. See, e.g., Yates v. Evatt, 500 U.S. 391, $402-07$ (1991) (applying the Chapman standard on federal habeas); Rose v. Clark, 478 U.S. 570, 576-79 (1986) (same); Milton v. Wainwright, 407 U.S. 371, 377-78 (1972) (same); Anderson v. Nelson, 390 U.S. 523, 525 (1968) (per curiam) (same).

71. 507 U.S. 619 (1993).

72. Id. at 631 (quoting Kotteakos v. United States, 328 U.S. 750,776 (1946)); see also id. at 637 (ruling that "habeas petitioners ... are not entitled to habeas relief based on trial error unless they can establish that it resulted in 'actual prejudice"" (quoting United States v. Lane, 474 U.S. 438, 449 (1986)) (emphasis added)). The Brecht standard is identical to the standard announced by the Supreme Court for reviewing nonconstitutional errors on direct review of federal convictions. See Kotteakos, 328 U.S. at 776 (announcing that the test for considering a postconviction variance postconviction is whether the error "had substantial and injurious effect on the jury's verdict"). The Kotteakos standard itself was derived from a federal criminal statute and a rule of federal criminal procedure. See 28 U.S.C. § 2111 (1994) ("On the hearing of any appeal or writ of certiorari in any case, the court shall give judgment after an examination of the record without regard to errors or defects which do not affect the substantial rights of the parties."); FED. R. CRIM. P. 52(a) (“Any error, defect, irregularity or variance which does not affect substantial rights shall be disregarded.").

The Court in Brecht retained the rule of automatic reversal for structural errors. See Brecht, 507 U.S. at 629-30. It also noted that its new "harmless error" standard might apply in some situations not involving structural errors. More specifically, the Court recognized the

possibility that in an unusual case, a deliberate and especially egregious error of the 
uncertainty about whether a petitioner meets this standard is to be resolved in favor of granting relief. ${ }^{74}$ By increasing the threshold for obtaining relief, the Brecht standard-like the other doctrines discussed in this part-leaves the substantive scope of habeas intact while making habeas relief less available. ${ }^{75}$

As this part illustrates, judges and legislators intent on curtailing the availability of federal habeas corpus have two options. They can erect procedural and quasi-procedural barriers that, while technically leaving the substantive scope of the writ untouched, nevertheless render habeas relief beyond the reach of most state prisoners, particularly when so many of them proceed pro se. ${ }^{76}$ Alternatively, those intent on restricting the writ may choose to narrow the substantive scope of the writ explicitly and may thereby more actively (and rationally) control which cases are relitigated on habeas. This Article now explores various ways of doing so.

\section{NARROWING THE SUBSTANTIVE SCOPE}

When explicitly considering narrowing the scope of the federal habeas writ, it is important to be aware of the broader considerations

trial type, or one that is combined with a pattern of prosecutorial misconduct, might so infect the integrity of the proceeding as to warrant the grant of habeas relief, even if it did not influence the jury's verdict.

Id. at 638 n.9.

73. 513 U.S. 432 (1995).

74. See id. at 436 ("When a federal judge in a habeas proceeding is in grave doubt about whether a trial error of federal law had 'substantial and injurious effect or influence in determining the jury's verdict,' that error is not harmless." (quoting O'Neal v. Morris, 3 F.3d 143, 145 (1993) (quoting Brecht, 507 U.S. at 627))).

The federal courts of appeals are currently divided on whether Chapman still applies on habeas in cases where the federal court is the first court to review the claim (that is, where the state courts have not had an opportunity to review it). One circuit has held that Chapman should apply in this situation. See Orndorff v. Lockhart, 998 F.2d 1426, 1430 (8th Cir. 1993). The majority of remaining circuits have held that Brecht applies in this situation. See Gilliam v. Mitchell, 179 F.3d 990, 995 (6th Cir. 1999); Hassine v. Zimmerman, 160 F.3d 941, 953 (3d Cir. 1998); Hogue v. Johnson, 131 F.3d 466, 498-500 (5th Cir. 1997); Sherman v. Smith, 89 F.3d 1134, 1141 (4th Cir. 1996); Castro v. Oklahoma, 71 F.3d 1502, 1515-16 (10th Cir. 1995); Tyson v. Trigg, 50 F.3d 436, 446-47 (7th Cir. 1995); Horsley v. Alabama, 45 F.3d 1486, 1492 (11th Cir. 1995). Two circuits have dodged the issue. See Tapia v. Roe, 189 F.3d 1052, 1056-57 (9th Cir. 1999); Lyons v. Johnson, 99 F.3d 499, 503 (2d Cir. 1996).

75. Several commentators are vehemently opposed to this curtailment of habeas. See, e.g., Friedman, Failed Enterprise, supra note 9, at 495 (criticizing Brecht for making it more difficult for petitioners to obtain relief); Larry W. Yackle, The Habeas Hagioscope, 66 S. CAL. L. REV. 2331, 2410 (1993) ("The diluted standard for constitutional trial errors is hostile to the very nature of the federal courts' jurisdiction in habeas corpus.").

76. See supra note 52 . 
that inform the public policy decision to narrow the writ. These considerations favor the creation of a narrower writ that rests upon a considered theory of habeas and that yields what society deems to be fair and consistent outcomes. Congress has several options when deciding which federal constitutional claims may be relitigated on habeas. Four basic approaches have been advanced in judicial opinions and in the academic literature-from using the writ solely as a backstop for failures in state review to confining prisoners to the law as it existed at some time in the past. This part identifies these approaches and concludes that Congress should delineate which federal constitutional claims may be relitigated on habeas and should allow those claims to be raised based on the current law, regardless of their prior litigation in state court. This part then reviews the five primary ways in which Congress might select the constitutional claims subject to relitigation on habeas and finds that claims should be chosen based on how fundamental they are to the fairness of the criminal justice process, keeping in mind the function of the writ of habeas corpus as a final layer of appeal after state court review.

\section{A. The Broader Questions}

When Congress considers amending the statute that defines the substantive scope of the federal writ of habeas corpus as it applies to state prisoners, it is undertaking a largely normative task. Over the past 130 years, the federal courts have been limited to asking, "What can the scope be in light of the statutory text?"77 Congress, however, has a much wider berth and may inquire, "What should the scope be?",78

As a result, Congress may delve into more fundamental questions, such as whether federal habeas review should be provided at all. The answer to that question is undoubtedly yes. To be sure, federal habeas review is not without cost. Allowing a lower federal court to review the judgments of state supreme courts is perceived by many to be an affront to state sovereignty. ${ }^{79}$ The Supreme Court has also

77. In light of Congress's refusal to amend the statutory language of the writ since 1867, it is not surprising that the battle over the substantive scope of the writ has taken place in the courts. See Baird, supra note 5, at 299 ("The scope of the writ of habeas corpus has been defined more by judicial decision than by statute.").

78. Of course, Congress's normative inquiry is still bounded by the Constitution's Suspension of the Writ Clause. See U.S. ConsT. art. I, § 9. The Constitution's limits are discussed infra at Part V.

79. Section 2254 's requirement that the habeas petition be "in custody," 28 U.S.C. $\S 2254$ 
repeatedly observed that federal habeas review undermines the finality of state convictions ${ }^{80}$ and takes up valuable federal judicial resources. ${ }^{81}$

Federal habeas review is nevertheless appropriate. Federal court review of state convictions is likely to ferret out federal constitutional violations that the state courts have missed, allowing habeas to serve as an important bulwark in protecting those rights deemed vital enough to be cognizable on habeas. The existence of federal habeas review of at least some constitutional claims also provides a forum for the development of federal constitutional law that would otherwise be confined to the United States Supreme Court's review of convictions on direct appeal. ${ }^{82}$ Such review may, as a final matter, be constitutionally required, as the constitutional prohibition against suspension of the writ would, at a minimum, appear to imply the existence of the writ. ${ }^{83}$

Congress may also ask whether the writ, once established, should reach all federal constitutional claims. There are several reasons why Congress might want to have the federal courts relitigate all federal constitutional violations. By placing no violation beyond the scrutiny of the federal courts, the federal courts would surely be more likely to uncover all possible constitutional violations and to deter state actors

(Supp. III 1997), links habeas relief to the state prisoner's challenge to her conviction or sentence because, in the postconviction context, the prisoner is almost always "in custody" pursuant to the conviction or sentence. Thus, federal habeas in this context is actually a tool for attacking final state judgments of conviction.

80. See Brecht v. Abrahamson, 507 U.S. 619, 635 (1993) (emphasizing the "State's interest in the finality of convictions that have survived direct review within the state court system"); Herrera v. Collins, 506 U.S. 390, 426 (1993) (O'Connor, J., concurring) (“At some point in time, the State's interest in finality must outweigh the prisoner's interest in yet another round of litigation."); Teague v. Lane, 489 U.S. 288, 309 (1989) (plurality) (recognizing that finality is "essential to the operation of our criminal justice system"); see also Friedman, Failed Enterprise, supra note 9, at 528 ("Probably at the top of the Supreme Court's own list of priorities is finality.").

81. In 1995, for example, federal and state prison inmates filed over 14,000 habeas corpus petitions. See SCALIA, supra note 52, at 3.

82. See Jordan Steiker, Incorporating the Suspension Clause: Is There a Constitutional Right to Federal Habeas Corpus for State Prisoners?, 92 MicH. L. REV. 862, 866 (1994) [hereinafter Steiker, Incorporating] ("Were the lower courts not enlisted in the effort [of interpreting federal constitutional law], federal habeas would surely cease to exist as an effective remedy for state prisoners."); see also Robert M. Cover \& T. Alexander Aleinikoff, Dialectical Federalism: Habeas Corpus \& the Court, 86 YALE L.J. 1035, 1036 (1977) (arguing that the Warren Court's indulgence of large-scale relitigation of constitutional claims in federal court helped to create a dialogue between federal and state courts on federal constitutional law).

83. See U.S. Const. art. I, § 9, cl. 2; see also infra Part V (discussing the Suspension of the Writ Clause in greater detail). 
(including state courts) from committing violations in the first place. ${ }^{84}$ Such broad review might have costs over and above those attendant to narrower review, however, and might end up harming the state prisoners it is designed to help. Not foreclosing any constitutional claim (or any frivolous claim recast as a constitutional violation) from review may provoke a greater volume of meritless claims, and, as Ju stice Jackson observed, "[i]t must prejudice the occasional meritorious application to be buried in a flood of worthless ones. ${ }^{, 85}$ This Article takes no position on the wisdom of narrowing the substantive scope of habeas, which is a debate that predates Stone v. Powell ${ }^{86}$ and the modern debate over the contours of the writ's substantive scope. Instead, the Article assumes that the policy judgment to narrow the writ has already been made and concentrates on the best way to proceed with that policy.

The next question to ask is whether there is anything wrong with taking an ad hoc approach to narrowing the substantive scope of habeas. After all, as discussed more fully below, the Supreme Court has arguably failed to hew a straight course when excluding claims from habeas review, particularly in its decisions to exclude Fourth Amendment claims but to retain Miranda claims. ${ }^{87}$

There are good reasons not to follow the Court's lead in this regard. As an initial matter, the Court's handiwork has not met with widespread approval, even among those who believe it is appropriate to narrow the writ's scope. ${ }^{88}$ More importantly, however, having a coherent theory underlie any revisions to habeas respects state sovereignty, an issue that goes to the core of federal habeas review. ${ }^{89}$ As the Court has noted time and again, habeas review by federal courts is a substantial intrusion on state sovereignty, one that requires justification..$^{90}$ If Congress lacks a cogent theory to guide its reformation of the writ's scope and permits state convictions to be overturned on

84. This argument underlies the "deterrence theory" of habeas discussed more fully infra at Part II.B.2.

85. Brown v. Allen, 344 U.S. 443, 537 (1953) (Jackson, J., concurring in the result).

86. 428 U.S. 465 (1976).

87. See infra Part II.B.3. By contrast, Congress, in the plain language of $\S 2254($ a), has arguably followed a consistent theory-namely, that review of all federal constitutional claims is warranted. See 28 U.S.C. § 2254(a) (Supp. III 1997).

88. See infra Part II.B.3.

89. State sovereignty is implicated most directly because the grant of habeas relief by a federal court overturns a state conviction or sentence. See supra notes 79-80 and accompanying text.

90. See Brecht, 507 U.S. at 528-29. 
some subset of federal constitutional grounds that is selected on an ad hoc basis, the federal intrusion on the finality of state judgmentsand, consequently, on state sovereignty itself-would seem to be less justified than if that subset were selected after considered judgments by a Congress working from a cogent theory of habeas. Lastly, having a consistent theory makes sense as a practical matter. If Congress chooses, as it often does in other contexts, to refine the substantive scope of the writ one step at a time, a consistent theory would provide a ready blueprint for future legislative action and would consequently give Congress greater freedom to act in a piecemeal fashion. The Article now turns to the task of evaluating the possible theories that might support a narrower writ.

\section{B. Approaches to Narrowing Habeas}

There are several possible ways to distinguish constitutional claims that may be relitigated on habeas from those that may not. At one extreme, Congress could close the habeas courts to all constitutional claims, except those that the petitioner was not given a "full and fair opportunity" to present in state court. ${ }^{91}$ A second, less polar option is to permit the federal courts to hear any constitutional claim but to have the courts' ability to hear a claim turn on whether the claim is accompanied by a colorable showing of actual innocence. ${ }^{92} \mathrm{~A}$ third option is to allow a petitioner to raise any constitutional claim, but only under the relevant law that existed at some time in the past (for instance, when the petitioner's conviction became final). ${ }^{93}$ Finally, Congress could simply decide ahead of time which constitutional claims a petitioner may relitigate on habeas. Those constitutional claims would then always be cognizable on habeas (regardless of the petitioner's innocence, what happened in state court, and what the law was at some prior point in time). Each method of restricting habeas, along with its benefits and drawbacks, will be discussed in turn.

91. Paul M. Bator, Finality in Criminal Law and Federal Habeas Corpus for State Prisoners, 76 HARV. L. ReV. 441, 456 (1963). Along these same lines, Senator Jon Kyl introduced a bill during the last session of Congress that would have foreclosed federal habeas review "unless the remedies in the courts of the State are inadequate or ineffective to test the legality of the detention of the person." Crime Prevention Act of 1997, S. 488, 105th Cong., § 601(a).

92. See Henry J. Friendly, Is Innocence Irrelevant? Collateral Attack on Criminal Judgments, 38 U. CHI. L. REV. 142, 142 (1970).

93. See Teague v. Lane, 489 U.S. 288, 306-09 (1989) (plurality). 
1. Full and Fair Opportunity Approach. This approach to federal habeas, first espoused by Professor Paul Bator in his seminal 1963 article, starts from the premise that the writ of habeas corpus itself is an historical exception to the general rule of res judicata, which would normally bar federal courts from reviewing judgments of the state courts. ${ }^{94}$

This approach rests heavily on a particular reading of the history of the writ in America. At common law, Bator recounts, the writ of habeas corpus assured little more than a conviction in a court of competent jurisdiction. ${ }^{95}$ The Judiciary Act of 1789 established the writ for federal prisoners and, by failing to define any broader scope, seemingly incorporated the common law's narrow writ. ${ }^{96}$ Although the Reconstruction Congress amended the statutory language to reach "all cases where any person may be restrained ... in violation of the Constitution, or of any treaty or law of the United States,"97 the Supreme Court did not expand the writ much beyond jurisdictional inquiries until the early twentieth century. ${ }^{98}$ At that point, the Court began to entertain constitutional challenges to convictions if a state's corrective

94. Admittedly, $\S 2254$ purports to test the legality of a state prisoner's "custody." 28 U.S.C. § 2254(a) (Supp. III 1997) ("The [federal courts] ... shall entertain an application for a writ of habeas corpus in behalf of a person in custody pursuant to the judgment of a State court only on the ground that he is in custody in violation of the Constitution or laws or treaties of the United States." (emphasis added)). In most cases, testing a prisoner's "custody" involves a challenge to his underlying conviction. But because habeas focuses on custody, habeas is also available to challenge the constitutionality of prison disciplinary sanctions if they affect the length or duration of a prisoner's sentence. See Heck v. Humphrey, 512 U.S. 477, 487 (1994) (recognizing that habeas is the proper remedy when "a judgment in favor of the plaintiff would necessarily imply the invalidity of his conviction or sentence"); Edwards v. Balisok, 520 U.S. 641, 645-47 (1997) (same).

95. See Bator, supra note 91, at 466 (noting that, soon after 1789, "the Supreme Court accept[ed] the black-letter principle of the common law that the writ was simply not available at all to one convicted of a crime by a court of competent jurisdiction"); Peller, supra note 5, at 610-16 (objecting to Bator's explanation for the writ's narrow scope, though not disagreeing with Bator's characterization of the narrow scope of the writ during this period).

96. The Judiciary Act of 1789 provided that the courts of the United States "shall have power to issue writs of ... habeas corpus.” Act of Sept. 24, 1789, ch. 20, § 14, 1 Stat. 73, 81.

97. Habeas Corpus Act of 1867, ch. 28, 14 Stat. 373, 385 (1867).

98. To be sure, there is considerable academic debate about whether the Supreme Court's stingy interpretation of the writ during this period was the product of a narrow view of the writ of habeas corpus or a consequence of the fact that the Constitution at that time had not been broadly interpreted to guarantee any more than the jurisdiction of the convicting court. Compare Bator, supra note 91, at 471-85 (developing the historical argument that the Supreme Court viewed habeas narrowly), with Peller, supra note 5, at 621-30 (claiming that, historically, "[t]he state court's jurisdiction was relevant only to the merits of the due process claim, not the jurisdiction of the habeas court"). 
procedures were inadequate. ${ }^{99}$ It was not until 1953, however, in Brown v. Allen, ${ }^{100}$ that the Supreme Court interpreted section 2254 to permit relitigation of constitutional claims previously raised in state courts. ${ }^{101}$

Bator reasons that because the Supreme Court had not (until the early 1900s) viewed habeas as a writ of error, ${ }^{102}$ the writ was-and, under this view, still should be-generally unavailable for relitigating constitutional claims because such relitigation could upset a final judgment of conviction. Thus, the only time it would be appropriate to revisit a conviction through habeas is when there were some defect with the state court's process of review. As Bator puts it, "if a job can be well done once, it should not be done twice." 103 This would leave the writ open only to state prisoners able to demonstrate that "the processes furnished by the previous [state] tribunal were [not] meaningful and rational." ${ }^{104}$

There are several reasons why Congress may not wish to codify Bator's "full and fair opportunity" approach when retooling the federal writ. Initially, it rests on the general assumption that state judges are as competent as federal judges in litigating federal constitutional claims (thereby negating any need for federal error correction). It is unclear whether this assumption of parity is valid, however. Academics and politicians are sharply divided on this issue. ${ }^{105}$ Basing the

99. See Frank v. Mangum, 237 U.S. 309, 335 (1915) (reasoning that, "if the State, supplying no corrective process, carries into execution a judgment of death or imprisonment based upon a verdict thus produced by mob domination, the State deprives the accused of his life or liberty without due process of law" and arguing that habeas might therefore be appropriate); see also Moore v. Dempsey, 261 U.S. 86, 90-92 (1923) (following the Frank rule and remanding for determination of whether the state corrective process was adequate).

100. 344 U.S. 443 (1953).

101. See id. at 460-65.

102. See Bator, supra note 91, at 471 ("The essential touchstone [of the Court's precedent] continued to be that the writ of habeas corpus was not to be used as a writ of error ....").

103. Id. at 451.

104. Id. at 456. Bator would also permit habeas petitioners to challenge the jurisdiction of the state court, see id. at 460-62, but the rarity of state proceedings lacking jurisdiction renders the "failure of process" exception, $i d$. at 455 , the primary avenue for review under his model.

105. As Professor Chemerinsky astutely observed, "in the academic literature, much of the disagreement over the scope of habeas corpus is based on differing views of the relative competence of federal and state courts." Chemerinsky, supra note 5, at 764; see also Barry Friedman, Habeas and Hubris, 45 VAND. L. REV. 797, 819 (1992) [hereinafter Friedman, Habeas and Hubris] ("Parity, however, is a controversial topic. Academics debate whether parity really exists."); Ann Woolhandler, Demodeling Habeas, 45 STAN. L. REV. 575, 634 (1993) ("Whether state courts are as effective as federal courts in enforcing federal rights remains a central issue."). Compare Bator, supra note 91, at 509 ("There is no intrinsic reason why the fact that a 
writ on such a contested premise may be unwise. On a more practical level, the "full and fair" approach would require federal courts to inquire into the sufficiency and fairness of state court procedures. Many view this type of probing into the procedures of a state court system as more offensive to state courts than simple error correction, ${ }^{106}$ although, in its defense, it is arguably no worse than the routine inquiry courts engage in when determining whether to grant the findings of other courts preclusive effect. ${ }^{107}$ Finally, even those Supreme Court Justices who are sympathetic to this approach nevertheless acknowledge that it still may be appropriate for federal courts to review the merits of some constitutional claims. ${ }^{108}$ Consequently, this approach may narrow the writ too much, beyond what even the advocates of

man is a federal judge should make him more competent, or conscientious, or learned with respect to the applicable federal law than his neighbor in the state courthouse."), and Friendly, supra note 92 , at $165 \&$ n. 26 (rejecting the notion that state judges are less competent than federal judges), with Evan Tsen Lee, The Theories of Federal Habeas Corpus, 72 WASH. U. L. Q. 15, 202 ("In enacting [the 1867 habeas] statute, the 39th Congress essentially made a legislative finding that state courts are less trustworthy in the vindication of civil rights and civil liberties than federal courts."), and Burt Neuborne, The Myth of Parity, 90 HARV. L. REV. 1105, 1120-21 (1977) (arguing that federal judges have greater "technical competence," a superior "psychological set," and better insulation from the majoritarian processes because of their life tenure), and Peller, supra note 5, at 677 ("[I]f state and federal judges were equally sensitive to federal constitutional requirements, there would be little need for federal courts to review state court decisions ....").

Congress also grapples with this issue. During this session, the House passed the Interstate Class Action Jurisdiction Act of 1999, which would move nearly all state court class actions to federal court. See H.R. 1875, 106th Cong. Much of the impetus behind this legislation stems from the belief that state court judges are not competent to handle the complexities of class action litigation. See H.R. REP. No. 106-320, at 9 (1999) (justifying the bill as necessary to counteract " $[\mathrm{t}]$ he lax attitudes of some State courts and those courts' ineffectiveness in managing class action litigation").

106. See Friedman, Failed Enterprise, supra note 9, at 540 ("It is difficult to think of an approach more inherently damaging to the notion of comity than to invite the federal courts into the state proceedings, to ensure the state judges provided a 'full and fair hearing."'); see also Chemerinsky, supra note 5, at 777-78 \& n.157 (arguing that a "full and fair" approach may produce greater friction between state and federal courts); Cover \& Aleinikoff, supra note 82, at 1043 (regarding as problematic the "potentially insulting inquiries into the reasons for the failure of the [state] trial judge to raise and correct errors not called to his attention by the defense").

107. See, e.g., Parklane Hosiery Co. v. Shore, 439 U.S. 322, 332-33 (1979) ("Since the petitioners received a 'full and fair' opportunity to litigate their claims in the [prior] action, the contemporary law of collateral estoppel leads inescapably to the conclusion that the petitioners are collaterally estopped from relitigating [the legal question at issue].”).

108. See, e.g., Withrow v. Williams, 507 U.S. 680, 720 (1993) (Scalia, J., dissenting) ("Prior opportunity to litigate an issue should be an important equitable consideration in any habeas case, and should ordinarily preclude the court from reaching the merits of a claim, unless it goes to the fairness of the trial process or to the accuracy of the ultimate result." (second emphasis added)). 
the most sweeping habeas reform contemplate. Thus, although this approach rests on a coherent theory, it has practical difficulties, and it may go too far in curtailing the writ. ${ }^{109}$

2. The "Colorable Innocence" Approach. Articulated most ardently by Judge Henry Friendly, this approach would permit a state prisoner to raise any federal constitutional claim on federal habeas as long as the prisoner can show "a fair probability that, in light of all the evidence ... the trier of facts would have entertained a reasonable doubt of his guilt." that substantiation of guilt or innocence is "vital" in "determining whether collateral relief should be available to a convicted defendant." 111

Despite this laudable and coherent rationale, this approach has several drawbacks. First, it does not recognize innocence as an independent basis for release on habeas. Instead, a colorable showing of innocence acts solely as a gateway into federal court for petitioners

109. This theory also rests on a historical pedigree that is refutable. See Peller, supra note 5 (defending a broader interpretation of federal habeas review against the Burger Court's restrictive reading). Academics have generally conceded that the history of the writ does not clearly reflect—or, more relevant to current academic discourse, support-any single theory of habeas. See, e.g., Hoffmann \& Stuntz, supra note 50, at 74 ("[T] he habeas statute simply does not speak to any of the key issues in habeas law ... [and] does not define habeas's substantive scope."); $i d$. at 79 (noting that the history of the writ of habeas is unhelpful); James S. Liebman, Apocalypse Next Time?: The Anachronistic Attack on Habeas Corpus/Direct Review Parity, 92 Colum. L. REV. 1997, 2033 (1992) (observing that the historical debate between Professors Bator and Peller "ends in an uninformative draw, as neither thesis can explain important [Supreme Court] decisions that both theses must explain in order to convince"); McCord, supra note 5, at 738 ("[D]epending on which piece of history one grasps, the writ takes on an entirely different cha racter."); Woolhandler, supra note 105, at 643 ("[H]istory does not necessarily dictate a particular result in the current debate as to the proper scope of habeas ....").

110. Friendly, supra note 92 , at 160 . The evidence to be considered in this inquiry includes evidence "alleged to have been illegally admitted (but with due regard to any unreliability of it) and evidence tenably claimed to have been wrongly excluded or to have become available only after the trial." Id.

Judge Friendly did not advocate a pure "colorable innocence" approach, however. He would have waived the requisite showing for: (i) petitioners whose "[habeas] attack concerns the very basis of the criminal process" (e.g., claims of deprivation of counsel, racial discrimination in jury selection, excess publicity, and improper influences on a court officer); (ii) petitioners who can show that there has been no prior full and fair opportunity to raise a constitutional claim, which would encompass cases where "collateral attack is the only avenue for the defendant to vindicate his rights"; (iii) cases "where the state has failed to provide proper procedure for making a defense at trial and on appeal"; and (iv) petitioners whose claims involve "[n]ew constitutional developments relating to criminal procedure." Id. at 152-53.

111. Id. at 142 (quoting Kaufman v. United States, 394 U.S. 217, 235-36 (1969) (Black, J., dissenting)). 
wishing to raise federal constitutional claims that may or may not be related to the accuracy of the underlying guilty verdict or to their actual guilt or innocence. In this respect, this approach would adopt for all habeas review a "miscarriage of justice" exception similar to the one that the Supreme Court currently uses as a gateway to overcome procedural defaults and successive habeas petitions. ${ }^{112}$ Under this approach, it is possible - and, indeed, foreseeable - that a petitioner's constitutional claim might be rejected, even though she made the requisite "colorable showing of innocence." In this situation, a prisoner who had effectively established a reasonable likelihood that she were innocent would be denied relief and remain in prison notwithstanding this showing. ${ }^{113}$ By making innocence the primary focus of access, but making the merit of constitutional claims the focus of relief, this approach is somewhat at odds with itself, and it might lead to results that appear unfair.

To be sure, Congress could remedy this internal inconsistency by enacting a writ that views innocence both as a gateway to review of all constitutional claims and as an independent basis for relief. This approach has a common-sense appeal to it: habeas would be reserved for the innocent, not for those hoping to "get off on a technicality." Even a writ structured along these lines would not solve all of the problems with an innocence-based focus, however. First, such a writ, as one would expect, places almost exclusive weight on a petitioner's innocence. While protection of the innocent is clearly a value enshrined in the Constitution, it is not the only value. Several constitutional guarantees, including many of those considered to be so important that breaches thereof are deemed "structural error," protect procedural regularity and have little or nothing to do with the accuracy of the guilty verdict. ${ }^{114}$ Because these protections would likely be unavailable on habeas under this approach, some of the "legal techni-

112. See Coleman v. Thompson, 501 U.S. 722,748 (1991) (discussing the "miscarriage of justice" exception to the procedural default doctrine, which requires a showing that a constitutional violation "probably resulted in the conviction of one who is actually innocent"); McCleskey v. Zant, 499 U.S. 467, 494-96 (1991) (recognizing the same exception to the "abuse" of the writ and "successive" writ doctrines); see also supra text accompanying notes 29-32, 45.

113. See Steiker, Restructuring, supra note 50, at 327 (stating that the "colorable showing of innocence" approach turns habeas on its head).

114. See, e.g., Vasquez v. Hillery, 474 U.S. 254, 264 (1986) (holding that racial discrimination in grand jury selection warrants automatic reversal even if the trial itself is free from error and the verdict presumably accurate); see also Kimmelman v. Morrison, 477 U.S. 365, 380 (1986) ("The constitutional rights of criminal defendants are granted to the innocent and the guilty alike."). 
calities" that this approach would effectively nullify on habeas are some of the most essential process-oriented protections of the Constitution. Second, this approach would require an individualized, caseby-case examination of each habeas petitioner's innocence, turning the writ into little more than a vehicle for assessing error in a verdict. ${ }^{115}$ This would constitute a great shift in the function of the federal habeas courts, which until now have devoted more effort to evaluating the merits of legal claims raised by habeas petitioners than to sifting through the raw facts and reassessing guilt. As these criticisms highlight, the theoretical and practical impact of the "colorable innocence" approach makes it less than ideal for undergirding a new, cohesive statutory writ.

3. The Temporal Approach. A third option, already adopted by the Supreme Court, is to limit habeas petitioners to raising constitutional claims available to them at some time in the past-usually, when their convictions became "final" at the conclusion of direct review. In Teague v. Lane, ${ }^{116}$ the Court announced the current law that governs the circumstances under which prisoners litigating state or federal habeas petitions would be able to avail themselves of favorable precedent handed down after their direct appeals concluded. Prior to Teague, the Court followed an individualized approach to the question of retroactivity, evaluating for each new precedent "the purpose to be served by the new standards," "the extent of the reliance by law enforcement authorities on the old standards," and "the effect on the administration of justice of a retroactive application of the new standards." 117 Teague moved away from this individualized approach and adopted a categorical rule regarding the retroactivity of decisions handed down after a prisoner's direct appeal is over and collateral review has begun. ${ }^{118}$

115. See Cover \& Aleinikoff, supra note 82, at 1089 ("A case-by-case focus would degenerate into a weaker variant of the constitutional harmless error rule.").

116. 489 U.S. 288 (1989).

117. Stovall v. Denno, 388 U.S. 293, 297 (1967). This tripartite test is commonly referred to as the Linkletter standard, after Linkletter v. Walker, 381 U.S. 618 (1965), the case in which it was first announced.

118. Just two years earlier, the Court had adopted a categorical rule permitting prisoners litigating their direct appeals to rely upon newly announced precedent. See Griffith v. Kentucky, 479 U.S. 314, 328 (1987) (stressing that "a new rule for the conduct of criminal prosecutions is to be applied retroactively to all cases, state or federal, pending on direct review or not yet final"). 
Under Teague's regime, subsequent decisions that announce "new rules"-as opposed to decisions that merely clarify prior precedent-should not generally "be applied retroactively to cases on collateral review." ${ }^{, 19}$ As a result, state prisoners filing state or federal habeas petitions cannot usually rely upon any "new rules" of constitutional criminal procedure in seeking relief.

Teague's anti-retroactivity rule is a broad one. A rule is considered "new" any time it "breaks new ground [or] imposes a new obligation on the States or Federal Government" or if it was not "dictated" or "compelled" by existing precedent at the time the defendant's conviction became final. ${ }^{120}$ Put another way, a rule is "old"- that is, available on habeas — only if "it can be said that a state court, at the time the conviction or sentence became final, would have acted objectively unreasonably by not extending the relief later sought in federal court." ${ }^{121}$ Given these definitions, there are few changes in precedent that do not constitute "new rules" barred by Teague.

Teague does contain two exceptions, however. ${ }^{122}$ A "new rule" may be applied retroactively on habeas if it "forbid[s] criminal punishment of certain primary conduct [or] prohibit[s] a certain category of punishment for a class of defendants because of their status or offense," the fundamental fairness and accuracy of the criminal proceeding." In the decade since Teague was announced, the Court has only once found a rule fitting within the first exception; ${ }^{125}$ no "new rule" has yet

119. Teague, 489 U.S. at 305 .

120. See Saffle v. Parks, 494 U.S. 484, 488 (1989) ("[O]ur task is to determine whether a state court considering [a habeas petitioner's] claim at the time his conviction became final would have felt compelled by existing precedent to conclude that the rule [that the petitioner] seeks was required by the Constitution."); accord Lambrix v. Singletary, 520 U.S. 518, 526 (1997) (quoting the above language from Saffle); Gray v. Netherland, 518 U.S. 152, 166 (1997) (same); Teague, 489 U.S. at 305 (holding that "a case announces a new rule if the result was not dictated by precedent existing at the time the defendant's conviction became final").

121. O'Dell v. Netherland, 521 U.S. 151, 156 (1997).

122. As the Court notes in Teague, these exceptions are derived from Justice Harlan's opinions in Mackey v. United States, 401 U.S. 667 (1971) (Harlan, J., concurring in part and dissenting in part), and Desist v. United States, 394 U.S. 244 (1969) (Harlan, J., dissenting). See Teague, 489 U.S. at 304.

123. Penry v. Lynaugh, 492 U.S. 302, 330 (1989).

124. Graham v. Collins, 506 U.S. 461, 478 (1993) (quoting Saffle, 494 U.S. at 495).

125. See Penry, 492 U.S. at 330 (holding that a "new rule" barring the execution of mentally retarded persons fits within Teague's first exception). 


\section{satisfied the second exception. ${ }^{126}$ Teague-or a harsher variant thereof-was codified by Congress in the Antiterrorism and Effective Death Penalty Act of 1996 ("AEDPA"). ${ }^{127}$}

126. See O'Dell, 521 U.S. at 167 (holding that the rule entitling a death-eligible defendant to a jury instruction telling the jury that he is ineligible for parole would be a "new rule" that does not meet Teague's second exception); Gray v. Netherland, 518 U.S. 152, 170 (1997) (holding that the rule requiring the state to give notice to a defendant of the evidence it plans to present at a sentencing hearing would be a "new rule" that does not satisfy Teague's second exception); Lambrix v. Singletary, 520 U.S. 518, 539 (1997) (holding that the rule governing relief available when judge and jury weigh invalid aggravating factors when handing down a death sentence would be "new," but not a "watershed," rule); Goeke v. Branch, 514 U.S. 115, 120 (1995) (holding that the rule granting substantive due process protection against the required dismissal of a fugitive's appeal would be a "new" rule that is not "so central" as to fit within Teague's second exception); Caspari v. Bohlen, 510 U.S. 383, 396 (1994) (holding that the double jeopardy rule preventing a state from twice subjecting a defendant to a noncapital sentencing hearing would be a "new," but not a "watershed," rule); Gilmore v. Taylor, 508 U.S. 333, 345 (1993) (holding that the rule requiring an express jury instruction that precluded the jury from returning a murder conviction if it concluded that the defendant possessed a mitigating mental state would be "new," but not a "watershed," rule); Graham, 506 U.S. at 478 (holding that the Fourteenth Amendment due process right not to have a sentencing jury follow the state's threequestion procedure would be a "new rule" that is not a "watershed rule"); Sawyer v. Smith, 497 U.S. 227, 241-43 (1990) (holding that the Eighth Amendment rule prohibiting the imposition of a death sentence by a sentencer with a false sense of responsibility would be a "new rule," but not a "watershed" rule); Butler v. McKellar, 494 U.S. 407, 416 (1990) (holding that the rule that the Fifth Amendment bars police-initiated interrogation following a suspect's request for counsel in a separate investigation is a "new rule," but not a "watershed" rule); Saffle v. Parks, 494 U.S. 484, 495 (1989) (holding that the Eighth Amendment right to allow a jury to base its sentencing decision on sympathy is not a "watershed rule"); Teague, 489 U.S. at 314-15 (plurality) (holding that the Sixth Amendment right to a representative petit jury would be a "new rule" not falling within the ambit of the second exception); see also Yeager, supra note 50, at 700 ("Of the seven claims to which the Court ... applied Teague's second exception to nonretroactivity [in 1994], none ... satisfied it."); Joanne T. Hannaway, Note, O’Dell v. Netherland: A Bedrock Principle of Fundamental Fairness?, 29 LOY. U. CHI. L.J. 943, 982 (1998) (emphasizing that, "since Teague, no Supreme Court case has ever found a rule to qualify under Teague's second exception"). A few lower federal courts have, however, identified some constitutional rights fitting within Teague's exception. See Hannaway, supra, at 963 n.145 (listing cases in which lower courts have found a new rule to satisfy Teague's second exception).

127. 28 U.S.C. $\$ 2254$ (d)(1) (Supp. III 1997) provides :

An application for a writ of habeas corpus on behalf of a person in custody pursuant to the judgment of a State court shall not be granted with respect to any claim that was adjudicated on the merits in State court proceedings unless the adjudication of the claim-

(1) resulted in a decision that was contrary to, or involved an unreasonable application of, clearly established Federal law, as determined by the Supreme Court of the United States.

Both judges and professors are unsure about the effect of this provision. See Tung Yin, A Better Mousetrap: Procedural Default as a Retroactivity Alternative to Teague v. Lane and the Antiterrorism and Effective Death Penalty Act of 1996, 25 AM. J. CRIM. L. 203, 221 \& n.116 (1998) (collecting citations illustrating the confusion of whether the provision "codifies" or "displaces" Teague). 
The adoption of a Teague-type temporal limitation as a model for reshaping habeas has several disadvantages. To begin with, the theory underlying this sort of temporal approach implicates the same nettlesome "parity" debate as the "full and fair opportunity" approach. ${ }^{128}$ By limiting habeas petitioners to the federal law that they could have cited on direct appeal, Congress might be highlighting the notion that habeas exists solely to police the state courts' compliance with federal law, which implies they need such supervision. ${ }^{129}$ Indeed, the Supreme Court noted the "deterrence function" of habeas in Teague itself. ${ }^{130}$

While deterrence itself is an internally consistent rationale, it may not be well suited as a theoretical foundation for habeas because it implies the incompetence of state actors and because any deterrent effect from overturning convictions on habeas may come too late or too sporadically to be effective. ${ }^{131}$ The latter rationale-that reversals on habeas months and years after wrongful behavior are often ineffective deterrents-was cited by the Supreme Court in Stone v. Powell, ${ }^{132}$ when it held that Fourth Amendment exclusionary rule claims should usually not be heard on habeas. ${ }^{133}$ Furthermore, a temporal limitation on claims that binds habeas courts to the law as it existed on a past date prevents those courts from assisting in the evolution of the law of federal constitutional criminal procedure, which leaves a

128. See supra Part II.A.1.

129. See Yin, supra note 127, at 207 ("Teague is premised largely on grounds of finality and deterrence.").

130. Teague, 489 U.S. at 306 (quoting Desist v. United States, 394 U.S. 244, 262-63 (1969) (Harlan, J., dissenting)):

" $[\mathrm{T}]$ he threat of habeas serves as a necessary additional incentive for trial and appellate courts throughout the land to conduct their proceedings in a manner consistent with established constitutional standards. In order to perform this deterrence function, ... the habeas court need only apply the constitutional standards that prevailed at the time the original proceedings took place."

131. See Lee, supra note 105, at 175-76 (arguing that "the deterrence argument [in Teague] was little more than a makeweight" and was later rejected in Brecht v. Abrahamson, 507 U.S. 619 (1993)); see also SCALIA, supra note 52, at 6 (observing that only 1.2\% of the 11,841 habeas petitions filed in federal district court by state prisoners were granted). Of course, these criticisms are themselves not above reproach. The very purpose of incorporation was to interpose the Constitution between state actors and criminal defendants. Moreover, the low grant rate for habeas may simply reflect the fact that the deterrent function of federal habeas is, in fact, succeeding.

132. 428 U.S. 465 (1976).

133. See id. at 493 (1976) (reasoning that "the additional contribution, if any, of the consideration of search-and-seizure claims of state prisoners on collateral review is small in relation to the costs"). 
greater part of that task to the Supreme Court. ${ }^{134}$ Finally, a temporal rule may yield unfair results. Whether a particular prisoner may avail himself of a new constitutional rule that may warrant his relief could ultimately turn on whether the Supreme Court denied certiorari from his direct appeal on the third of November, instead of on the third of October. As one might expect, Teague has been roundly criticized on all of these grounds. ${ }^{135}$ For all these reasons, a temporal limitation approach would not appear well suited to serve as a basis for reducing the substantive scope of habeas.

4. The Claim-Based Approach. The first three approaches would make a petitioner's entry to a habeas court contingent upon some factor other than the nature of the federal constitutional objection she wishes to raise-whether the state court procedures were adequate, whether she is innocent, or whether the particular claim is "new" or an outgrowth of established precedent. Alternatively, Congress could simply decide which types of constitutional claims are sufficiently important to warrant relitigation on habeas and which are not. Those that are could be raised on habeas regardless of the petitioner's actual innocence or the vintage of her claim. Those claims that are not could not be relitigated, although a petitioner would be free to establish that, due to inadequacies in state procedure, she would not otherwise be able to litigate the claim at all unless she were able to raise it before the habeas court. As discussed more fully below, this is hardly a novel

134. See Friedman, Habeas and Hubris, supra note 105, at 799-800 ("In Teague v. Lane and its progeny, the Supreme Court silenced the habeas courts."); see also Cover \& Aleinikoff, supra note 82, at 1036 (arguing that the Warren Court's indulgence of large-scale relitigation of constitutional claims in federal court helped to create a dialogue between federal and state courts on federal constitutional law); Steiker, supra note 82, at 866 ("Were the lower courts not enlisted in the effort [of interpreting federal constitutional law], federal habeas would surely cease to exist as an effective remedy for state prisoners."); id. at 922 (“[T]he Court's expansive conception of 'new' law has threatened to undermine lower federal courts' ability to apply established principles to novel fact patterns."). Of course, the Supreme Court would still not be entirely on its own in espousing new federal constitutional law relating to prisoners, as state and federal courts would continue to be able to expound upon the Constitution at trial and on direct appeal. A temporal limitation on federal habeas (and under 28 U.S.C. $\S 2255$ for federal prisoners) would, however, surely lessen the ability of these lower courts to formulate and develop federal constitutional law.

135. See Friedman, Failed Enterprise, supra note 9, at 519 ("Teague is a disaster of judicial administration and doctrinal development.”). See generally Yin, supra note 127, at $206 \mathrm{n} .11$ (collecting articles criticizing Teague "as being fundamentally unfair, internally inconsistent and unreasonably harsh"). 
approach-the Supreme Court (as well as individual Justices) has long toyed with restructuring habeas along these lines. ${ }^{136}$

Because there are several ways to pick and choose among constitutional claims, it is impossible to evaluate whether the claim-based approach in general reflects a principled theory or yields fair results. All claim-based approaches, however, require Congress to place constitutional rights in a hierarchy. Some rights are deemed important enough to warrant relitigation on habeas, while others are not. Many commentators object to this sort of "ranking" of constitutional rights. In their view, if a constitutional right is deemed fundamental enough to be incorporated against the states and made applicable in state trials, neither judges nor legislators are in any position to bar such claims from habeas. ${ }^{137}$

Contrary to these objections, however, it may be perfectly acceptable for Congress to choose which of the federal constitutional claims should be cognizable for state prisoners proceeding under the statutory writ. At the outset, it is important to recognize that the area of constitutional criminal procedure has expanded in the past sixty years. The incorporation and enumeration of federal constitutional rights has in large part converted the federal Constitution into a national code of criminal procedure. ${ }^{138}$ Now there is hardly a trial objec-

136. See infra Part II.B.3.

137. See Friedman, Two Habeas, supra note 1, at 320 ("This ranking of constitutional rights finds no basis in the habeas statute or the Constitution itself."); see also Cover \& Aleinikoff, supra note 82, at 1087 (criticizing the Court's decision in Stone because it established "a hierarchy of constitutional rights for purposes both of enforcement and of substantive articulation"); Peller, supra note 5, at 599-602 (criticizing Stone and its progeny for failing to erect a meaningful way to "identify the [constitutional] claims for which review will be unavailable").

138. See Desist v. United States, 394 U.S. 244, 266 (1969) (Harlan, J., dissenting) (calling the 1960s "a decade that has witnessed revolutionary changes in the most fundamental premises of hitherto accepted constitutional law"); Cover \& Aleinikoff, supra note 82, at 1036 (noting how, in the 1960s, "[t]he Court fearlessly or foolishly brought the celebrated ideals of the federal Constitution to bear on the day-to-day realities of urban administration of criminal justice"); Friedman, Habeas and Hubris, supra note 105, at 798 ("Admittedly, the decades between 1950 and 1980 witnessed sea changes in the interpretations of [the] rights [guaranteed by the Bill of Rights and the due process clause]."); Friedman, Two Habeas, supra note 1, at 275 (observing that Brown v. Allen was decided "at the beginning of the Due Process revolution" when the Court was "broadening and spelling out the scope of substantive federal rights accorded state prisoners"); Hoffmann \& Stuntz, supra note 50, at 67 ("Federal criminal procedure law has become in effect a detailed, national Code of Criminal Procedure that almost totally supersedes state law."); Steiker, Restructuring, supra note 50, at 315 ("When the Warren Court incorporated many of the provisions in the Bill of Rights and applied them against the states, the Court significantly transformed state trials."); Woolhandler, supra note 105 , at 630 (observing that "the Constitution gradually replaced the common law as the authority for policing ad hoc deprivations of liberty and property"). 
tion that cannot be construed to have some constitutional dimension. ${ }^{139}$

Given this expansion, it is not surprising that the Supreme Court has on occasion found it necessary (and advisable) to grant preferential treatment to some constitutional rights in various contexts. ${ }^{140}$ At the most basic level, the Court has chosen to incorporate most-but, importantly, not all—of the provisions of the Bill of Rights against the states. ${ }^{141}$ This clearly involves the ranking of federal constitutional rights. More relevant to the present discussion, the Court has chosen to treat some incorporated rights more preferentially than others in the criminal procedure area. When determining whether a state prisoner is entitled to reversal of his conviction, the Court has held that a violation of most constitutional rights may be ignored if it is not harmful. ${ }^{142}$ The violation of some rights, however, requires automatic reversal regardless of the violation's effect on the trial. ${ }^{143}$ If every one of these "structural errors" defied harmless error analysis, one might be able to argue that the Supreme Court was not creating a hierarchy of rights so much as it was being merely practical. But as not all of the "structural errors" are impervious to harmless error analysis, the Court appears to be preferring some rights over others for constitutionally based policy reasons. ${ }^{144}$ Similarly, the Court has held that cer-

139. See Friedman, Two Habeas, supra note 1, at 322 (observing that "the Constitution now requires elaborate protections for the criminal defendant"); Friendly, supra note 92, at 156 ("Today it is the rare criminal appeal that does not involve a 'constitutional' claim."); LIEBMAN \& HERTZ, supra note 33, at 386 ("The range of claims cognizable in federal habeas corpus proceedings is broad." (citation omitted)).

140. See Yeager, supra note 50, at 675 ("[O]rdering rights is a fact of constitutional litigation.").

141. The only criminal procedure rights contained in the first eight amendments of the Bill of Rights, but not incorporated through the Fourteenth Amendment to the states, are the Fifth Amendment's right to a grant jury indictment, see Hurtado v. California, 110 U.S. 516, 534-35 (1884) (rejecting the argument that the Fifth Amendment's grand jury protection applies to the States), and the Eighth Amendment's guarantee against excessive fines, see Browning-Ferris Indus. v. Kelco Disposal, Inc., 492 U.S. 257, 276 n.22 (1989) (reserving judgment on whether the Excessive Fines Clause has been incorporated).

142. See Arizona v. Fulminante, 499 U.S. 279, 306 (1991) (citation omitted):

Since this Court's landmark decision in Chapman v. California, in which we adopted the general rule that a constitutional error does not automatically require reversal of a conviction, the Court has applied harmless-error analysis to a wide range of errors and has recognized that most constitutional errors can be harmless.

See also supra text accompanying notes 62-69.

143. See supra text accompanying notes 62-67.

144. For example, it seems possible to assess whether grand jury discrimination affected a particular verdict, notwithstanding the Supreme Court's statement in Vasquez v. Hillery, 474 U.S. 254 (1986), that discrimination in grand jury selection is "structural error" in part because 
tain "watershed rules of criminal procedure" may be applied retroactively on federal habeas, even if they are "new rules." ${ }^{145}$ In both contexts, the Court has decided that some incorporated constitutional rights warrant special treatment.

Nor is it logically inconsistent for the Court-or Congress-to prefer some incorporated constitutional rights over others for purposes of habeas. When the Court has held a federal constitutional right applicable to the states through the Fourteenth Amendment, the Court has by definition expressed its view that defendants in state criminal trials should be able to enforce that right at trial. Federal habeas review occurs much later, after the defendant has had an oppor-

of "the difficulty of assessing its effect on any given defendant." $I d$. at 264. Indeed, the Supreme Court's reliance on an alternative policy-based rationale in Vasquez-" $[\mathrm{t}]$ he overriding imperative to eliminate this systemic flaw in the charging process"- may indicate that the Court also perceived the weakness of saying solely that the "structural error" at issue in that case defied harmless error analysis. Id.

As to the other "structural errors," there is more reason to credit the Court's steadfast insistence that the error is structural because it cannot be reviewed for harmlessness. This is particularly so with the right to self-representation because, as the Court noted in McKaskle v. Wiggins, 465 U.S. 168 (1984), exercise of that right often "increases the likelihood of a trial outcome unfavorable to the defendant" and thereby renders any assessment of harmfulness beside the point. Id. at $177 \mathrm{n} .8$ (emphasis added). The remaining "structural errors" defy harmless error analysis only to the extent that a trial with those errors fails to look like a modern criminal trial at all, so that assessing harmlessness with that proceeding as a backdrop is not meaningful. See Sullivan v. Louisiana, 508 U.S. 275, 280 (1993) (holding that errors in a reasonable doubt instruction are per se reversible because, in cases where the instruction is erroneous, "[t]here is no object, so to speak, upon which harmless-error scrutiny can operate"); Waller v. Georgia, 467 U.S. 39, 49 n.9 (1984) (holding that the denial of a public trial is "structural error" in part because "it would be difficult to envisage a case in which [a defendant] would have evidence available of specific injury [necessary to rebut a charge of harmlessness]"” (quoting United States ex rel. Bennett v. Rundle, 419 F.2d 599, 608 (3d Cir. 1969))); cf. Gideon v. Wainwright, 372 U.S. 335, 344-45 (1963) (reversing conviction obtained in violation of the right to counsel, but providing no detailed rationale for its rule of automatic reversal); Tumey v. Ohio, 273 U.S. 510, 533 (1927) (proclaiming that a verdict rendered by a judge who receives money for every guilty verdict is invalid because of the possibility that the defendant "could not get a fair trial or a fair sentence from one who would have so strong a motive to [convict]").

145. In Teague v. Lane, 489 U.S. 288 (1989) (plurality), the Supreme Court held that the nonretroactivity bar does not apply to "watershed rules of criminal procedure," $i d$. at 311 , that are

"best illustrated by recalling the classic grounds for the issuance of a writ of habeas corpus - that the proceeding was dominated by mob violence; that the prosecutor knowingly made use of perjured testimony; or that the conviction was based on a confession extorted from the defendant by brutal methods."

Id. at 313 (quoting Rose v. Lundy, 455 U.S. 509, 544 (1982) (Stevens, J., dissenting) (footnotes omitted)). As one commentator noted, "[t]he two exceptions for when a rule is entitled to retroactive effect even on collateral review are consistent with a rights-selectivist vision, albeit one with a narrow definition of what constitute[] the favored rights." McCord, supra note 5, at 810. As observed above, few constitutional rights meet this standard. See supra notes 123-26. 
tunity to assert the right at trial and on direct appeal (and perhaps in state postconviction review). Thus, the question is no longer, "Should this right be available to state defendants at their trials?" It already has been. Instead, the question is, "Should state defendants be able to relitigate an alleged violation of this federal right in federal court after they have had the opportunity to litigate it before the state courts?" These are different questions, and it seems possible for judges or legislators to answer them differently, but still in a consistent and logical way. ${ }^{146}$

If this objection to the claim-based approach is answered, the next-and most vexing-question is selecting the appropriate criteria to distinguish among constitutional rights. ${ }^{147}$

\section{Selecting Which Constitutional Rights May Be Reheard on Habeas}

When proceeding with a claim-based approach, it is necessary to select a mechanism for deciding which constitutional claims may be raised on federal habeas and which may not. This task has been called "exceedingly difficult," 148 and it has yet to be systematically examined. ${ }^{149}$ Because Congress should only proceed to narrow the writ if the resulting writ reflects a coherent theory, it makes sense to examine the five primary theories of habeas that have been identified in the academic literature and by the courts and to determine whether any of them could provide a theoretical foundation for selecting claims for relitigation on habeas. The five major theories are: (1) the full federal forum model; (2) the deterrence model; (3) the guilt and

146. See Bator, supra note 91, at 508-09 (disagreeing with the notion that constitutional errors are important, while all nonconstitutional errors are unimportant); Friendly, supra note 92, at 156 ("I do challenge ... the assumption that simply because a claim can be characterized as 'constitutional,' it should necessarily constitute a basis for collateral attack when there has been fair opportunity to litigate it at trial and on appeal.”); Hoffmann \& Stuntz, supra note 50, at 92 (reasoning that "[d]ifferent kinds of constitutional claims may require different habeas rules").

147. See Peller, supra note 5, at 599 ("Since the Court has reinterpreted the habeas statute to not require collateral review of all constitutional claims, it is important to identify the claims for which review will be unavailable."); Steiker, Incorporating, supra note 82, at 911 (footnote omitted):

Any theory that posits less than full review of all constitutional issues must offer some basis for establishing a "hierarchy" of constitutional rights. Moreover, such a theory must explain why the hierarchy implicit in the Court's incorporation decisions-applying some, but not all, of the privileges in the Bill of Rights against the statesshould be modified on federal habeas.

148. Yeager, supra note 50, at 683.

149. See McCord, supra note 5, at 758-59 (remarking that "no one has attempted to define exhausitively [sic] which rights fall within these categories"). 
innocence model; (4) the appellate model; and (5) the "fundamental fairness" model. ${ }^{150}$ Their propriety as devices for selecting claims is discussed next.

1. The Full Federal Forum Model. As its name suggests, this theory views federal habeas as "a routine means by which federal claims, both conventional and creative, can be considered in the ordinary course." ${ }^{151}$ Given this premise, few federal statutory or constitutional claims would escape relitigation on habeas. Some proponents of this view would permit state prisoners to relitigate claims in federal court more than once through successive habeas petitions. ${ }^{152}$ Most proponents, however, would allow state prisoners one opportunity to "litigate federal claims in federal court that is roughly equivalent to the opportunity they would have had if they had been allowed to remove the prosecution against them to federal court for original disposition." 153

150. Professor McCord had identified eight "visions of habeas": (1) the de novo litigation vision; (2) the appellate review vision; (3) the rights-selectivist vision; (4) the innocenceselectivist vision; (5) the one-fair-chance vision; (6) the inverse correlation vision; (7) the equitable remedy vision; and (8) the death-is-different vision. See McCord, supra note 5, at 743-86. Professor Lee lists four primary theories of habeas: (1) the process model; (2) the innocence model; (3) the federal forum model; and (4) the deterrence model. See Lee, supra note 105, at 156-75. Professor Chen identifies the same four. See Chen, supra note 57, at 603-08.

Although the names of these theories differ, they are the same theories as those described in the text. What McCord calls the "de novo litigation model" and Lee and Chen call the "federal forum model" is otherwise known as the "full federal forum" approach. What McCord, Lee, and Chen call "the process model" or the "one-fair-chance vision" is the same as Professor Bator's "full and fair opportunity" theory. McCord's "inverse correlation vision" is also known as the "deterrence model," as Chen and Lee call it. Lee's and Chen's "innocence model" corresponds to Judge Friendly's "colorable innocence" model, and McCord's "innocence-selective vision" corresponds to the "guilt and innocence approach" to selecting claims. The only models not accounted for in this Article are the "equitable remedy" vision (which sees the purpose of habeas as doing "justice"), see McCord, supra note 5, at 780, and the "death-is-different" vision (which views death-related claims on habeas as special), see id. at 783-84, but they act more as supplemental rationales than as independent models.

151. Yackle, supra note 75, at 2425-26. Professor Yackle is the primary advocate of this model.

152. Justice Brennan was an adherent of this view, as his majority opinion in Sanders $v$. United States, 373 U.S. 1 (1963), demonstrated. See id. at 8 ("Conventional notions of finality of litigation have no place where life or liberty is at stake and infringement of constitutional rights is alleged.").

153. Yackle, supra note 75 , at 2333. In the last 10 years, the Court has expanded the "abuse of the writ" and successive writ doctrines to make it more difficult for state prisoners to bring multiple habeas petitions. See McCleskey v. Zant, 499 U.S. 467, 493 (1991) (adopting the "cause" and "prejudice" standard to overcome "abuse of the writ" claims); see also J. Thomas Sullivan, The "Burden" of Proof in Federal Habeas Litigation, 26 U. MEM. L. REV. 205, 207 
This theory is ill suited to serve as a criterion for selecting which constitutional claims should be cognizable on federal habeas. To begin with, the premise of this approach - that state prisoners should have a right of access to federal courts for relitigation of their constitutional claims - is at odds with both the historical and modern conceptions of judicial federalism. The lower federal courts owe their very existence to Congress, not to the Constitution. ${ }^{154}$ It is accordingly difficult to establish that there is any sort of historical right to a federal forum. Even if one ignores history and focuses on the federal court system as it exists today, it is clear that the federal courts rarely serve as a forum for relitigating issues-even federal issues-previously adjudicated in state courts. Congress, through the Full Faith and Credit Statute, has made clear its view that the final judgments of state courts should normally not be revisited in federal court, even when they resolve issues of federal law. ${ }^{155}$ Similarly, the Supreme Court has established several abstention doctrines that require the lower federal courts not to intervene in ongoing state proceedings that may involve questions of federal law. ${ }^{156}$ On a more practical level,

(1995) (claiming that in the last decade " $[\mathrm{t}]$ he Court's approach has essentially restricted state prisoners to litigation of constitutional claims in a single federal habeas action, recognizing only quite limited exceptions to this general policy" (footnote omitted)). Congress further restricted the availability of subsequent habeas petitions with the AEDPA. See 28 U.S.C. $§ 2244(b)(1)$ (1994).

154. See U.S. ConsT. art. III, $\S 1$ (vesting the "judicial Power of the United States" in "one supreme Court, and in such inferior Courts as the Congress may from time to time ordain and establish") (emphasis added); Act of Sept. 24, 1789, ch. 20, § 3, 1 Stat. 73, 73-74 (creating the lower federal courts); see also Bator, supra note 91, at 507 ("Surely it is plain that there exists no constitutional right to have the merits of a federal question determined by a federal constitutional court ....").

155. See 28 U.S.C. $§ 1738$ (1994):

Such Acts, records and judicial proceedings [of any State, Territory or Possession of the United States] ... shall have the same full faith and credit in every court within the United States and its Territories and Possessions as they have by law or usage in the courts of such State, Territory or Possession from which they are taken.

156. Under the Court's Rooker-Feldman doctrine, federal district courts do not have jurisdiction to entertain federal claims that are "inextricably intertwined" with the merits of a judgment already rendered by a state court system, when the federal and state actions involve the same parties. See District of Columbia Court of Appeals v. Feldman, 460 U.S. 462, 486-87 (1983); Rooker v. Fidelity Trust Co., 263 U.S. 413, 415-16 (1923). The Court's Younger abstention doctrine keeps the federal courts from litigating federal questions at issue in ongoing state litigation, at least when the proceedings "implicate important state interests" and there is "an adequate opportunity in the state proceedings to raise [federal questions]." Middlesex County Ethics Comm'n v. Garden State Bar Ass'n, 457 U.S. 423, 431-32 (1982) (citing Younger v. Harris, 401 U.S. 37, 43-45 (1971)); see also Barry Friedman, Pas de Deux: The Supreme Court and the Habeas Courts, 66 S. CAL. L. REV. 2467, 2471 (1993) (rejecting the "full federal forum" theory because "the general fabric of federal jurisdiction as currently patterned does not offer the 
however, this theory is unhelpful because it envisions relitigation of all federal constitutional claims. It therefore provides no useful basis for deciding which constitutional claims should not be relitigated.

2. The Deterrence Model. This model sees federal habeas review primarily as a mechanism for ensuring that state actors-e.g., law enforcement officers, prosecutors, and judges-properly follow the dictates of federal constitutional law. ${ }^{157}$ In this view, habeas hangs like the sword of Damocles over the heads of these state actors, deterring them from violating the federal constitutional rights of persons who eventually become state prisoners. The Court relied on this rationale in Teague when it held that state prisoners could not avail themselves of favorable changes in federal constitutional law handed down after their state appeals ended, in part because state judges could not realistically be expected to apply (or be deterred from misapplying) federal law that had not yet been decided. ${ }^{158}$

The deterrence theory suffers from two major drawbacks, however: it has been criticized both as implying the incompetence of state actors and as being wholly ineffectual, since state actors are unlikely to change their behavior in light of the very small number of habeas petitions that are actually granted. ${ }^{159}$ Regardless of the merits of these criticisms, however, the deterrence model would surely mandate relitigation of almost every constitutional claim, since nearly every constitutional criminal procedure right serves to deter some state actorwhether it be the police officer who unlawfully searches a suspect, the prosecutor who inflames the jury, or the judge who misapplies $\mathrm{Su}$ -

\footnotetext{
opportunity to litigate every federal claim in a federal trial forum").

157. See Lee, supra note 105, at 197 ("[T] he proper question [in habeas] is whether the grant of relief in this type of case is likely to have some deterrent value against future constitutional violations."); McCord, supra note 5, at 778-79 (outlining the contours of what he refers to as the "inverse correlation vision" of habeas, which tracks the deterrence theory); Peller, supra note 5, at 668 (noting how federal habeas serves as a deterrent to state courts' misconstruing federal constitutional law). Even Justice Harlan has acknowledged this role of habeas. See Desist v. United States, 394 U.S. 244, 264 (1969) (Harlan, J., dissenting) (noting that "the threat of collateral attack may be necessary to assure that the lower federal and state courts toe the constitutional line").

158. See Teague v. Lane, 489 U.S. 288, 306-07 (1989) (plurality).

159. See supra note 131. While deterrence may be inappropriate as the touchstone for federal habeas, one must recognize that the existence of habeas review itself serves some deterrent purpose by providing additional review of state court actions. The point here is simply that a writ premised solely on the deterrence rationale is of questionable utility, not that deterrence should be abandoned entirely as a supplemental rationale.
} 
preme Court precedent. ${ }^{160}$ As a result, the deterrence theory is, like the full federal forum model, singularly unhelpful as a tool for distinguishing among constitutional claims.

3. The Guilt and Innocence Model. Under this view, federal habeas functions primarily as a backstop "to assure that no innocent person suffers an unconstitutional loss of liberty." 161 As this Article illustrates, innocence can potentially be used in several ways to narrow the substantive scope of the writ. Earlier in Part II, it was proposed that innocence be used as a tool to screen out individual habeas petitions-state prisoners able to make a "colorable showing of innocence" would be permitted to raise any constitutional claim, regardless of whether that claim was related to the evidence of their innocence. ${ }^{162}$ Here, by contrast, innocence is to be used as a tool to determine which constitutional claims may be raised by any habeas petitioner, even one who cannot make a "colorable showing of innocence." That is, the guilt and innocence model scrutinizes individual constitutional claims to determine whether they help secure the accuracy of the guilty verdict (or instead serve other values unrelated to guilt or innocence), and only those constitutional claims relevant to guilt or innocence are to be cognizable on habeas.

The Supreme Court, in a line of cases beginning with Stone v. Powell, ${ }^{163}$ started to explore a narrowing of the substantive scope of habeas using a variant of this model. In Stone, the Supreme Court held that habeas petitioners normally would no longer be permitted to assert claims based on the Fourth Amendment's exclusionary rule if the state courts provided "an opportunity for full and fair litigation of a Fourth Amendment claim." after "weighing the utility of the exclusionary rule against the costs of

160. See Chen, supra note 57, at 608-09 (noting that "two distinct elements to the deterrence argument" are "deter[ring] state judges from ignoring federal constitutional law in their decisionmaking" and "deter[ring] state and local law enforcement officials from constitutional transgressions"); Woolhandler, supra note 105, at 641 (claiming that persons "seeking habeas are generally seeking remedies for unredressed ad hoc denials of constitutional rights, inflicted by police, prosecutors, or the state courts").

161. Stone v. Powell, 428 U.S. 465, 491 n.31 (1976).

162. See supra Part II.A.2.

163. 428 U.S. 465 (1976).

164. Id. at 494. The Court said that, "where the State has provided an opportunity for full and fair litigation of a Fourth Amendment claim," the Constitution does not require that a state prisoner "be granted federal habeas corpus relief on the ground that evidence obtained in an unconstitutional search or seizure was introduced at his trial." Id. 
extending it to collateral review of Fourth Amendment claims" ${ }^{165}$ and finding that the "additional contribution, if any, of the consideration of search-and-seizure claims of state prisoners on collateral review [is] small in relation to the costs." ${ }^{166}$ In the course of reaching this conclusion, the Court expressed a somewhat narrower vision of habeas, noting that "[r]esort to habeas corpus, especially for purposes other than to assure that no innocent person suffers an unconstitutional loss of liberty, results in serious intrusions on values important to our system of government." ${ }^{167}$ Unsurprisingly, Justices Brennan and Marshall in dissent regarded the majority's opinion as "portend[ing] substantial evisceration of federal habeas corpus jurisdiction."

As it turns out, however, their prediction was wrong, and the Court turned away several subsequent attempts to extend Stone to other claims. In Rose v. Mitchell, ${ }^{169}$ the Court concluded that "discrimination in the selection of the grand jury differs so fundamentally from application on habeas of the Fourth Amendment exclusionary rule that the reasoning of Stone v. Powell should not be extended to foreclose habeas review of such claims in federal court." ${ }^{, 170}$ In Jackson

\footnotetext{
165. Id. at 489.

166. Id. at 493; accord id. ("There is no reason to believe ... that the overall educative effect of the exclusionary rule would be appreciably diminished if search-and-seizure claims could not be raised in federal habeas corpus review of state convictions."). The Court was careful to point out, however, that this new limitation on habeas was equitable, not jurisdictional. See id. at 495 n.37 ("Our decision does not mean that the federal court lacks jurisdiction over such a claim, but only that the application of the rule is limited to cases in which there has been both such a showing [i.e., of no opportunity for litigating the Fourth Amendment claim in state court] and a Fourth Amendment violation.").

167. Id. at $491 \mathrm{n} .31$.

168. Id. at 503 (Brennan, J., dissenting); see also Friedman, Two Habeas, supra note 1, at 284 ("For a number of reasons ... Stone cannot be read simply as a Fourth Amendment case."); Steiker, Incorporating, supra note 82, at 919 ("Powell is better read as a limitation on habeas than as a gloss on the exclusionary rule.").

169. 443 U.S. 545 (1979).

170. Id. at 560-61. The majority reasoned that the equal protection claim in Rose involved a "personal constitutional right," while the exclusionary rule at issue in Stone was merely "a judicially created remedy." Id. at 562. It also observed that "the concern with judicial integrity is of much greater concern in grand jury discrimination cases." Id. at 563. This concern played a "limited role" in Stone. Stone v. Powell, 428 U.S. 465, 485 (1976). Finally, the majority fell back on the naked proposition that "the constitutional interests that a federal court adjudicating a claim on habeas of grand jury discrimination seeks to vindicate are substantially more compelling than those at issue in Stone." Rose, 443 U.S. at 564. The Court gave no weight to the fact that grand jury discrimination has little to do with the accuracy of the guilty verdict at trial. See $i d$. at 560 (noting that Stone said it was limited to the exclusionary rule context). In addition, the Court cited the fact that the trial court itself could not police its own violations, that federal courts have granted relief for such discrimination for over one hundred years, and that the costs
} 
v. Virginia, ${ }^{171}$ decided the same Term as Rose, the Court held that the newly announced due process right to sufficiency of the evidence review could be raised on federal habeas notwithstanding Stone, mostly notable because "[t]he question whether a defendant has been convicted upon inadequate evidence is central to the basic question of guilt or innocence," which Stone had held was the touchstone purpose of habeas. ${ }^{172}$ In Kimmelman v. Morrison, ${ }^{173}$ the Court found that Sixth Amendment claims of ineffective assistance of counsel relating to Fourth Amendment claims were cognizable. ${ }^{174}$

In the 1993 case of Withrow v. Williams, ${ }^{175}$ the Court wrote what may be the last chapter in the story of Stone. By a 5-4 margin, the Withrow Court held that, with respect to claims arising under Miranda v. Arizona, Stone should not be extended. ${ }^{176}$ Justice Souter's majority opinion distinguished Stone on three grounds. First, he noted that Miranda, while "prophylactic," nevertheless "safeguard[ed] 'a fundamental trial right" - namely, the Fifth Amendment's privilege against self-incrimination. ${ }^{177}$ By contrast, the exclusionary rule protected against violations of the Fourth Amendment, which are usually committed by law enforcement officers and are therefore "wholly ex-

of granting habeas relief were less than in the Stone context because, on retrial, probative evidence would not have to be excluded. See id. at 561-64.

171. 443 U.S. 307 (1979).

172. Id. at 323; accord infra note 184 (quoting Stone on the purpose of habeas). In recognizing this new claim on habeas, the Court also observed that such claims would not "create an entirely new class of cases cognizable on federal habeas corpus," because they resembled other claims already cognizable, and noted that the general costs of habeas in terms of "finality and federal-state comity" were not reasons in themselves not to recognize a constitutional claim on habeas. $I d$. at 321-22.

173. 477 U.S. 365 (1986).

174. See id. at 365. In reaching its holding, the Court noted that Stone involved a "judicially created structural remedy" and not a "personal constitutional right." Id. at 375-76. While the Court did not assess whether the right to counsel (and the concomitant right to effective assistance) helped guarantee the accuracy of the guilty verdict, the majority nevertheless repeatedly stressed that the right to counsel was essential to the "fairness, and thus the legitimacy, of our adversary process." Id. at 374; see also id. at 377 (recognizing how the right to counsel assures "a fair trial itself"). The Court also held that recognizing the right to counsel on habeas was important because "collateral review will frequently be the only means through which an accused can effectuate the right to counsel." Id. at 378. Of course, ineffective assistance claims that could not be raised in state court would be cognizable even under Stone's rule, because petitioners asserting such claims would not have had a "full and fair opportunity" to present them in state proceedings. The Kimmelman majority did not acknowledge or account for the fact that Stone already preserved review in these circumstances.

175. 507 U.S. 680 (1993).

176. See id. at 691 .

177. Id. (quoting United States v. Verdugo-Urquidez, 494 U.S. 259, 264 (1990)). 
trajudicial." 178 Second, Justice Souter observed that the Fifth Amendment often enhances the accuracy of the guilty verdict, which is undermined when a coerced confession is introduced. ${ }^{179}$ Finally, Justice Souter noted that withdrawal of habeas review for Miranda claims would be unlikely to "benefit the federal courts" because those claims would probably be recast as violations of the due process protection against coerced confessions. ${ }^{180}$

As the above discussion indicates, the Supreme Court in these cases did not use a constitutional claim's relation to the accuracy of a defendant's guilty verdict as the sole basis for deciding whether a particular constitutional claim would be cognizable on habeas. In Stone itself, the Court made clear that even Fourth Amendment claims normally excluded from review on habeas could be raised if a particular defendant did not have a "full and fair opportunity" to litigate the claim in state court. ${ }^{181}$ In this regard, Stone reflects a blending of

178. Id.
179. See id. at 692 .
180. Id. at 693 . Justice O'Connor was not convinced, and she dissented with Chief Justice

180. Id. at 693. Justice O'Connor was not convinced, and she dissented with Chief Justice
Rehnquist. Justice O'Connor agreed with Justice Souter that the Fifth Amendment's selfincrimination protection was a "fundamental trial right" that, when violated, could undermine the accuracy of the guilty verdict. Id. at 705 (O'Connor, J., dissenting). However, she found that fact entirely beside the point, since the issue was not whether to exclude from habeas review claims arising under the Fifth Amendment, but whether to exclude confessions obtained in violation of Miranda's prophylactic rule, which excludes from trial any confessions-voluntary or involuntary-obtained without the benefit of Miranda's now-familiar warnings. See id. (O'Connor, J., dissenting) ("The Court's spirited defense of the Fifth Amendment is, of course, entirely beside the point."). Indeed, because Fifth Amendment claims would remain available to state prisoners on habeas, continued review of Miranda claims on habeas would in effect secure relief "only in those cases in which the prisoner's statement was neither compelled nor involuntary." Id. at 706 (O'Connor, J., dissenting). As a result, Justice O'Connor reasoned, excluding claims based on failure to give Miranda warnings from federal collateral review would not undermine the accuracy of the guilty verdict or rob petitioners of the right to assert any fundamental trial rights. See id. at 706-07 (O'Connor, J., dissenting). She also found unpersuasive Justice Souter's argument that excluding Miranda claims would be ineffectual because those claims would be rewritten as due process claims. See id. at 708-09 (O'Connor, J., dissenting). Due process claims, she explained, "require coercive state action," which she argued was much more difficult to establish than the simple failure to give Miranda warnings. Id. (O'Connor, J., dissenting).

Justice Scalia dissented separately, with Justice Thomas, chastising the majority and Justice O'Connor for overlooking what he considered to be the most salient point- that "Williams has already had full and fair opportunity to litigate this claim [in state court]." Id. at 715 (Scalia, J., dissenting). Justice Scalia went on to explain why Professor Bator's "full and fair" opportunity approach, with exceptions for claims "go[ing] to the fairness of the trial process or to the accuracy of the ultimate result," should be the appropriate guide. Id. at 718-20 (Scalia, J., dissenting).

181. See Stone v. Powell, 428 U.S. 465, 489 (1976) (framing the question presented as 
the guilt and innocence model and the "full and fair" opportunity approach to habeas. ${ }^{182}$

Stone and its progeny were also not uniform in treating guilt as their guiding light. ${ }^{183}$ To be sure, the Court in Stone specifically explained why the Fourth Amendment's exclusionary rule did not relate to the defendant's guilt and often obfuscated the search for truth. ${ }^{184}$ Similarly, in Jackson, the Court explained why a constitutional claim relating to the sufficiency of evidence was appropriately litigated on habeas because it was intimately related to the question of the defendant's guilt. ${ }^{185}$ However, in Kimmelman, Rose, and Withrow, the Court seemingly gave little weight to the fact that the Sixth Amendment right to counsel, the Fourteenth Amendment protection against discriminatory selection of the grand jury, and Miranda's prophylactic exclusionary rule often have no bearing on the defendant's guilt. ${ }^{186}$

In addition, the Court in these opinions often referred to other considerations aside from a claim's relationship to the question of guilt when deciding whether a claim could be relitigated on federal habeas. In nearly every post-Stone opinion, the Court purported to

"whether state prisoners-who have been afforded the opportunity for full and fair consideration ... by the state courts at trial and on direct review - may invoke their claim again on federal habeas corpus review" (emphasis added)).

182. See supra Part II.A.1; see also Cover \& Aleinikoff, supra note 82, at 1077-78 (criticizing Stone for relying on both theories); Friedman, Two Habeas, supra note 1, at 277-79 (observing how Stone relied on both Professor Bator's "corrective process" theory and Judge Friendly's "guilt-related" theory); Peller, supra note 5, at 602 (criticizing Stone for relying on both theories, which are "fundamentally divergent").

183. See Friedman, Two Habeas, supra note 1, at 280-86 (noting inconsistencies between Stone and Jackson on the one hand, and Rose and Kimmelman on the other).

184. See Stone, 428 U.S. at 489-90 ("The costs of applying the exclusionary rule . . are well known: the focus of the trial, and the attention of the participants therein, are diverted from the ultimate question of guilt or innocence that should be the central concern in a criminal proceeding.").

185. See Jackson v. Virginia, 443 U.S. 307, 323 (1979) ("The question whether a defendant has been convicted upon inadequate evidence is central to the basic question of guilt or innocence.").

186. See Kimmelman v. Morrison, 477 U.S. 365, 380 (1986):

[W]e have never intimated that the right to counsel is conditioned upon actual innocence. The constitutional rights of criminal defendants are granted to the innocent and the guilty alike. Consequently, we decline to hold either that the guarantee of effective assistance of counsel belongs solely to the innocent or that it attaches only to matters affecting the determination of actual guilt.

See also Rose v. Mitchell, 443 U.S. 545, 560-61 (1979) (distinguishing Stone's concern with accuracy of the guilty verdict by seemingly confining Stone to its facts); $c f$. Withrow v. Williams, 507 U.S. 680, 692 (1993) (reasoning that Miranda ensures reliability of confessions, at least when the confessions are obtained in violation of the Fifth Amendment). 
distinguish Stone on the ground that the Fourth Amendment's exclusionary rule was a judicially created remedy instead of a "personal constitutional right." ${ }^{\text {187 }}$ This distinction has little to do with accuracy of the guilty verdict, and it is particularly disingenuous as a basis for contrasting Miranda, as Miranda itself announced a judicially created exclusionary rule. ${ }^{188}$ Indeed, the case for not applying Miranda's exclusionary rule on habeas may be more compelling than the argument for excluding the Fourth Amendment's, since Miranda's rule may apply in situations where there is not an underlying constitutional violation. ${ }^{189}$ The Court has also treated a constitutional claim's relationship to judicial integrity inconsistently. In Stone, the Court downplayed the importance of judicial integrity, while in Rose the Court found it to be "of much greater concern." these and other factors undercuts the rationality of the Court's approach to picking and choosing among constitutional claims. ${ }^{191}$

187. Rose, 443 U.S. at 561-62 (distinguishing the exclusionary rule in Stone on the ground that it was a "judicially created remedy rather than a personal constitutional right" (citation and internal quotations omitted)); see also Withrow, 507 U.S. at 691 (contrasting Miranda with the Fourth Amendment exclusionary rule because the former "safeguards a fundamental trial right," while the latter involves a "wholly extrajudicial Fourth Amendment violation" (internal citation and quotation omitted)); Kimmelman, 477 U.S. at 377 (noting that the Sixth Amendment right to counsel was a "personal" and "fundamental right" relevant to "trial").

188. See Miranda v. Arizona, 384 U.S. 436, 492 (1966) ("Without these warnings the statements were inadmissible.").

189. Even Professor Peller, an advocate for broad habeas review, acknowledges the illogic of the Court's precedent on this point. See Peller, supra note 5, at 600 ("Moreover, the Court's suggestion that the distinction between Rose and Stone turns on the difference between personal and judicially created remedies is inexplicable since the Court also stated that the accused's right to reversal on direct review was a right accorded for auxiliary social purposes.").

190. Rose, 433 U.S. at 563. But cf. Stone, 428 U.S. at 485 (downplaying the value put on judicial integrity).

191. Other factors the Court has cited on occasion include: (i) whether application of the constitutional right at issue on habeas is likely to deter future violations, compare Stone, 428 U.S. at 486, 492 (reasoning that police are less likely to be deterred because the Fourth Amendment exclusionary rule is applied on habeas), with Rose, 443 U.S. at 563 (concluding that habeas review of grand jury discrimination claims will deter such discrimination); (ii) whether recognizing the constitutional claim on habeas will drain judicial resources, compare Withrow, 507 U.S. at 693 (reasoning that exclusion of Miranda claims on habeas will not reduce the judicial burden because those claims will be recast as due process violations) and Jackson v. Virginia, 443 U.S. 307, 322 (1979) (recognizing that sufficiency of the evidence claims have long been heard on federal habeas and rarely require hearings), with Stone, 428 U.S. at 491 n.31 (identifying the drain on judicial resources from rehearing claims unrelated to guilt); and (iii) whether the constitutional claim has been around for several years, see Rose, 443 U.S. at 562 (emphasizing that grand jury discrimination claims have been litigated in federal court for over one hundred years). 
Even a more "pure" version of the guilt and innocence model would still not provide a workable basis for distinguishing among constitutional claims. First, and perhaps most fatally, this approach presupposes that constitutional claims can be distinguished on the basis of whether they serve to enhance the accuracy of the underlying guilty verdict. But, as many commentators have noted, constitutional rights usually serve several purposes, depending upon the situation in which they are applied. ${ }^{192}$ Miranda, for example, enhances the reliability of custodial confessions, but when a confession is coerced, Miranda also protects the accuracy of the guilty verdict. As this example illustrates, because many constitutional rights at one time or another are relevant to the defendant's guilt or innocence, this approach is also unlikely to screen out an appreciable number of constitutional claims. ${ }^{193}$ Finally, as mentioned above, several constitutional guarantees are geared toward ensuring procedural regularity regardless of the outcome. ${ }^{194}$ Using the determination of guilt and innocence as the sole basis for sifting through constitutional claims would likely exclude from habeas review procedurally focused rights, notwithstanding the Court's repeated statements that they are often among the most basic of the constitutional rights. ${ }^{195}$ There is accordingly a good argument that a writ defined in this manner may go too far. For all these reasons, the guilt and innocence approach does not provide the best foundation for a leaner writ of habeas corpus.

4. The Appellate Model. Grounded in legal pragmatism, the appellate model of habeas pays close attention to how the federal habeas writ actually functions in the courts today. Proponents of this model, including Professors Barry Friedman and James Liebman, begin by noting that habeas looks far more like an appeal than the

192. See, e.g., Cover \& Aleinikoff, supra note 82, at 1093 (noting that "most constitutional rights do not fit neatly into the category of truth-furthering or truth-obstructing [rights]"); Peller, supra note 5, at 664 (stressing that "constitutional rights vindicate diverse values").

193. See Lee, supra note 105, at 196 (claiming that "constitutionally-mandated procedures that are not aimed at safeguarding against mistakes in the determination of guilt are exceptional and, for the most part, notable"); Yeager, supra note 50, at 696 n.172 ("[A]ny categorical rule that would exempt from preclusion or forfeit claims only tenuously related to accuracy would be far too capacious to trim habeas in the name of accuracy; it would trim nothing.").

194. See supra notes 114, 186. That is not to say, however, that guilt and innocence should be irrelevant. See Hoffmann \& Stuntz, supra note 50, at 88 (maintaining that "constructing the law of habeas without a reference to innocence and guilt means ignoring the central point of the criminal justice system"); see also infra Part III.A.

195. See supra text accompanying notes 62-67 (citing to "structural error" cases). 
original civil action it technically is. ${ }^{196}$ Unlike most civil actions, habeas is not subject to the general rule of res judicata that would otherwise preclude a collateral attack on a state judgment of conviction. ${ }^{197}$ Also unlike other original actions, habeas proceedings are intimately related to prior state adjudications- to what factual and legal findings the state courts made and to whether the habeas petitioner properly raised a claim, to name a pair of examples. ${ }^{198}$ Indeed, this close tie often precludes the habeas litigant-unlike most civil litigants-from developing a new factual record at a hearing in federal court. ${ }^{199}$

By contrast, many aspects of federal habeas review make it look like a final layer in a single process of appellate review that begins in state court after a conviction is handed down and ends with federal habeas. ${ }^{200}$ First, the relevant substantive law for habeas purposesthat is, federal constitutional law-is the same both in the state courts and on federal habeas review due to incorporation. ${ }^{201}$ Second, the

196. See Friedman, Two Habeas, supra note 1, at 261 ("Habeas must be seen . . a as an appeal to a federal forum available in every state criminal case."); $i d$. at 254 (noting that habeas review in the district courts acts as a "surrogate for the United States Supreme Court . . . executing appellate jurisdiction over state criminal proceedings"); Liebman, supra note 109, at 2055 ("Since 1789, however, the federal writ of habeas corpus has provided statutorily specified classes of prisoners with a limited and substitute federal writ of error or appeal as of right."); McCord, supra note 5, at 838 ("There were then, and still are, many significant areas of habeas jurisprudence that can be explained by the appellate review vison.”).

197. Compare 28 U.S.C. $\S 1738$ (1994) (providing that state court decisions "shall have the same full faith and credit in every court within the United States and its Territories and Possessions as they have by law or usage in the courts of such State, Territory, or Possession from which they are taken”), with Brown v. Allen, 344 U.S. 443, 458 (1953) (recognizing that state court decisions are not res judicata in federal habeas review).

198. See Liebman, supra note 109, at 2088 (arguing that habeas actions "are affected by prior judicial proceedings far too frequently to qualify as truly separate or 'original' actions").

199. See 28 U.S.C. $§ 2254$ (e)(2) (Supp. III 1997) (permitting habeas petitioners to have a hearing to develop the factual basis for their claims only under certain circumstances); Williams v. Taylor, 120 S. Ct. 1495 (2000) (holding that § 2254(e)(2)'s tighter standards governing when an evidentiary hearing is appropriate apply only if a habeas petitioner was not diligent or was otherwise somehow at fault in developing the factual basis for his claim in state court); Keeney v. Tamayo-Reyes, 504 U.S. 1, 11 (1992) (holding that a habeas petitioner's failure to develop the factual basis for a claim in state court would be overcome only if the petitioner established "cause" and "prejudice" or that the failure to hold a hearing would be a "fundamental miscarriage of justice").

200. See Susan Bandes, Simple Murder: A Comment on the Legality of Executing the Innocent, 44 BUFF. L. REV. 501, 523 (1996) ("[I]t is important to view the entire criminal justice system-state and federal—as a system, and not a series of independent institutions.").

201. See Hoffmann \& Stuntz, supra note 50, at 79 (claiming that "federal law today serves as a floor and a ceiling and everything in between: federal law dictates, often in minute detail, the course of state criminal proceedings"); see also supra note 138 (detailing the Constitution's 
procedural mechanisms that govern appellate practice have nearly identical analogues to the procedural doctrines that control habeas review. State appellants are usually required to preserve errors at trial or in earlier appeals before raising them at the next stage of the state appellate review process. ${ }^{202}$ Similarly, habeas petitioners are required by the exhaustion and procedural default doctrines to demonstrate that they raised their constitutional claims in the state courts before raising them again on habeas. ${ }^{203}$ State appellants are permitted only one appeal; habeas petitioners are, for most intents and purposes, also permitted to file only one federal petition. ${ }^{204}$ Finally, the stan-

transformation into a national code of criminal procedure).

202. Most states require timely preservation of error. For example, defendants must usually object to jury instructions before the jury retires to consider the verdict. See, e.g., ARIZ. R. CRIM. P. 21.3(c); COLO. R. CRIM. P. 30; FlA. R. CRIM. P. 3.390(d); ILl. R. CRIM. P. 451(b). They must also make timely objections to the introduction of evidence, see, e.g., COLO. R. EVID. 103(a)(1), and timely requests for a new trial, see, e.g., COLO. R. CRIM. P. 35.

203. See Coleman v. Thompson, 501 U.S. 722, 750 (1991):

In all cases in which a state prisoner has defaulted his federal claims in state court pursuant to an independent and adequate state procedural rule, federal habeas review of the claims is barred unless the prisoner can demonstrate cause for the default and actual prejudice as a result of the alleged violation of federal law, or demonstrate that failure to consider the claims will result in a fundamental miscarriage of justice.

Usually, a habeas petitioner who fails to exhaust his state claims before proceeding in federal court will not be able to satisfy state procedural rules when he returns to state court to exhaust his claims. See id. at 735 n.* (finding that a default had occurred when "the petitioner failed to exhaust state remedies and the [state] court to which petitioner would be required to present his claims in order to meet the exhaustion requirement would now find the claims procedurally barred"); see also Liebman, supra note 109, at 2094-95 ("Via the exhaustion doctrine, the Court recently has assured that habeas corpus petitioners, like direct appellants, cannot seek the reviewing court's consideration before seeking the prior court's judgment."); supra Part I.

204. Constitutional claims raised in subsequent habeas petitions usually fall into one of two categories. In the first category are the claims that were asserted and litigated in a prior habeas petition. These claims are called "successive claims" and are barred in subsequent petitions unless "the prisoner supplements his [successive] constitutional claim with a colorable showing of factual innocence." Kuhlmann v. Wilson, 477 U.S. 436, 454 (1986). But see Sawyer v. Whitley, 505 U.S. 333, 339 (1992) (characterizing Kuhlmann as also permitting a prisoner to show "cause" and "prejudice" in addition to innocence). The second category consists of those claims that could have been raised (but were not) in previously filed habeas petitions. These claims are referred to as "abusive claims" and are barred unless the petitioner satisfies the same "cause" and "prejudice" standard used to overcome procedural defaults. See McCleskey v. Zant, 499 U.S. 467, 493 (1991).

In 1996, Congress altered both the procedural and substantive prerequisites to be met before a "second or successive" petition could be filed in the federal courts. Successive petitions now appear to be barred under all circumstances. See 28 U.S.C. § 2244(b)(1) (Supp. III 1997) ("A claim presented in a second or successive habeas corpus application under $\$ 2254$ that was presented in a prior application shall be dismissed."). Abusive petitions, in contrast, are barred unless the late-asserted claim relies on a new rule of law made retroactive by the Supreme Court or rests on new facts that could not have been previously discovered and that would likely exon- 
dards of review used by state courts in reviewing the findings of lower tribunals were, until recently, identical to the standards of review used by habeas courts in reviewing the findings of state courts: findings of fact were given deference, while legal findings or findings involving mixed questions or law and fact were reviewed de novo. ${ }^{205}$

In fact, the Supreme Court has implicitly acknowledged that habeas review in some respects serves as a substitute for direct review that the Court itself cannot conduct given its limited resources. ${ }^{206}$ Congress buttressed this view when it amended the statutory writ to make Supreme Court adjudication of an issue on direct review conclusive in subsequent habeas review, which seemingly indicates Congress's view that habeas review is necessary only when the Supreme Court has not reviewed an issue. ${ }^{207}$ To be sure, the Court has repeatedly admonished that "habeas corpus is not intended as a substitute for appeal. ${ }^{208}$ In fact, federal habeas review that takes place at the conclusion of the state appellate process is not a substitute for an appeal: it is arguably an extension of the appellate process.

erate the habeas petitioner of his underlying guilt. See id. $\S 2244$ (b)(2). Procedurally, a habeas petitioner must now ask the court of appeals for permission to file any "second or successive" petition in district court, which can only be granted by the court of appeals if the statute's requirements are met. See id. §2244(b)(3) (setting forth this "gatekeeper" mechanism).

205. See supra note 55 .

206. See Brown v. Allen, 344 U.S. 443, $456-57$ (1953) (holding that a denial of certiorari on direct review does not have conclusive weight on habeas, because giving denials such weight would essentially shut down habeas review, given the Court's inability to review the merits of many cases on direct review); see also Chemerinsky, supra note 5, at 755 ("If there was to be federal court review of state court procedures, it would have to be undertaken primarily in the district courts through habeas corpus [instead of by the Supreme Court through direct review]."); Friedman, Two Habeas, supra note 1, at 274 ("At the heart of the Brown Court's decision to expand the scope of federal habeas, therefore, was its realization that direct review alone no longer could provide adequate treatment of federal questions arising in state criminal cases.").

207. See 28 U.S.C. $§ 2244(c)$ :

In a habeas corpus proceeding brought in behalf of a person in custody pursuant to the judgment of a State court, a prior judgment of the Supreme Court of the United States on an appeal or review by a writ of certiorari at the instance of the prisoner of the decision of such State court, shall be conclusive as to all issues of fact or law with respect to an asserted denial of a Federal right which constitutes ground for discharge in a habeas corpus proceeding, actually adjudicated by the Supreme Court therein....

208. Jackson v. Virginia, 443 U.S. 307, 333 n.5 (1979) (Stevens, J., concurring); accord Townsend v. Sain, 372 U.S. 293, 311 (1963) ("The whole history of the writ-its unique development-refutes a construction of the federal courts' habeas corpus powers that would assimilate their task to that of courts of appellate review. The function on habeas is different."); Sunal v. Large, 332 U.S. 174, 178 (1947) ("So far as convictions obtained in the federal courts are concerned, the general rule is that the writ of habeas corpus will not be allowed to do service for an appeal."). 
Federal habeas review is not identical to an appeal, however. Unlike an appellate court, a habeas court is not confined to the facts developed in the record below, and it may hold a hearing to receive new facts when necessary to evaluate the merits of certain claims. ${ }^{209}$ Congress's recent alteration of the standards by which federal habeas courts now evaluate the findings of state courts on issues involving legal questions may also distinguish habeas from a direct appeal. A petition may now be granted only if the state adjudication "resulted in a decision that was contrary to, or involved an unreasonable application of, clearly established Federal law, as determined by the Supreme Court of the United States." 110 The Supreme Court recently held that this language requires a federal habeas court to defer to a state court's reasonable interpretations of federal law, even if the habeas court would have reached a different conclusion "in its independent judgment." ${ }^{211}$

In the same vein, the Court in Brecht v. Abrahamson ${ }^{212}$ changed the standard governing when federal habeas courts can grant relief. ${ }^{213}$ No longer can federal courts use the same harmless error test used by courts on direct appeal. ${ }^{214}$ Under Brecht, once a constitutional violation has been established, habeas courts can grant relief only if it is shown that the error "'had substantial and injurious effect or influence in determining the jury's verdict.","215

In addition, the rules that require errors to be preserved on appeal are in some ways distinguishable from the procedural default doctrine applicable on habeas. The former usually brook no exceptions, while the procedural default doctrine will excuse the failure to preserve for petitioners able to demonstrate "cause" and "prejudice," or their probable innocence. ${ }^{216}$ All of these differences reflect that, while largely similar to an appeal, federal habeas review nevertheless serves other values.

209. See 28 U.S.C. $\$ 2246$ (1994) ("On application for a writ of habeas corpus, evidence may be taken orally or by deposition, or, in the discretion of the judge, by affidavit."); see also id. $\S$ 2254(e) (setting forth standards for when a factual hearing is warranted).

210. 28 U.S.C. $\$ 2254(d)(1)$.

211. Williams v. Taylor, 120 S. Ct. 1495, 1522 (2000); see also supra text accompanying notes 57-60.

212. 507 U.S. 619 (1993).

213. See McCord, supra note 5, at 834 (calling Brecht a "disaffirmation of the appellate review vision").

214. See supra notes 70-75 and accompanying text.

215. Brecht, 507 U.S. at 631 (quoting Kotteakos v. United States, 328 U.S. 750, 776 (1946)).

216. See Kuhlmann v. Wilson, 477 U.S. 436, 454 (1986). 
Most proponents of the appellate model argue that, if habeas functions as an appeal in the real world, that analogy should be extended to confer upon the federal habeas courts the same breadth in the claims they review as that exercised by the state appellate courts. ${ }^{217}$ Because the state appellate courts review all federal constitutional claims, these proponents reason, federal habeas courts should do the same. This syllogism regarding the scope of federal habeas under the appellate model, while tidy, overlooks two salient points. First, the scope of habeas review is already different from the scope of state appellate review. Congress, perhaps recognizing the danger of federal court review of purely state law issues, precluded federal habeas courts from reviewing statutory and constitutional issues based on state law, even though they may be raised on direct appeal in state court. ${ }^{218}$ Second, as discussed above, while the analogy between federal habeas and direct appeal is a strong one, it is not perfect. ${ }^{219}$ Because the appellate model is premised in large part upon the strength of the descriptive analogy between habeas review and appellate review, weaknesses in the analogy make automatic importation of appellate procedures-including the scope of review-into the habeas context inappropriate. With this type of hybrid descriptive/normative model, due consideration must be given to the actual differences between state appellate review and habeas-namely, that habeas review is conducted by courts of a different sovereign and that habeas review serves a more limited function than error correction.

Consequently, the "pure" appellate model is unhelpful in the search for criteria by which to evaluate constitutional claims because it would permit review of all such claims and because it fails to recognize that habeas is both more and less than a typical state appeal. The appellate model nevertheless closely represents how the federal writ currently functions today.

217. See Friedman, Two Habeas, supra note 1, at 286-87 ("Because any federal claim preserved in state court proceedings may be raised on direct review, any such claim should also be subject to federal habeas review."); cf. Liebman, supra note 109, at 2056 ("As a substitute for federal direct appeal, habeas corpus has never duplicated, but has always mirrored the scope of, Supreme Court review on direct appeal.").

218. See Estelle v. McGuire, 502 U.S. 62, 67 (1991) ("We have stated many times that "federal habeas corpus relief does not lie for errors of state law"" (quoting Lewis v. Jeffers, 497 U.S. 764, 780 (1990)); cf. Liebman, supra note 109, at 2009 ("Habeas petitioners have access to a limited form of appellate review. The review is 'limited' because only issues arising under the national constitution, laws, and treaties are cognizable.").

219. See Liebman, supra note 109, at 2005 ("[T] he two modes of review are not identical .... [but have] rather modest differences."). 
5. The "Fundamental Fairness" Model. This model views federal habeas as a means of ensuring that state prisoners are afforded some minimum quantum of fairness, without which their continued incarceration would be "fundamentally unfair." Over the years, the Supreme Court has called upon this theory to justify both the expansion-and the contraction-of the federal writ. In fact, three different versions of this theory seem to have emerged.

In the 1960s, the Court latched onto a very expansive variant of this theory that allowed state prisoners to revisit nearly any federal constitutional claim, regardless of what had happened in earlier state proceedings. ${ }^{220}$ In Fay v. Noia, ${ }^{221}$ for example, Justice Brennan's majority opinion started from the premise that "if [a prisoner's] imprisonment cannot be shown to conform with the fundamental requirements of law, the individual is entitled to his immediate release." ${ }^{222}$ The Court in Fay went on to rely in part upon this rationale in requiring federal habeas courts to ignore most procedural defaults. ${ }^{223} \mathrm{In}$ the same vein, in Townsend v. Sain, ${ }^{224}$ Chief Justice Warren held that the writ's function "as an efficacious and imperative remedy for detentions of fundamental illegality" dictated that the Court confer upon habeas courts a near-plenary power to hold evidentiary hearings. ${ }^{225}$

In the 1980s and 1990s, a majority of the Court began to espouse a far more limited version of this theory, primarily by stressing the "fundamental" aspect of the formulation. In Engle v. Isaac, ${ }^{226}$ Justice O'Connor wrote for the majority that "the writ is a bulwark against convictions that violate "fundamental fairness,",227 and then held-in

220. This expansive view of "fundamental fairness" was not confined to the 1960s and 1970s. For example, in the 1990s, Justice Blackmun argued that a "'fundamental miscarriage of justice' occurs whenever a conviction or sentence is secured in violation of a federal constitutional right." Sawyer v. Whitley, 505 U.S. 333, 352 (1992) (Blackmun, J., concurring).

221. 372 U.S. 391 (1963).

222. Id. at 402 .

223. See id. at 438 (recognizing a "limited discretion" for federal judges to overlook procedural defaults in state courts if a petitioner "has deliberately by-passed the orderly procedure of the state courts and in so doing has forfeited his state court remedies").

224. 372 U.S. 293 (1963).

225. Id. at 311; see also id. at 312 ("State prisoners are entitled to relief on federal habeas corpus only upon proving that their detention violates the fundamental liberties of the person, safeguarded against state action by the Federal Constitution.").

226. 456 U.S. 107 (1982).

227. Id. at 126 (quoting Wainwright v. Sykes, 433 U.S. 72, 97 (1977) (Stevens, J., concurring)). 
contradiction to Fay-that procedural defaults in state courts would not be examined during federal habeas review unless a petitioner demonstrated "cause" and "prejudice" or her probable innocence. ${ }^{228}$

In two 1986 companion cases, the Court elaborated on the exception to procedural default for "fundamental miscarriages of justice" and held that the exception applied only where the state prisoner could show that she was probably "actually innocent." 229 The Court explicitly "reject[ed] the suggestion that there is anything 'fundamentally unfair' about enforcing procedural default rules in cases devoid of any substantial claim that the alleged error undermined the accuracy of the guilt or sentencing determination." ${ }^{230}$ The Court similarly adhered to the accuracy-based notion of "fundamental fairness" in Teague v. Lane, ${ }^{231}$ when it held that only watershed rules of criminal procedure "without which the likelihood of an accurate conviction is seriously diminished" could be applied retroactively to habeas petitioners. ${ }^{232}$ Mirroring its holdings in the habeas context, the Court in Medina v. California ${ }^{233}$ held that state procedures in criminal cases would be struck down under the Due Process Clause only for "fundamental unfairness" 234 and confirmed that, "[i]n the field of criminal law, we have 'defined the category of infractions that violate "fundamental fairness" very narrowly.",

Justice Stevens has steadily developed a third view of "fundamental fairness." Taking a slightly different tack from the Courts of the 1960s and the 1980s, Justice Stevens has acknowledged that some constitutional rights are more fundamental than others-that is, that the violation of some rights is "important enough to require reversal

228. See id. at 129 .

229. Smith v. Murray, 477 U.S. 527, 537 (1986); accord Murray v. Carrier, 477 U.S. 478, 496 (1986) (companion case).

230. Smith, 477 U.S. at 538-39.

231. 489 U.S. 288, 313 (1989) (plurality).

232. Id. at 313. This accuracy-based notion of "fundamental fairness" is not unlike the "guilt/innocence" approach to sifting through constitutional claims first espoused in Stone. See supra Part II.B.3.

233. 505 U.S. 448 (1992).

234. Id. at 448. This was a departure from the standard used to evaluate state procedures in civil cases announced in Mathews v. Eldridge, 424 U.S. 319 (1976). Under Mathews, the Court employs a more liberal balancing test that examines: (i) "the private interest that will be affected by the official action;" (ii) "the risk of erroneous deprivation of such interest through the procedures used;" and (iii) "the Government's interest, including the function involved and the fiscal and administrative burdens that the additional or substitute procedural requirement would entail." Id. at 335 .

235. Medina, 505 U.S. at 443 (quoting Dowling v. United States, 493 U.S. 342, 352 (1990)). 
on direct appeal but do[es] not reveal the kind of fundamental unfairness to the accused that will support a collateral attack on a final judgment," while other rights are "so fundamental that [their violation] infect[s] the validity of the underlying judgment itself, or the integrity of the process by which that judgment was obtained." ${ }^{236}$ Given this hierarchy, Justice Stevens has argued that habeas should be limited to constitutional claims implicating fundamental fairness—such a standard, in Justice Stevens's view, would be preferable to current jurisprudence, which theoretically allows for the possibility of reviewing all claims while actually determining if habeas is available based on "the procedural history underlying" a constitutional claim. ${ }^{237} \mathrm{By}$ acknowledging that habeas might not be open as an avenue of relief for all federal constitutional violations, Justice Stevens's view of "fundamental fairness" is narrower than the Warren Court's. ${ }^{238}$ At the same time, Justice Stevens has opined that "[o]ur criminal justice system, and our Constitution, protect other values in addition to the reliability of the guilt or innocence determination," so that "the [Rehnquist] Court's exaltation of accuracy as the only characteristic of "fundamental fairness' is deeply flawed." 239 As a result, Justice Stevens views

236. Rose v. Lundy, 455 U.S. 509, 543-44 (1982) (Stevens, J., dissenting); accord Brecht v. Abrahamson, 507 U.S. 619, 640 (1993) (Stevens, J., concurring) (noting how "collateral relief [has been confined] to cases that involve fundamental defects or omissions inconsistent with the rudimentary demands of fair procedure"); Williams v. Taylor, 120 S. Ct. 1495, 1503 (2000) (opinion of Stevens, J.) (noting how "errors that undermine confidence in the fundamental fairness of the state adjudication certainly justify issuance of the federal writ").

In that same vein, Justice Stevens wrote separately in Engle v. Isaac, 456 U.S. 107 (1982), to criticize the majority for dismissing a habeas petition under the procedural default doctrine. See id. at 136-37 (Stevens, J., concurring in part and dissenting in part). Stevens stated that "[a] petition for a writ of habeas corpus should be dismissed if it ... do[es] not describe a violation of any constitutional right." Id. at 136 . Finding no alleged violation of a constitutional right in the respondents' claims regarding the burden of proof for self-defense, Stevens argued that the Court should "simply [have held] that neither of the exhausted claims advanced by respondents justifies a collateral attack on their convictions." Id. at 137.

237. Rose, 455 U.S. at 548 (Stevens, J., dissenting); see also id. ("The doctrine of nonretroactivity, the emerging 'cause and prejudice' doctrine, and today's 'total exhaustion' rule are examples of judicial lawmaking that might well have been avoided by confining the availability of habeas corpus relief to cases that truly involve fundamental unfairness.").

Justice Stevens was also willing to acknowledge that this line between fundamental and nonfundamental rights was a useful one to draw for retroactivity purposes. "In ruling that a constitutional principle is not to be applied retroactively," he reasoned in Rose, "the Court implicitly suggests that the right is not necessary to ensure the integrity of the underlying judgment." Id. at 544 n.8 (Stevens, J., dissenting).

238. See supra text accompanying notes 220-25 (referring to the Warren Court's decisions regarding "fundamental fairness").

239. Smith v. Murray, 477 U.S. 527, 545 (1986) (Stevens, J., dissenting). 
"[f]undamental fairness [as] more than accuracy at trial" and "justice [as] more than guilt or innocence." ${ }^{240}$ In this respect, Justice Stevens's conception of fundamental fairness is broader than the Rehnquist Court's, which, in Justice Stevens's words, would "exalt[] . . accuracy as the only [relevant] characteristic of 'fundamental fairness.", ${ }^{241}$

As this discussion illustrates, something of a consensus has developed among Supreme Court Justices coming from differing perspectives that the federal writ of habeas corpus guards against "fundamental unfairness. ${ }^{242}$ Indeed, the debate over the substantive scope of habeas may be largely understood as a debate over which constitutional claims are necessary to ensure "fundamental fairness." Some assert that a criminal trial cannot be fundamentally "fair" unless all constitutional protections are in force, ${ }^{243}$ while others employ a more stringent definition of "fundamental fairness." ${ }^{244}$ Unfortunately, the term itself is an amorphous and elastic concept, as the decades-long debate over incorporation of the Bill of Rights into the Fourteenth Amendment vividly illustrates. What this discussion also illustrates, however, is that the concept of "fundamental fairness" is quite malleable. Thus, before it can be used as a basis for distinguishing among constitutional claims on habeas, it must be given a more definite content.

\footnotetext{
240. Sawyer v. Whitley, 505 U.S. 333, 361 (1992) (Stevens, J., concurring).

241. Smith, 477 U.S. at 545 (Stevens, J., dissenting).

242. See Teague v. Lane, 489 U.S. 288, 314 (1989) (plurality) (stressing that rules that are "absolute prerequisite[s] to fundamental fairness" should be applied retroactively on habeas); Friedman, Failed Enterprise, supra note 9, at 488 ("Different Justices and decisions identify the purposes of habeas corpus in varying terms .... [b]ut, at bottom, habeas clearly has something to do with [fairness] matters such as vindicating constitutional rights.").

243. Those who take the broader view of "fundamental fairness," however, rarely couch their arguments in those terms. Instead, they advocate different models to argue that all constitutional claims should be cognizable on habeas. See, e.g., Yackle, supra note 75, at 2425-26 (advocating full review of all constitutional claims as part of his view that "[h]abeas is not a backstop against outrageous injustice, but a routine means by which federal claims, both conventional and creative, can be considered in the ordinary course"). But these other models are entirely consistent with the view that the availability of all federal constitutional rights is necessary to assure "fundamental fairness."

244. Advocates of this view generally posit that only a subset of constitutional guarantees serve to secure "fundamental fairness." See, e.g., Friendly, supra note 92, at 156 ("What I do challenge is the assumption that simply because a claim can be characterized as 'constitutional,' it should necessarily constitute a basis for collateral attack when there has been a fair opportunity to litigate it at trial and on appeal."); McCord, supra note 5, at 758 (describing "rights that are fundamental to the fairness of the criminal proceeding" as a possible category of constitutional rights that could be preferred over others in habeas law).
} 
6. In Summary. Of the varying theories that might provide a basis for selecting those constitutional claims that may be relitigated on habeas, the fundamental fairness theory best describes the traditional purpose of federal habeas, while the appellate theory best describes the function of the writ today. Neither would suffice as a selection criteria on its own, however. The fundamental fairness theory, as discussed above, is too vague by itself to provide a basis for distinguishing among various constitutional claims. Likewise, the slight mismatch between appellate practice and habeas renders it inappropriate to adopt blindly the appellate model and to conclude that all federal constitutional claims should be available for relitigation on habeas simply because they all may be litigated on direct appeal. Combining these theories, however, could produce criteria that reflect both the purpose and function of the writ and also could provide a workable basis for picking and choosing among constitutional claims. The next part sketches the contours of this new theory and examines which constitutional claims would be available for relitigation on federal habeas.

\section{A COMBINED THEORY OF HABEAS}

The most logical way to give content and boundaries to the theory of fundamental fairness is to view it through the prism of the appellate theory. In so doing, it is necessary to keep a critical point in mind-that the primary object of this combined theory is to determine which claims may be relitigated after already being heard ( or, presumably, waived) in the state courts. State prisoners who have not had a "full and fair opportunity" to litigate a federal constitutional claim in the state courts would be permitted to raise such a claim on habeas under the combined theory. ${ }^{245}$

245. See supra Part II.B.1. Making habeas available for the litigation of federal constitutional claims not fairly open for review in state court is a function of the combined model itself, not simply a grafting of the "full and fair opportunity" model onto the combined model. If federal habeas is viewed in part as an extension of the state appellate process, habeas should be available, at a minimum, to act as an appeal when the state courts fail to provide one. To do otherwise would be to deny persons with such claims any opportunity to present their federal constitutional claims, which would seem to be fundamentally unfair as well. This goes a long way toward explaining why allowing habeas review in this context has broad-based support, even including scholars such as Professor Bator and Judge Friendly, who would greatly curtail the scope of habeas but who would still hold open the doors of the habeas courts when the states fail to provide an opportunity to litigate constitutional claims. See supra Part II.A.1-2. 
A prisoner would not, however, be permitted to litigate a noncognizable claim again in federal court in what is, in effect, one more appeal, and final resolution of that excluded claim would be entrusted to the state courts. With that in mind, the question then becomes: when would it be fundamentally unfair to foreclose a state prisoner who has already had the opportunity to litigate a federal constitutional claim in the state courts from having what amounts to an additional appeal in federal court on that claim? ${ }^{246}$

The first situation that comes to mind is when the state prisoner has reliable evidence that he is actually innocent of the crime of which he was convicted or that he is "innocent of his sentence"-that is, when he could not rationally have been sentenced to the punishment he received if all the available evidence had been considered. In these situations, it would seem fundamentally unfair to force him to remain in prison without the opportunity to challenge his incarceration. It would also seem fundamentally unfair to permit a state to incarcerate a prisoner-regardless of her guilt-if the procedures by which she was convicted did not satisfy what is considered essential to a fair trial in this country. These very basic procedures include, among a few other things, an unbiased judge, the opportunity for a jury trial, and the provision of counsel. ${ }^{247}$ Both instances of fundamental unfairness are discussed below. ${ }^{248}$

246. This question is, by its very definition, directed toward habeas petitions that attack the underlying criminal conviction or sentence, both of which are appealable through the state courts before reaching federal habeas. Although such claims account for the bulk of the petitions filed by state prisoners under $\S 2254$, this section also reaches other claims of "wrongful" custody, such as the denial of good-time credits or the imposition of disciplinary sanctions in prison, in which the remedy sought is "immediate or speedier release" or the remedy would otherwise "necessarily .... demonstrate[] the invalidity of the .... 'fact or length of confinement." Heck v. Humphrey, 512 U.S. 477, 481-82 (1994) (quoting Preiser v. Rodriguez, 411 U.S. 475,490 (1973)). Because these claims do not involve the underlying judicial judgment of conviction or sentence, it is not clear that leaving state prisoners to their state remedies in this situation (unless those remedies are inadequate) would be fundamentally unfair. At a minimum, these prison-based custody claims involve a different calculus than claims regarding the constitutional infirmity of custody pursuant to conviction. A more detailed analysis of these other types of claims is beyond the scope of this Article.

247. See, e.g., Vasquez v. Hillery, 474 U.S. 254, 266 (1986) (securing the right against discriminatory tampering with the composition of the grand jury); Martin Linen Supply Co. v. United States, 430 U.S. 564, 573 (1977) (concluding that the Constitution protects against directed verdicts for the state in criminal cases); Gideon v. Wainwright, 372 U.S. 335, 344 (1963) (securing the right to counsel for indigents); Tumey v. Ohio, 273 U.S. 510, 531 (1927) (securing the right to an unbiased judge).

248. In discussing which claims would be cognizable on federal habeas, this Article contemplates that federal habeas courts would employ the same constitutional standards on habeas as they do on direct review, except where otherwise noted. Although the Court's recent opinion in 


\section{A. Innocence-Based Claims}

Given the centrality of a person's innocence to the justice of her incarceration, there is a strong argument that it would be fundamentally unfair to deny an innocent person an additional opportunity to establish her innocence in federal court through the writ of habeas corpus. ${ }^{249}$ The Supreme Court has recognized that "innocence" can refer both to innocence of the underlying criminal offense and to innocence of the sentence, at least where the sentence is death. ${ }^{250}$ Indeed, the Court already permits habeas petitioners who can establish either type of innocence the opportunity to proceed on habeas-an opportunity that other petitioners lack. ${ }^{251}$ As noted above, a state prisoner who procedurally defaults on a federal constitutional claim may not raise that claim on federal habeas without first establishing "cause," but a person who is probably innocent of the underlying crime may proceed without demonstrating "cause." 252 State prisoners who are

City of Boerne v. Flores, 521 U.S. 507 (1997), held that Congress may not alter the content of judicial interpretations of the Constitution, see id. at 524, Congress would not appear to run afoul of this prohibition if it exercised its Article III power to define the jurisdiction of the federal courts by granting federal jurisdiction over some, but not all, possible violations of a particular constitutional right. See U.S. CONST. art. III, § 1 ("The judicial Power of the United States, shall be vested in one supreme Court, and in such inferior Courts as the Congress may from time to time ordain and establish." (emphasis added)); id. art. III, § 2, cl. 2 (declaring Congress's control over the Supreme Court's appellate jurisdiction).

249. See Kuhlmann v. Wilson, 477 U.S. 436, 452 (1986) ("[A] prisoner retains a powerful and legitimate interest in obtaining his release from custody if he is innocent of the charge for which he was incarcerated."); Chemerinsky, supra note 5, at 792 ("At a minimum, society should spend additional resources for those with a colorable claim of innocence."); Hoffmann \& Stuntz, supra note 50, at 88 (arguing that "constructing the law of habeas without reference to innocence and guilt means ignoring the central point of the criminal justice system").

250. The Court first recognized the "innocence of the death penalty" claim in Smith $v$. Murray, 477 U.S. 527 (1986). See id. at 537 (acknowledging "that the concept of 'actual,' as distinct from 'legal,' innocence does not translate easily into the context of an alleged error at the sentencing phase of a trial on a capital case," but proceeding to examine the merits of an "innocence of death penalty" claim). The Court subsequently reaffirmed the validity of "innocence of the death penalty" as a means of overcoming procedural bars for defaulted, successive, or abusive claims in Sawyer v. Whitley, 505 U.S. 333, 339-40 (1992), and Schlup v. Delo, 513 U.S. 298, 314-15 (1995).

251. Indeed, one commentator has criticized the Court on this ground: "A showing of actual innocence became the panacea for every ill that might be spoken of the many procedural hurdles erected by the Court's habeas reform efforts." Friedman, Failed Enterprise, supra note 9, at 508.

252. See Murray v. Carrier, 477 U.S. 478, 496 (1986) ("[W]here a constitutional violation has probably resulted in the conviction of one who is actually innocent, a federal habeas court may grant the writ even in the absence of a showing of cause for the procedural default."); supra text accompanying notes 29-32.

The same rule applies to individuals who establish their "innocence of the death penalty," 
able to make the requisite showing of innocence are also permitted in subsequent habeas petitions to litigate claims that they have already litigated, or could have litigated, in prior petitions. ${ }^{253}$ When Congress amended the habeas statutes in 1996, however, it limited the ability of innocent habeas petitioners to overcome these procedural barriers. ${ }^{254}$

There are two primary objections to revisiting innocence-based constitutional claims on federal habeas. First, some have observed that federal review of innocence-related claims is unnecessary because executive clemency already "provide[s] the 'fail safe' in our criminal justice system." ${ }^{255}$ Second, others have expressed hesitation about allowing the federal courts to reexamine the guilt and sentencing determinations on habeas because those determinations are entrusted to the state courts. ${ }^{256}$ Such reexamination, the argument goes, may also be impractical because the passage of time-years, and per-

although the required showing is much more demanding. See supra note 31 . It is not enough to show, as it is with innocence of the underlying crime, that no reasonable jury could have found the defendant guilty. See supra note 31. Instead, the petitioner must show that "but for a constitutional error, no reasonable juror would have found the petitioner eligible for the death penalty under the applicable state law," and the petitioner must make this showing "by clear and convincing evidence." Sawyer, 505 U.S. at 336 (emphasis added).

253. See Sawyer, 505 U.S. at 338-39 (holding that a prisoner may raise a constitutional claim not previously raised in an earlier petition if he meets the "cause and prejudice" standard or is able to demonstrate his innocence of the death penalty); McCleskey v. Zant, 499 U.S. 467, 49496 (1991) (recognizing the same exceptions for individuals able to establish their factual innocence); Kuhlmann v. Wilson, 477 U.S. 436, 454 (1986) (holding that a person may raise a constitutional claim in a "successive" habeas petition if he "supplements his constitutional claim with a colorable showing of factual innocence").

254. Congress appears to have limited the exceptions for innocence to situations where the petitioner is not "guilty of the underlying offense," thereby seemingly removing the exception for innocence of the death penalty. 28 U.S.C. $\$ 2254(\mathrm{e})(2)$. Specifically, this subsection permits development of facts on habeas that were not developed in state courts only when "the facts underlying the claim would be sufficient to establish by clear and convincing evidence that but for constitutional error, no reasonable factfinder would have found the applicant guilty of the underlying offense." Id. (emphasis added); accord id. § 2244(b)(2)(B)(ii) (permitting review of a claim that was not previously raised in an earlier habeas petition because of new facts only if the facts exonerate the petitioner "of the underlying offense"). In addition, Congress seems to have eliminated entirely the ability to raise the same claim again in a subsequent habeas petition, no matter what type of innocence the habeas petitioner might be able to establish. See id. $\S$ 2244(b)(1) ("A claim presented in a second or successive habeas corpus application under $\S$ 2254 that was presented in a prior application shall be dismissed.").

255. Herrera v. Collins, 506 U.S. 390, 415 (1993).

256. See Jackson v. Virginia, 443 U.S. 307, 336 (1979) (Stevens, J., dissenting) (arguing that the federal "sufficiency of the evidence" rule is inappropriate on habeas because "[t]he federal district courts are ... being directed simply to duplicate the reviewing function that is now being performed adequately by state appellate courts"); Friedman, Failed Enterprise, supra note 9, at 544 ("The problem ... is that the state court proceeding is supposedly where society determines guilt."). 
haps decades-between the conviction and sentence and habeas review diminishes the reliability of any federal redetermination. ${ }^{257}$

While not without force, neither of these objections is sufficiently compelling to foreclose to persons who are actually innocent a resort to the federal courts. It is important to understand that the efficacy of executive clemency is questionable. There is no "right" to executive clemency; it is solely a matter of "grace." 258 The Constitution does not require a state to create a clemency mechanism, and it only requires a state to afford "minimal" due process protections at any such hearing. ${ }^{259}$ Not surprisingly, clemency is rarely granted. Since 1973, for example, more than 6100 persons have been sentenced to death in state and federal courts, but only 146 - or $2.4 \%$ - have had their sentences commuted. ${ }^{260}$ Clemency may not, therefore, be a viable fail-safe for erroneous determinations of guilt or sentence. ${ }^{261}$

Permitting federal courts to revisit the question of a state prisoner's innocence is also no more onerous an intrusion into the province of state courts than federal review of other determinations regarding factual questions or mixed questions of constitutional import. Indeed, the purpose of this Article is to minimize the intrusion imposed by federal habeas review itself by limiting the substantive scope of the statutory writ. Where the state prisoner is actually innocent is

257. See Herrera, 506 U.S. at 403 ("Yet there is no guarantee that the guilt or innocence determination [made by a habeas court] would be any more exact. To the contrary, the passage of time only diminishes the reliability of criminal adjudications.").

258. Ohio Adult Parole Auth. v. Woodard, 118 S. Ct. 1244, 1250 (1998) (plurality) (emphasizing that "the heart of executive clemency ... is to grant clemency as a matter of grace").

259. See Herrera, 506 U.S. at 414 ("Of course, although the Constitution vests in the President a pardon power, it does not require the States to enact a clemency mechanism."). The Court addressed the level of procedural protections to be afforded in clemency proceedings in Woodard. In that case, a four-Justice plurality, led by Chief Justice Rehnquist, would attach no constitutionally based procedural guarantees to clemency proceedings, largely because clemency is outside the system for adjudicating guilt or innocence and because "the executive's clemency authority would cease to be a matter of grace ... if it were constrained by ... [constitutionally mandated] procedural requirements." Woodard, 118 S. Ct. at 1252 (plurality). A different four-Justice plurality, led by Justice O'Connor, would recognize that the Due Process Clause provides "some minimal procedural safeguards" in clemency proceedings. Id. at 1254 (O'Connor, J., concurring). Judicial review would still be exceedingly narrow, however. As examples of when review might be appropriate, Justice O'Connor cited "a scheme whereby a state official flipped a coin to determine whether to grant clemency, or . . . a case where the State arbitrarily denied a prisoner any access to its clemency process." Id.

260. See Tracy L. Snell, Bureau of Justice Statistics, Capital Punishment 1997, at 13 (1998).

261. See Friedman, Failed Enterprise, supra note 9, at 506 (arguing that "the opportunity to seek clemency is no substitute for proper judicial procedure"). 
one of the situations in which, under the narrower standard articulated by this Article, habeas review is most warranted. Consequently, the burden of permitting relitigation of innocence-related claims on habeas would be no greater than it currently is, and it would be offset by the other reductions in the substantive scope of habeas. Finally, although the passage of time may make reexamination of innocencebased claims more difficult, that problem is not unique to these types of claims. The difficulties would be diminished, in any event, by the fact that habeas courts would still be required to give some deference to state court factual findings, ${ }^{262}$ and by the fact that habeas petitioners would have a heavy burden to establish the existence of any new facts. ${ }^{263}$ In sum, there is no compelling reason-given its centrality to fundamental fairness-not to acknowledge innocencebased claims on habeas.

Simply acknowledging innocence as a ground for habeas relief is not enough, however, for there are two types of innocence claims, each raising its own concerns and implicating different constitutional rights. A prisoner can argue that he is innocent based entirely on "old" evidence-that is, evidence available at the time of trial or sentencing. Alternatively, a prisoner can contend that the jury might have been correct to convict him on the evidence presented but that newly discovered evidence exonerates him. ${ }^{264}$ Each type of innocence claim is discussed separately.

1. Evidence of Innocence Existing at the Time of Trial or Sentencing. A habeas petitioner can assert her innocence based on evidence available at the time of trial or sentencing in one of two ways. First, she can argue that, based on the evidence actually presented at trial or at the sentencing hearing, no reasonable jury could have convicted her or sentenced her to the punishment imposed. ${ }^{265}$ This due process-based claim for innocence of the underlying offense was recognized by the Supreme Court in Jackson

\footnotetext{
262. See infra Part IV.D.

263. See infra text accompanying notes 282-83.

264. See Bandes, supra note 200, at 503-05 (identifying three types of actual innocence claims: (i) when the evidence at trial is insufficient to establish guilt beyond a reasonable doubt; (ii) when evidence was overlooked and should have been presented at trial, but was not; and (iii) when evidence discovered after trial establishes innocence).

265. See Jackson v. Virginia, 443 U.S. 307, 318 (1979) ("A federal court has a duty to assess the historical facts when it is called upon to apply a constitutional standard to a conviction obtained in a state court.").
} 
v. Virginia. ${ }^{266}$ Because of its strong tie to the petitioner's innocence, habeas petitioners should continue to be permitted to relitigate Jackson claims on habeas under the combined theory proposed in this Article.

Habeas petitioners should also be permitted to challenge the sufficiency of the evidence to support their sentences. Thus far, the innocence exception for sentencing has been limited to sentences of death. ${ }^{267}$ Sentences short of death can be equally unfair, however. Lengthy prison sentences, like death sentences, are often triggered by additional findings made at sentencing. If no reasonable sentencer could have concluded that the evidence supported those findings, continued incarceration is unfair regardless of the length of the sentence. Thus, for both innocence of the crime and innocence of the sentence, a petitioner under the combined theory would prevail by establishing that no rational juror could have convicted her of the underlying crime or sentenced her to the punishment she received based on the evidence presented. ${ }^{268}$

Second, the habeas petitioner would be able to assert that she is innocent in light of evidence that existed at the time of trial or sentencing, but that she did not present. To prevail on this type of claim, the petitioner would have to demonstrate first that she was not responsible for the failure to present the evidence-showing, for example, that the state prosecutor suppressed exculpatory evidence under Brady v. Maryland, ${ }^{269}$ that other state officials interfered with her ability to obtain or present the evidence, ${ }^{270}$ or that her counsel was constitutionally ineffective. ${ }^{271} \mathrm{~A}$ failure properly attributed to the de-

266. See id. at 316 (holding that "no person shall be made to suffer the onus of a criminal conviction except upon sufficient proof-defined as evidence necessary to convince a trier of fact beyond a reasonable doubt of the existence of every element of the offense").

267. See Sawyer v. Whitley, 505 U.S. 333, 335-36 (1992); see also supra text accompanying note 31.

268. This standard mirrors the standard announced in Jackson. See Jackson, 443 U.S. at 319 (identifying "the relevant question" as "whether, after viewing the evidence in the light most favorable to the prosecution, any rational trier of fact could have found the essential elements of the crime beyond a reasonable doubt"). It would, however, depart from the Sawyer standard used to evaluate innocence of the death penalty. See supra note 31.

269. 373 U.S. 83 (1963). The Brady Court held that "the suppression by the prosecution of evidence favorable to an accused upon request violates due process where the evidence is material either to guilt or to punishment." Id. at 87. If the evidence is "material," the defendant is entitled to a new trial.

270. See Brown v. Allen, 344 U.S. 443, 485-86 (1953).

271. See, e.g., Murray v. Carrier, 477 U.S. 478, 488 (1986) ("Ineffective assistance of counsel, then, is cause for a procedural default" because "the Sixth Amendment itself requires that re- 
fendant, however, would not form a basis for revisiting the guilty verdict. The habeas petitioner would also have to demonstrate that no jury evaluating her guilt or her sentence in light of the evidence presented, and the other evidence not presented, could rationally have found her guilty of the offense beyond a reasonable doubt or could have sentenced her to the punishment imposed.

2. Later-Discovered Evidence of Innocence. A habeas petitioner might also contend that new evidence that came to light after his trial and sentencing would exonerate him or would have precluded the trier of fact from imposing the sentence it did. Under the combined theory, a state prisoner in this position would have to overcome two hurdles before being permitted to raise such a claim on federal habeas. As an initial matter, he would have to establish that he exercised due diligence both in finding the evidence and in presenting it promptly to the relevant court's attention. Failure to exercise such diligence would be grounds for barring the claim, unless the failure were attributable to a cause outside the defendant's control. ${ }^{272} \mathrm{~A}$ habeas petitioner would also have to present this newly discovered evidence to the appropriate state tribunal or show that the time for doing so had lapsed, which will more likely be the case. ${ }^{273}$

Unlike the types of innocence-based claims discussed above, a claim premised on newly discovered evidence is more likely to be a bare assertion of factual innocence unaccompanied by any other constitutional violation. ${ }^{274}$ In Herrera $v$. Collins, ${ }^{275}$ a slim majority of the

sponsibility for the default be imputed to the State ...."). Although the standard for evaluating ineffective assistance of counsel claims under Strickland v. Washington, 466 U.S. 668 (1984), has been attacked as insufficiently protective because a prisoner who is clearly guilty will have a much harder, if not impossible, time demonstrating that her counsel's deficient performance "prejudiced" her, see, e.g., Richard Klein, The Emperor Gideon Has No Clothes: The Empty Promise of the Constitutional Right to Effective Assistance of Counsel, 13 HASTINGS CONST. L.Q. 625, 644 (1986), there is no need to revisit Strickland for purposes of raising claims of innocence. That is because state prisoners with colorable proof of innocence would, by definition, be in a better position to establish "prejudice" resulting from their counsels' lack of competence.

272. Although this standard could technically permit a state prisoner to file multiple habeas petitions based on newly discovered evidence, a petitioner would, of course, have to establish why the evidence was not discovered and presented in a prior petition. See infra Part IV.B.

273. See, e.g., Herrera v. Collins, 506 U.S. 390, 410-11 nn.8-10 (1993) (collecting state statutes that limit the time to file a motion for a new trial based on newly discovered evidence).

274. See supra Part III.A.1 (discussing claims involving violations of due process under Jackson v. Virginia, claims of prosecutorial misconduct under Brady, and claims of constitutionally ineffective assistance of counsel under Strickland).

275. 506 U.S. 390 (1993). 
Court held that "[c]laims of actual innocence based on newly discovered evidence have never been held to state a ground for federal habeas relief absent an independent constitutional violation occurring in the underlying state criminal proceeding." ${ }^{276}$ This holding was clouded somewhat by other portions of the majority's opinion and by the separate opinions in the case, however. Notwithstanding its seemingly clear holding, the majority went on to "assume, for the sake of argument in deciding this case, that in a capital case a truly persuasive demonstration of 'actual innocence' made after trial would render the execution of a defendant unconstitutional...." ${ }^{277}$ Fleshing out this argument further, the majority noted that the "threshold showing" under its standard "would necessarily be extraordinarily high." ${ }^{278}$ Two members of that majority, Justices O'Connor and Kennedy, would have reserved the question whether a constitutional basis for such a claim existed. ${ }^{279}$ Justice White concurred separately to opine that such a claim should exist. ${ }^{280}$ Justice Blackmun, joined by two other Justices, dissented on the ground that such a constitutional claim should exist. ${ }^{281}$ Not surprisingly, some academics have read Herrera as recognizing a constitutional foundation for naked claims of innocence. ${ }^{282}$

Because Herrera was based on an interpretation of the statutory writ that Congress is free to amend, the case itself does not pose an impediment to legislative efforts to recognize innocence-based claims as a function of fundamental fairness. Herrera is instructive, however, because the majority sketches the dangers that might flow from a toopermissive standard for judging innocence based on later-discovered evidence-most notably, the potential flood of habeas petitions that

\footnotetext{
276. Id. at 400 .

277. Id. at 417.

278. Id.

279. See id. at 427 (O'Connor, J., concurring) ("[T]he Court has no reason to pass on, and appropriately reserves the question whether federal courts may entertain convincing claims of actual innocence. That difficult question remains open."). But see id. at 419 ("I cannot disagree with the fundamental legal principle that executing the innocent is inconsistent with the Constitution.").

280. See id. at 429 (White, J., concurring) ("In voting to affirm, I assume that a persuasive showing of 'actual innocence' made after trial, even though made after the expiration of the time provided by law for the presentation of newly discovered evidence, would render unconstitutional the execution of the petitioner in this case.").

281. See id. at 430-37 (Blackmun, J., dissenting) (arguing that the execution of the innocent would violate the Eighth and Fourteenth Amendments).

282. See Friedman, Failed Enterprise, supra note 9, at 509 ("What did the Court do [in Herrera]? It actually held, by a vote of $9-0$, that innocent people cannot be executed ....").
} 
would follow if the gates were thrown open to all claims of actual innocence based on later-discovered evidence.

Yet the gates must remain open for the truly legitimate claims of innocence. ${ }^{283}$ Thus, the standard for asserting this type of innocence claim should be difficult, but not practically impossible, to meet. To survive dismissal under the combined theory, a petitioner should be required to present evidence that has some indicia of reliability and that would, if true, create a reasonable doubt in the minds of a jury evaluating that evidence and the evidence also presented at trial or the sentencing hearing. To prevail on the merits, the petitioner would have to prove that there is a reasonable possibility that no rational jury could have convicted her or imposed the sentence it did when presented with all the relevant evidence. For example, a prisoner producing reliable DNA evidence showing that he could not have been the perpetrator of the crime of which he was convicted would be entitled to a hearing and perhaps relief, unless the purportedly exculpatory DNA evidence was not inconsistent with the prosecution's theory of the case. ${ }^{284}$ Admittedly, these standards are high, but they would leave habeas open to the truly innocent, whose continued incarceration would be fundamentally unfair.

Thus, in the name of establishing her innocence, a habeas petitioner should be permitted to relitigate constitutional claims arising under Jackson v. Virginia and its analogue for innocence of the sentence, claims of unconstitutional state action or ineffective assistance of counsel related to her inability to present exculpatory evidence at trial or sentencing, and Herrera-type innocence claims premised on evidence first discovered after conviction or sentencing.

283. Senator Leahy recently introduced a bill that seeks to hold open post-conviction relief based on exonerative DNA evidence. See Innocence Protection Act of 2000, S. 2073, 106th Cong.

284. Cases of actual innocence are not common, but they do occur. See, e.g., STAFF OF House Subcomm. on Civil and Constitutional Rights of the Comm. ON THE Judiciary, 103d Cong., InNOCEnCE AND the Death Penalty: Assessing the Danger of Mistaken EXECUTIONS 3 (Comm. Print 1994) (reporting that in the past 20 years, 47 death row inmates were released and subsequently had charges against them dropped, or they were acquitted or pardoned); Stefanie Lindeman, Note, Because Death Is Different: Legal and Moral Arguments for Broadening Defendants' Rights to Discovery in Federal Capital Cases, 73 ST. JOHN's L. REV. 541, 550 (1999) (stressing that "in the last 20 years at least 70 people in the United States have been released from death rows after being found innocent"). The incidence of these cases is only likely to increase as DNA evidence becomes more widely available. 


\section{B. Procedures Essential to Fairness of the Criminal Process}

The innocence-based claims discussed above do not constitute the entire universe of constitutional claims that habeas petitioners may revisit on collateral attack under a writ fashioned on a combination of the fundamental fairness and appellate theories. As both the text of the Constitution and Supreme Court precedent make clear, the concept of fundamental fairness guards against more than the incarceration of innocent persons. The Bill of Rights establishes several procedural guarantees that apply to all persons accused of crimes, whether they be guilty or innocent. ${ }^{285}$ The Court has reaffirmed this notion-that the Constitution protects procedural regularity for its own sake-by acknowledging a category of constitutional errors that warrant automatic reversal, even if their commission did not affect the outcome of the trial proceedings. ${ }^{286}$ Moreover, at least one of the "watershed rules of criminal procedure" that are to be given retroactive effect under Teague-namely, claims that the proceeding was "dominated by mob violence"-appears to be concerned with procedural regularity. ${ }^{287}$ Thus, there is good reason to think that it would be fundamentally unfair not to extend an additional federal "appeal" via habeas, even to those without an adequate claim of actual innocence, if the state proceedings by which such persons were convicted did not provide the essential components of criminal process that society considers vital to a just adjudication of guilt. ${ }^{28}$

Identifying the rudimentary components of a just criminal proceeding is no easy task. At a minimum, such a basic right must be secured by the Constitution and be made applicable to the states through the Due Process Clause of the Fourteenth Amendment, which assures that the right is "a 'principle of justice so rooted in the traditions and conscience of our people as to be ranked as fundamen-

285. See Kimmelman v. Morrison, 477 U.S. 365, 380 (1986) (emphasizing that "[t]he constitutional rights of criminal defendants are granted to the innocent and the guilty alike").

286. See supra text accompanying notes 62-67 (listing "structural errors").

287. See Teague v. Lane, 489 U.S. 288, 313 (1989) (plurality) (reasoning that "procedures... central to an accurate determination of innocence or guilt" include assurances that "the proceeding was [not] dominated by mob violence; that the prosecutor [did not] knowingly [make] use of perjured testimony; or that the conviction was [not] based on a confession extorted from the defendant by brutal methods").

288. Indeed, Justice Scalia, while advocating a version of the "full and fair opportunity" approach, nevertheless recognized that it would be appropriate for a federal habeas court to revisit the merits of a claim "go[ing] to the fairness of the trial process or to the accuracy of the ultimate result." Withrow v. Williams, 507 U.S. 680, 720 (1993) (Scalia, J., concurring in part and dissenting in part). 
tal." ${ }^{289}$ But simple incorporation of a constitutional right that secures a particular procedural component is not sufficient under the combined theory to place that component among the truly essential. Incorporation alone establishes that a constitutional right is important enough to be made binding on the states during trial. The question here, however, is not whether the rights should be enforced against the states. Instead, the issue is whether a state prisoner should have one more chance to relitigate alleged violations of those rights in federal court after already having the opportunity to do so before the state tribunals. ${ }^{290}$ There is no logical incongruity in concluding that, although all incorporated rights are important enough to apply in state proceedings, only some of them are important enough to warrant an additional appeal in federal court.

That said, the Supreme Court has regrettably not yet formulated any single test for distinguishing among those incorporated constitutional rights that are critical to fundamental fairness and those that are not. In determining which constitutional errors are "structural" and therefore subject to automatic reversal regardless of prejudice-a potential proxy for the fundamentality of a right-the Court has employed several different criteria over the years. In most cases, the Court has looked to practical considerations in assessing whether an error was structural and has found errors to be structural where there was no workable way to assess harmlessness under the harmless error test. ${ }^{291}$ In many of those same cases, the Court also looked to whether the error, as a matter of policy, was sufficiently important to the workings of trials in our country to be deemed "structural." 292 The Court has not purported to adhere to any single test, however, and it

289. Palko v. Connecticut, 302 U.S. 319, 325 (1937) (quoting Snyder v. Massachusetts, 291 U.S. 97, 105 (1934)).

290. See supra text accompanying note 146.

291. See supra note 144. As that footnote observes, the Court almost always cited the impracticality of harmless error review as a reason for declaring a certain violation "structural error." With respect to many of these "structural errors," there is no reason to question the Court's conclusions. See, e.g., Sullivan v. Louisiana, 508 U.S. 275, 280 (1993) (recognizing that the harmless error test is meaningless when the jury does not receive an adequate reasonable doubt instruction because there is "no object, so to speak, upon which harmless-error scrutiny can operate"); McKaskle v. Wiggins, 465 U.S. 168, 177-78 n.8 (1984) (concluding that the harmless error test is meaningless when a defendant is wrongly denied the right to represent herself because self-representation often undercuts the effectiveness of the defense).

292. See, e.g., Sullivan, 508 U.S. at 281 (noting that the right to a jury trial was a "basic protection" (citation and internal quotations omitted)); Vasquez v. Hillery, 474 U.S. 254, 264 (1986) (holding that discrimination in the selection of grand jurors mandated automatic reversal due to "[t]he overriding imperative to eliminate this systemic flaw in the charging process"). 
has never attempted to define why the policy behind a particular right has justified its inclusion in the small class of "structural errors."

The Court's retroactivity jurisprudence is equally unhelpful as a basis for determining which incorporated rights secure "fundamental fairness." Although the Teague plurality created an exception to the general rule against retroactive application of "new rules" for "watershed rules of criminal procedure,",933 the Court frankly admitted that it was "unlikely that many such components of basic due process have yet to emerge."294 The Court's subsequent cases bear this prediction out, as the Court has rejected every attempt to fit new rules into this exception. ${ }^{295}$ As a result, the Court has developed the contours of this exception solely by negative inference. This exception is not ideal as a proxy for the importance of a constitutional right in any event because it focuses on accuracy-based rights, a focus that is too narrow for the fundamental fairness/appellate theory. ${ }^{296}$

Because the Court's other habeas jurisprudence does not readily enumerate which constitutional rights secure the components of a criminal trial that society considers essential to a just adjudication of guilt, there is a need for a systematic examination of this question, which this Article attempts to set forth. Fortunately, the Court's precedent does provide some helpful guidance regarding the relative importance of the different incorporated constitutional rights. What follows is a brief sketch of the constitutional rights likely to be deemed critical enough to the fairness of state procedures to warrant an opportunity for relitigation of claimed violations on habeas.

1. Claims of Constitutional Violation That May Be Relitigated on Habeas. The constitutional rights essential to making criminal trials fair today, and which are important enough to permit habeas petitioners to raise them again after litigation in the state courts, would seem to include the following:

a. The Fourteenth Amendment right to an orderly trial by an unbiased judge and jury. This small cluster of rights is listed first be-

293. Teague v. Lane, 489 U.S. 288, 311 (1989) (plurality).

294. Id. at 313.

295. See supra note 126 (collecting cases in which the Court has rejected a habeas petitioner's attempt to fit a "new rule" into Teague's second exception).

296. See supra text accompanying notes 240-41 (discussing Justice Stevens's conception of fundamental fairness). 
cause procedural regularity is a hallmark of criminal adjudication under the Constitution. It is for this reason that the Court has not hesitated to overturn convictions when the trial was dominated by mob violence, ${ }^{297}$ when the judge's impartiality was compromised by a personal incentive to convict, ${ }^{298}$ or where the jury's impartiality was in question or its composition was tampered with. ${ }^{299}$ A defendant tried when any of these conditions exists is not receiving what most Americans would agree is a real trial, let alone a fair one.

b. The Sixth and Fourteenth Amendment right to a jury verdict. It is a fundamental tenet of the American criminal justice system that a person is presumed innocent until a jury concludes that the state has established his guilt beyond a reasonable doubt. As a result, a habeas petitioner should be able to revisit, through a collateral attack, claims that the trial judge dispensed with the jury without a proper waiver of the right to a jury trial and directed a verdict for the state, ${ }^{300}$ or that the jury received a constitutionally deficient reasonable doubt instruction. ${ }^{301}$ There is currently some disagreement among the Justices regarding the status of other errors in jury instructions, particularly where the error arguably interfered with the jury's ability to ascertain whether an element had been established. ${ }^{302}$ There is a

297. See Moore v. Dempsey, 261 U.S. 86, 90-91 (1923) (“[I]f in fact a trial is dominated by a mob so that there is an actual interference with the course of justice, there is a departure from due process of law." (citing Frank v. Mangum, 237 U.S. 309, 335 (1915))).

298. See Tumey v. Ohio, 273 U.S. 510, 523 (1927) ("But it certainly violates the Fourteenth Amendment to subject [a defendant's] liberty or property to the judgment of a court the judge of which has a direct, personal, substantial, pecuniary interest in reaching a conclusion against his case.").

299. See Gray v. Mississippi, 481 U.S. 648, 668 (1987) (upholding a death penalty verdict where the trial judge excluded a clearly qualified juror during voir dire and holding that a viol ation of the right to an impartial jury is per se reversible). Tampering with jury composition would encompass both claims of discrimination in the selection of grand jurors, see, e.g., Vasquez v. Hillery, 474 U.S. 254, 266 (1985) (holding that discrimination among members of the grand jury is "structural error"), and discrimination in the selection of petit jurors, see Batson v. Kentucky, 476 U.S. 79, 86 (1986) (holding that racial discrimination in the selection of petit jurors violates the Equal Protection Clause).

300. See United States v. Martin Linen Supply Co., 430 U.S. 564, 572-73 (1977) (“[A] trial judge is prohibited from entering a judgment of conviction or directing the jury to come forward with such a verdict [for the state].”).

301. See Sullivan v. Louisiana, 508 U.S. 275, 281 (1993) (holding that a constitutionally deficient reasonable doubt instruction requires reversal of a conviction).

302. The Court is currently divided over how to handle errors in jury instructions where the omission or misdescription of the element precludes the jury from making a finding on that element. When it is possible for a reviewing court to conclude that the jury necessarily and actually found the missing element when it found the other elements, there is no need for reversal. 
compelling argument that errors that precluded or prevented the jury from finding an element effectively direct a verdict for the state on that element and accordingly warrant automatic reversal. This sort of instructional error would therefore seem to have the strongest basis for relitigation on habeas. Instructional errors that do not take away from the jury's ability to find an element, however, would not seem to warrant an additional "appeal" via habeas.

c. The Sixth Amendment right to a public trial. Inquisitorial trials behind closed doors are anathema to our system of criminal justice and are barred by the Sixth Amendment's guarantee of the right to a public trial. Violation of this right is also a structural error. ${ }^{303}$ Accordingly, claims premised on this right should be reheard on habeas.

d. The Sixth Amendment right to counsel: deprivation of counsel. Since Gideon v. Wainwright, ${ }^{304}$ the Court has consistently held that the failure to provide counsel to defendants tried for felonies and certain misdemeanors is a "structural error" warranting automatic reversal. ${ }^{305}$ The right to counsel has been held to guarantee the presence of counsel at all "critical stages" of the criminal process-from the initial appearance through sentencing. ${ }^{306}$ Given the

See Carella v. California, 491 U.S. 263, 271 (1989) (Scalia, J., concurring). When it is not possible to so conclude, Justice Scalia would find that the conviction must be reversed because not every element has been found by a jury beyond a reasonable doubt. See California v. Roy, 519 U.S. 2, 7-8 (1996) (Scalia, J., concurring). Other members of the Court would uphold the verdict as long as the error is harmless, presumably because no rational jury could have failed to find the missing element. See Neder v. United States, 119 S. Ct. 1827, 1838 (1999) (opinion of Rehnquist, C.J., and O'Connor, Kennedy, Thomas, \& Breyer, JJ.); Rose v. Clark, 478 U.S. 570, 582 \& n.11 (1986) (opinion of Burger, C.J, and White, Rehnquist, \& O'Connor, JJ.).

303. See Waller v. Georgia, 467 U.S. 39, 49 n.9 (1984) (holding that closing a trial to all persons other than witnesses, court personnel, the parties, and the lawyers violates the Sixth Amendment's guarantee of a public trial).

304. 372 U.S. 335 (1963).

305. See, e.g., Arizona v. Fulminante, 499 U.S. 279, 309 (1991) (declaring a violation of Gideon to be a "structural defect[] in the constitution of the trial mechanism, which def[ies] analysis by 'harmless-error' standards"); Chapman v. California, 386 U.S. 18, 23 \& n.8 (1968) (listing Gideon and its assurance of the right to counsel as one of the "constitutional rights so basic to a fair trial that their infraction can never be treated as harmless error").

306. See, e.g., Coleman v. Alabama, 399 U.S. 1, 9-10 (1970) (stating that a preliminary hearing, where a judge determines whether there is probable cause to detain a defendant for trial, is a "critical stage" requiring counsel); Mempa v. Rhay, 389 U.S. 128, 137 (1967) (establishing that a sentencing proceeding is a "critical stage" where an attorney must be afforded); White v. Maryland, 373 U.S. 59, 60 (1963) (ruling that the initial appearance before a court, where a defendant is informed of his rights, is a "critical stage" at which counsel is required, the violation 
complexities of the criminal law, having counsel present at these "critical stages" would seem to be one of the essential components that make the American adversarial criminal process what it is.

The right to the presence of counsel is not limited to these situations, however. In a troika of cases, the Supreme Court held that counsel was also required to be present at post-indictment line-ups of suspects, at one-man "show-ups," and at preliminary hearings where a witness is present to identify the defendant as the perpetrator of a crime. ${ }^{307}$ In these situations, counsel is not acting as an advocate, as she is during the "critical stages" discussed above. Instead, counsel is essentially functioning as a witness to ensure the fairness of the identification procedure. The Supreme Court itself has recognized this distinction, as the absence of counsel from these identification procedures results in the exclusion of the identification evidence, rather than in an inquiry into whether the absence prejudiced the defendant in the proceedings as a whole, which is the usual test when counsel is absent. ${ }^{308}$ The same may be said of Sixth Amendment claims arising under Massiah v. United States, ${ }^{309}$ which requires the exclusion of any confession deliberately elicited by police from a defendant after he has retained counsel. ${ }^{310}$ These latter types of counsel claims are less compelling, and they may therefore not warrant relitigation on habeas, particularly if alternative means of ensuring the fairness of the identification procedures or police questioning are developed. ${ }^{311}$

of which is reversible error if the defendant is required to make any binding statements); Hamilton v. Alabama, 368 U.S. 52, 54 (1961) (holding that an arraignment, where a defendant enters a plea, is a "critical stage" and the absence of counsel is per se reversible if the plea is binding). There is also a right to counsel on the first appeal of right, but that right is grounded in the Due Process Clause (rather than in the Sixth Amendment). See Douglas v. California, 372 U.S. 353, 355 (1963).

307. See Gilbert v. California, 388 U.S. 263, 273 (1967) (creating an exclusionary rule for incourt identifications based on prior identifications where counsel was not present); United States v. Wade, 388 U.S. 218, 228 (1967) (establishing the right to counsel at pretrial, postindictment line-ups and one-man show-ups); see also Moore v. Illinois, 434 U.S. 220, 227-31 (1977) (applying Wade and Gilbert to a witness identification occurring during a preliminary hearing). The Due Process Clause also provides some protection against suggestive identification procedures. See Stovall v. Denno, 388 U.S. 293, 301-02 (1967).

308. Compare supra note 38, with Gilbert, 388 U.S. at 273 (establishing the exclusionary rule for evidence obtained in violation of the right to counsel).

309. 377 U.S. 201 (1964).

310. See id. at 206; $c f$. United States v. Henry, 447 U.S. 264, 273 (1980) (noting that voluntary statements to a known police informant were not "deliberately elicited" and could be admitted at trial).

311. For example, computers might be used to electronically store the photos presented in a photographic line-up or to digitally record in-person line-ups. 
e. The Sixth Amendment right to counsel: the right to represent oneself. The Court has also recognized that criminal defendants have a right to represent themselves in criminal trials if they are competent to make that choice. ${ }^{312}$ Recognizing how basic it is to our system of justice to permit a defendant to disclaim the counsel the state assigns in favor of representing himself, the Court has held that the failure to grant a competent person's wish to represent himself is grounds for automatic reversal. ${ }^{313}$ Although this type of claim is unlikely to arise often, it should nevertheless be available on habeas.

f. The Sixth Amendment right to competent counsel. As the Supreme Court has noted several times, the right to counsel is meaningless unless counsel is minimally competent. ${ }^{314}$ In developing a definition for competence in Strickland $v$. Washington, ${ }^{315}$ the Supreme Court started from the premise that " $[\mathrm{t}]$ he benchmark for judging any claim of ineffectiveness must be whether counsel's conduct so undermined the proper functioning of the adversarial process that the trial cannot be relied on as having produced a just result." ${ }^{316}$ Not surprisingly, the Court ultimately selected a standard that requires defendants to establish not only that their counsel's performance "fell below an objective standard of reasonableness," but also that "there is a reasonable probability that, but for counsel's unprofessional errors, the result of the proceeding would have been different." ${ }^{317}$

By including a "prejudice" element in the prima facie showing that a defendant must make to prevail on a claim of ineffective assistance of counsel, Strickland means that clearly guilty persons are less likely to prevail on their claims because they will have more difficulty establishing prejudice. Under the Court's current interpretation of this constitutional right, lower courts have found this to be the case even when counsel is asleep during the trial. ${ }^{318}$ In these situations,

\footnotetext{
312. See Faretta v. California, 422 U.S. 806, 836 (1975).

313. See McKaskle v. Wiggins, 465 U.S. 168, 177 n.8 (1984).

314. See Strickland v. Washington, 466 U.S. 668, 687 (1984) (“[T]he proper standard for attorney performance is that of reasonably effective assistance.”); McMann v. Richardson, 397 U.S. 759, $771 \mathrm{n} .14$ (1970) ("[T]he right to counsel is the right to the effective assistance of counsel.").

315. 466 U.S. 668 (1984).

316. Id. at 686.

317. Id. at 688,694 .

318. See, e.g., McFarland v. State, 928 S.W.2d 482, 505 (Tex. Crim. App. 1996) (rejecting an "ineffective assistance of counsel" claim when one of petitioner's two trial attorneys slept through the trial), cert. denied, 519 U.S. 1119 (1997); Ex parte Burdine, 901 S.W.2d 456, 456-58
} 
counsel is, for all intents and purposes, absent from the trial. Denying relief in these situations would appear to be inconsistent with Gideon, however, because Gideon dictates automatic reversal of a conviction obtained when counsel is physically absent. ${ }^{319}$ There is no logical reason why functional absence of counsel should be treated differently from physical absence. Thus, claims of ineffective assistance of counsel premised on "functional absence" should clearly be available for relitigation on habeas, just as claims arising under Gideon are. ${ }^{320}$

The argument for relitigating claims of ineffective assistance of counsel that do not involve "functional absence" is somewhat less compelling. Claims of ineffective assistance of counsel are commonplace. They account for $25 \%$ of all constitutional claims raised in habeas petitions filed by state prisoners, ${ }^{321}$ and they are usually without merit, as many petitioners try to recast dissatisfaction with the outcome as dissatisfaction with their attorney. The "reasonable competence" standard currently employed allows many of these less meritorious claims to go forward, but there is little reason to suspect that a trial in which the quality of counsel's representation lapsed on one or two instances is fundamentally unfair or that it merits relitigation on federal habeas after a full opportunity for litigation in state court. Claims of ineffectiveness that fall short of "functional absence" but nevertheless affect the entire course of representation should, however, be available for relitigation on habeas. ${ }^{322}$ Congress may wish to distinguish between the varying types of Sixth Amendment claims

(Tex. Crim. App.) (Maloney, J., dissenting from denial of application for writ of habeas corpus) (criticizing the majority for upholding a conviction obtained when the petitioner's counsel slept through part of his trial), cert. denied sub nom. Burdine v. Texas, 515 U.S. 1107 (1995). But see Tippins v. Walker, 77 F.3d 682, 687 (2d Cir. 1996) (concluding that representation was ineffective if "counsel was repeatedly unconscious at trial for periods of time in which defendant's interests were at stake"); Javor v. United States, 724 F.2d 831, 833 (9th Cir. 1984) ("[W]hen an attorney for a criminal defendant sleeps through a substantial portion of the trial, such conduct is inherently prejudicial and thus no separate showing of prejudice is nece ssary.").

319. See supra note 62 and accompanying text.

320. There is a good argument that claims of "functional absence" should also be exempted from the requirement that a defendant establish prejudice under Strickland, in order to bring them into line with Gideon-based claims of physical absence. A more detailed discussion of this point is beyond the scope of this Article, however.

321. See HANSON \& DALEY, supra note 21, at 14.

322. Accord Williams v. Taylor, 120 S. Ct. 1495, 1503-04 (2000) (opinion of Stevens, J.) (listing "[t]he deprivation of the right to effective assistance of counsel recognized in Strickland" as an error "that undermine[s] confidence in the fundamental fairness of the state adjudication"). 
and to permit only the more serious type to be raised on federal habeas.

g. The Sixth Amendment right to confront witnesses. The Confrontation Clause encompasses two distinct, but intimately related, rights. The first is the right of compulsory process, which enables a criminal defendant to call his accusers before him and prevents the state from secreting away exculpatory testimony. Included within its scope is the right to obtain the assistance of the prosecution in identifying witnesses and the aid of the court in forcing those witnesses to testify. ${ }^{323}$ These rights are important components of fair trial procedure, and they should remain available for relitigation on habeas.

Once these witnesses are before the court, the Confrontation Clause also safeguards the ability of a defendant to cross-examine those witnesses or to ensure that their absent testimony is properly admitted. States may not completely preclude all cross-examination, ${ }^{324}$ and they must insist that evidence introduced from absent witnesses through the state's hearsay rule have sufficient "indicia of reliability." ${ }^{325}$ In many respects, these rights simply imbue state evidentiary rules with constitutional significance. ${ }^{326}$ In the absence of a situation where there is a dramatic departure from these state rules, litigation over compliance with these rules can be left to the state courts, which are more familiar with their own procedural rules.

323. See Washington v. Texas, 388 U.S. 14, 23 (1967) (holding that the trial court must compel testimony of recalcitrant witnesses for the accused); Roviaro v. United States, 353 U.S. 53, 62-63 (1957) (mandating that the prosecution must help a defendant identify witnesses when such witnesses' testimony is "highly relevant").

324. See Davis v. Alaska, 415 U.S. 308, 318 (1974).

325. Ohio v. Roberts, 448 U.S. 56, 65 (1980).

326. See, e.g., John G. Douglass, Beyond Admissibility: Real Confrontation, Virtual CrossExamination, and the Right to Confront Hearsay, 67 GEO. WASH. L. REV. 191, 195 (1999) ("By treating the Confrontation Clause as a rule that excludes unreliable hearsay, the Court has doomed the rule to redundancy with the law of evidence in the great majority of cases."); Richard D. Friedman, Confrontation: The Search for Basic Principles, 86 GEO. L.J. 1011, 1022 (1998) ("[T] he Supreme Court has tended to conform the Confrontation Clause to prevailing hearsay doctrine. This approach devalues the Confrontation Clause, treating it as a constitutionalization of an amorphous and mystifying evidentiary doctrine ...."); Edye U. Moran, Pyrrhic Victories and Permutations: New Developments in the Sixth Amendment, Discovery, and Mental Responsibility, ARMY LAW., Apr. 1998, at 106 ("This year, as in years past, the Confrontation Clause in child sex abuse cases transmogrifies what are normally simple hearsay evidentiary issues into weighty Constitutional arguments."). 
h. The Fifth Amendment privilege against self-incrimination. It would offend most reasonable persons if the state were permitted to introduce evidence obtained by beating a confession out of a person. ${ }^{327}$ Obviously, reasonable people understand that innocent suspects might confess to crimes they did not commit as a result of abuse, torture, or fear of death. Accordingly, instances of physical coercion, and perhaps some extreme cases of psychological coercion, should be redressible on habeas. Until its decision in Arizona v. Fulminante, ${ }^{328}$ the Court had regarded involuntary confessions as grounds for automatic reversal; now they are evaluated for harmfulness. ${ }^{329}$ This recent change in course, however, does not alter the fundamental importance of this guarantee.

i. The Fifth Amendment guarantee against double jeopardy. The Double Jeopardy Clause protects against multiple prosecutions for the same crime and multiple punishments for the same crime. ${ }^{330}$ It is designed to preclude the state from wearing down an individual with repeated prosecutions (if he is initially acquitted) or repeated punishments (if he is initially found guilty). This is accordingly a fundamental protection against oppressive government action that warrants relitigation on habeas.

j. The Fifth Amendment protection against cruel and unusual punishment. Since the Court's tripartite decisions in Gregg $v$. Georgia, ${ }^{331}$ Jurek v. Texas, ${ }^{332}$ and Woodson v. North Carolina, ${ }^{333}$ holding that the death penalty could be constitutionally imposed

327. See, e.g., Teague v. Lane, 489 U.S. 288, 313 (1989) (plurality) (noting that one "component[] of basic due process" that invokes a "classic ground[]" for issuing a writ is a claim "that the conviction was based on a confession extorted from the defendant by brutal methods" (citations and internal quotations omitted)); Brown v. Mississippi, 297 U.S. 278, 286 (1936) (overturning on direct appeal a conviction based on a confession extracted by physical brutality).

328. 499 U.S. 279 (1991).

329. Compare id. at 312 (holding that the introduction into evidence of involuntary confessions should be judged by the harmless error standard), with Payne v. Arkansas, 356 U.S. 560, 568 (1958) (holding that the introduction into evidence of involuntary confessions warrants automatic reversal of the conviction).

330. See Ex parte Lange, 85 U.S. (18 Wall.) 163, 173 (1873) (“[W]e do not doubt that the Constitution was designed as much to prevent the criminal from being twice punished for the same offense as from being twice tried for it."). This right was incorporated and made applicable to the states in Benton v. Maryland, 395 U.S. 784, 787 (1969).

331. 428 U.S. 153 (1976).

332. 428 U.S. $262(1976)$

333. 428 U.S. 280 (1976). 
under certain circumstances, the Court has articulated an elaborate set of procedures that states must follow in sentencing persons to death.

Although violation of these procedures has not typically been subject to automatic reversal as "structural error," and although these procedures are of recent vintage, ${ }^{334}$ the grave consequences for error and the importance of these procedures to assuring a just and rational sentence make these types of claims appropriate for relitigation on federal habeas. ${ }^{335}$

$k$. The Fourteenth Amendment's Due Process Clause. As the Court's incorporation jurisprudence shows, the concept of due process has been interpreted to cover several different types of misconduct by the state-everything from impermissible comments by prosecutors $^{336}$ to domination of a trial by a mob. Owing to this elasticity, it is difficult to say whether any particular due process claim should be relitigated on habeas. Instead, these claims should be judged individually to see whether they implicate rights-similar to the ones mentioned above-that are critical to what society deems necessary for a trial to be fair.

2. Claims of Constitutional Violation That May Not Be Relitigated on Habeas. For the reasons discussed above, not every violation of an incorporated constitutional right warrants an additional "appeal" to a federal court. The constitutional claims not listed above

334. State capital sentencing procedures must adhere to two guiding principles. First, the procedures must ensure that the process of determining which defendants are eligible for the death penalty channels the decisionmaker's discretion in a regulated and rational manner. Before a person may be sentenced to death, he must be convicted of a crime for which the death penalty is an appropriate punishment, and the jury must find at least one "aggravating circumstance" that makes the death penalty particularly appropriate, that narrows the class of persons eligible for the death penalty, and that is not vague. See Tuilaepa v. California, 512 U.S. 967, 971-72 (1994). Second, the sentencing body—when determining which eligible defendants will actually receive the death penalty—must be permitted to make an individualized determination based on the defendant's character and the circumstances of the crime. See id. at 972-73. This two-part system has not been universally embraced. See Walton v. Arizona, 497 U.S. 639, 664 (1990) (Scalia, J., dissenting) (decrying these two principles as irreconcilable).

335. See, e.g., Harris v. Alabama, 513 U.S. 504, 516 (1995) ("Our opinions have repeatedly emphasized that death is a fundamentally different kind of penalty from any other that society may impose." (citations omitted)).

336. See, e.g., Griffin v. California, 380 U.S. 609, 614-15 (1965) (ruling that a prosecutor may not comment on a defendant's invocation of his constitutional right not to testify on his own behalf). 
should normally be entrusted to the states to correct, as long as the state provides a petitioner an opportunity to litigate them. A small sampling of the claims that would no longer be cognizable if statutory habeas were amended to reflect the combined approach includes the following:

a. Fourth Amendment claims. Claims regarding the Fourth Amendment's exclusionary rule should not be cognizable on habeas. As the Court noted in Stone v. Powell, ${ }^{337}$ a violation of the Fourth Amendment by the police can be adequately addressed at trial or on direct appeal, when the sting of a reversal is most likely to deter future unconstitutional behavior by police. ${ }^{338}$ Because Fourth Amendment violations also do not taint the trial itself, they are not sufficiently central to the procedural regularity of the adjudication of guilt or innocence to warrant additional review on habeas.

b. Fifth Amendment Miranda claims. Similarly, claims that the police failed to provide Miranda warnings do not necessarily mean that the resulting confession was involuntary. ${ }^{339}$ In that respect, Miranda's exclusionary rule is broader than the Fourth Amendment's, which at least confines suppression to cases where there has been a violation of the Constitution. ${ }^{340}$ Thus, while the admission of involuntary confessions ranks among the more fundamental of the constitutional violations, technical violations of Miranda do not, and accordingly should not be reheard on habeas.

c. The Sixth Amendment right to a speedy trial. This constitutional guarantee is designed to assure that the threat of

\footnotetext{
337. 428 U.S. 465 (1976).

338. See id. at 493 ("There is no reason to believe, however, that the overall educative effect of the exclusionary rule would be appreciably diminished if search-and-seizure claims could not be raised in federal habeas corpus review of state convictions.").

339. The Court has repeatedly observed that non-Mirandized statements may be voluntary and therefore constitutionally admissible under the Fifth Amendment. See, e.g., Oregon v. Elstad, 470 U.S. 298, 306-07 (1985) ("The Miranda exclusionary rule ... sweeps more broadly than the Fifth Amendment itself. It may be triggered even in the absence of a Fifth Amendment violation.”); Michigan v. Tucker, 417 U.S. 433, 449-50 (1974) (exempting voluntarily given, nonMirandized statements from the "fruit of the poisonous tree" doctrine, because not all Miranda violations entail constitutional violations); Harris v. New York, 401 U.S. 222, 225-26 (1971) (ruling that voluntarily non-Mirandized statements, unlike involuntary statements obtained in violation of the Fifth Amendment, may be admitted for impeachment purposes).
}

340. See supra note 189 and accompanying text. 
prosecution and/or pretrial detainment does not linger for an inordinate amount of time. ${ }^{341}$ While this right is important, someone who has been indicted but not tried has other pretrial remedies, including the related statutory habeas writ, 28 U.S.C. $§ 2241$, available to him that should be sufficient in all but the most egregious cases. ${ }^{342}$

d. Sixth Amendment instructional errors. As discussed above, errors in jury instructions that do not preclude or prevent the trier of fact from finding an element of a crime should not be cognizable on habeas. ${ }^{343}$

e. The Sixth Amendment right to the presence of counsel at identification proceedings. For the reasons mentioned above, claims that counsel was not present at pretrial events designed to enable witnesses to identify the defendant as the perpetrator of a crime may not be subject to relitigation on habeas, especially if there is an alternative means of assuring the fairness of the identification procedure. Massiah claims may also be precluded, for many of the same reasons. ${ }^{344}$

f. The Sixth Amendment right to competent counsel. Congress may also wish to distinguish among claims falling within the current definition of ineffective assistance of counsel and to foreclose relitigation of claims not premised on "functional absence" of counsel and other claims of ineffectiveness affecting the entire course of representation. ${ }^{345}$

g. The Sixth Amendment right of cross-examination. As noted above, claims premised on minor departures from state evidentiary rules governing the admissibility of hearsay evidence and the scope of cross-examination may not warrant relitigation on habeas. ${ }^{346}$

341. See Barker v. Wingo, 407 U.S. 514, 519-21 (1972) (detailing the rationale behind the right to a speedy trial).

342. See 28 U.S.C. $\$ 2241$ (1994) (giving federal judges the power to grant the writ of habeas corpus for prisoners in custody, but not necessarily pursuant to a conviction).

343. See supra text accompanying notes 300-02.

344. See supra text accompanying notes 309-11.

345. See supra text accompanying note 321.

346. See supra text accompanying notes 324-26. 
h. Fourteenth Amendment due process claims. As mentioned above, there may be some due process claims that do not protect essential components of fairness during the criminal process. Those rights would not be cognizable on habeas under the combined model.

\section{In Summary}

Adopting a combined theory of habeas corpus that uses the appellate model to give content to the concept of fundamental fairness, this Article has attempted to articulate the criteria for determining which constitutional claims should remain open for relitigation on habeas and which may only be litigated in the state courts. This part also briefly discussed the constitutional claims that would satisfy these criteria. The following table sets forth the results of this analysis: 


\begin{tabular}{|c|c|}
\hline $\begin{array}{l}\text { Claims Cognizable on } \\
\text { Habeas }\end{array}$ & $\begin{array}{l}\text { Claims Not Cognizable on } \\
\text { Habeas }\end{array}$ \\
\hline $\begin{array}{l}\text { - } \begin{array}{l}\text { Innocence-based Claims: } \\
\text { - Insufficiency of the } \\
\text { evidence } \\
\text { Brady-type claims } \\
\text { Newly discovered } \\
\text { evidence }\end{array} \\
\text { - Claim of jury or judge bias } \\
\text { Deprivation of the right to a } \\
\text { jury verdict } \\
\text { Instructional errors that } \\
\text { take the consideration of } \\
\text { elements away from jurors } \\
\text { - Deprivation of the right to a } \\
\text { public trial } \\
\text { Deprivation of counsel at } \\
\text { "critical stages" of criminal } \\
\text { proceedings } \\
\text { Ineffective assistance of } \\
\text { counsel affecting the course } \\
\text { of the entire trial } \\
\text { Denial of the right to } \\
\text { represent oneself } \\
\text { Denial of the right to } \\
\text { compulsory process } \\
\text { Denial of the privilege } \\
\text { against self-incrimination } \\
\text { Retrial or sentencing after } \\
\text { jeopardy attaches } \\
\text { Challenges to capital } \\
\text { sentencing procedures } \\
\text { Some due process violations }\end{array}$ & 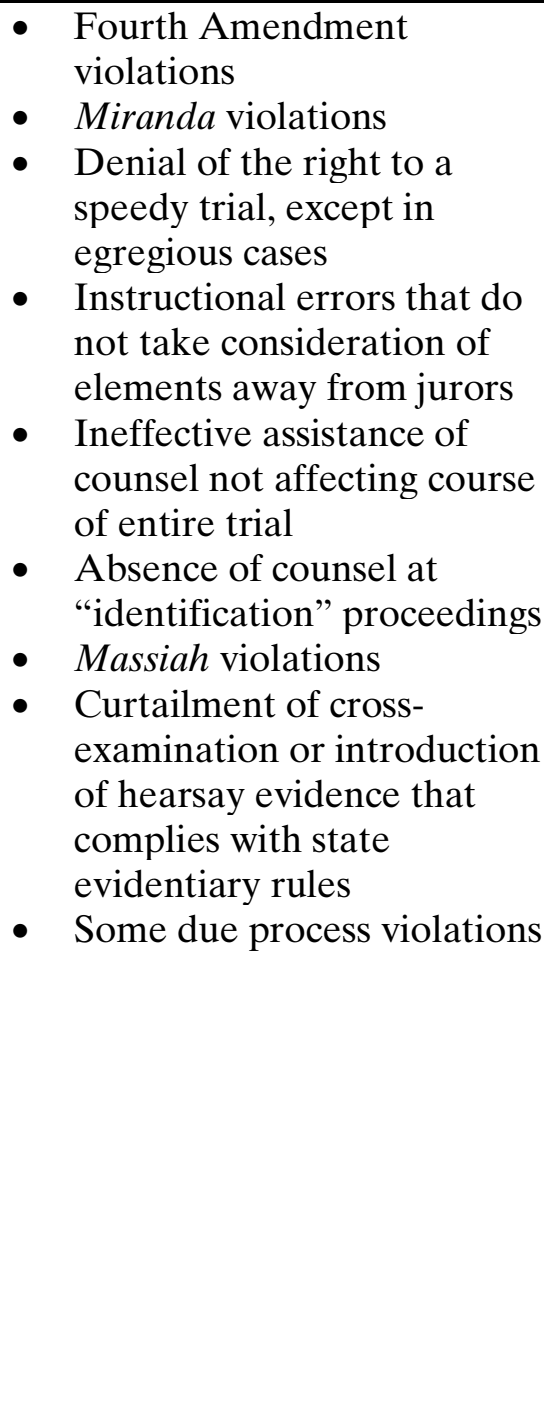 \\
\hline
\end{tabular}

Keeping the narrower substantive scope of the writ in mind, the Article now examines what should become of the procedural doctrines that had heretofore been used as an indirect tool for narrowing the availability of the writ. 


\section{REVISITING THE PROCEDURAL AsPeCtS OF HABEAS}

A major impetus behind most of the proposals to narrow the substantive scope of the federal writ of habeas corpus is the desire to replace a broad writ that effectively narrows its own availability by its labyrinthine procedures with a writ having narrower substantive breadth but fewer procedural hurdles. ${ }^{347}$ If Congress chooses to narrow the substantive scope of habeas using the combined model discussed in Part III, there would be less need for procedural screening of claims. As a result, it is important to revisit the procedural and quasi-procedural accoutrements of the current writ to determine whether they should be modified or eliminated in light of the suggested changes to the substantive scope of the writ.

\section{A. Exhaustion}

As noted in Part I, the exhaustion doctrine requires state prisoners to raise their federal constitutional claims in state court before they may be raised in federal habeas. ${ }^{348}$ Under the combined fundamental fairness/appellate model proposed in Part III, state prisoners seeking to relitigate claims on federal habeas should continue to be required to exhaust their claims in state court. ${ }^{349}$ Exhaustion mirrors the general requirement that litigants preserve claims in lower courts before raising them on appeal. ${ }^{350}$ This allows the state courts the first opportunity to consider the claims of their own prisoners, and it creates a record and decision for the federal court to examine during the habeas "appeal." This requirement should therefore be retained.

347. See supra note 50 and accompanying text.

348. See supra text accompanying notes 15-18.

349. The requirement should also be retained for state prisoners who are permitted to proceed in federal habeas because they did not have a "full and fair opportunity" to raise their federal constitutional claims in the state courts. Of course, these petitioners will necessarily be able to satisfy the exhaustion requirement because, by definition, "there is an absence of available State corrective process" and this absence meets the exhaustion requirement. 28 U.S.C. $\S 2254$ (b)(1)(B)(i) (Supp. III 1997).

350. See Liebman, supra note 109, at 2094-95 ("Via the exhaustion doctrine, the Court recently has assured that habeas corpus petitioners, like direct appellants, cannot seek the reviewing court's consideration before seeking the prior court's judgment."); $c f$. Friedman, Two Habeas, supra note 1, at 317 (noting that a separate exhaustion requirement is unnecessary in light of the general rule that a litigant must preserve claims before lower tribunals). 


\section{B. Procedural Default}

The doctrine of procedural default gives force to state procedural rules on federal habeas by barring habeas courts in most cases from reviewing the merits of any federal constitutional claim that the state courts declined to reach because of the prisoner's failure to comply with state procedural rules. In this respect, it is similar to the general appellate rule that a claim is deemed waived if it is not raised by the appellant or otherwise addressed by the court below. ${ }^{351}$ The two doctrines are not identical, however. On direct appeal, the waiver rule is strictly enforced. ${ }^{352}$ The current procedural default doctrine, by contrast, is equitable in nature, and it permits courts to overlook defaults if the habeas petitioner can either establish "cause" and "prejudice" or demonstrate that his continued incarceration would be a "fundamental miscarriage of justice" because he is probably innocent of the crime or sentence. ${ }^{353}$

A modified version of the procedural default doctrine should be enforced under the combined fundamental fairness/appellate model of habeas. It is true that this model is based in part upon the appellate model, which dictates the adoption of an absolute rule that would bar a habeas court from hearing any defaulted claims. ${ }^{354}$ However, the absolute rule suggested by the "pure" appellate model is inappropriate for a writ also designed as a bulwark against fundamental unfairness, for it would, among other things, permit the continued incarceration of a person who is innocent on the sole ground that she did not comply with state procedural rules.

351. See, e.g., SAC and FOX Nation v. Hanson, 47 F.3d 1061, 1062 (10th Cir. 1995) (emphasizing that "[a]s a general rule we refuse to consider arguments raised for the first time on appeal" (citation and internal quotations omitted)); United States v. Flores-Payon, 942 F.2d 556, 558 (9th Cir. 1991) ("Issues not presented to the trial court cannot generally be raised for the first time on appeal.").

352. Indeed, a litigant's default of a claim in state court is a jurisdictional bar when appeal is taken from the state supreme court to the United States Supreme Court. That is because a state court's reliance on the state procedural bar acts as an "adequate" and "independent" state ground that robs the Supreme Court of jurisdiction to reach the merits of any defaulted federal claim. See Harris v. Reed, 489 U.S. 255, 260-61 (1989):

This Court long has held that it will not consider an issue of federal law on direct review from a judgment of a state court if that judgment rests on a state-law ground that is both 'independent' of the merits of the federal claim and an 'adequate' basis for the court's decision.

353. See supra text accompanying notes 23-43.

354. See Friedman, Two Habeas, supra note 1, at 298 (observing that "habeas courts [under an appellate model] would not hear defaulted claims unless they could be reviewed directly by the Supreme Court"). 
Under the proposed model, a more modest modification to the procedural default doctrine is warranted. As modified, a habeas petitioner who had the opportunity to litigate a federal constitutional claim in state court but defaulted the claim would not be entitled to have the habeas court review the merits of her claim until she either established "cause" for the procedural default or showed that her continued incarceration would be a "fundamental miscarriage of justice" because she is able to demonstrate her probable innocence of the underlying crime or sentence. Habeas petitioners who were denied an opportunity to litigate their federal claims in state court should also be subject to this rule, but they would necessarily be able to demonstrate "cause" because the state, by definition, interfered with their ability to raise the claim. ${ }^{355}$

This modified standard eliminates the requirement that a prisoner prove "prejudice" along with "cause" because a "prejudice" requirement is either unnecessary or unwarranted given the range of substantive claims still available under the narrowed writ. A "prejudice" requirement is unnecessary for the innocence-based claims that remain cognizable because those claims would already fit within the "fundamental miscarriage of justice" exception. A "prejudice" requirement would also be unwarranted for the remaining claims cognizable on habeas because those claims secure procedural protections that are available to all individuals, regardless of their guilt. Demanding a showing of prejudice before such claims could be heard would effectively deny them to guilty persons, even though those protections are guaranteed to anyone accused of a crime.

To be sure, this modified doctrine would permit any habeas petitioner the opportunity to demonstrate his innocence or to show cause for his default in order to proceed on habeas notwithstanding the procedural default in state court. But the substantive scope has been narrowed to permit relitigation of only those constitutional claims most central to fundamental fairness. It therefore makes sense that fewer barriers should stand in the way of vindicating such rights.

355. See supra note 43 . 


\section{Retroactivity}

The nonretroactivity rule announced in Teague $v$. Lane ${ }^{356}$ is an expansive one. Under current law, habeas petitioners may not avail themselves of developments in the law of constitutional criminal procedure occurring after the date upon which their convictions become final, unless the "new rule" announced in the new decisions either places "certain kinds of primary, private individual conduct beyond the power" of the criminal law to proscribe or establishes a "new procedure[] without which the likelihood of an accurate conviction is seriously diminished." ${ }^{357}$ Teague or a similar rule of nonretroactivity is considered appropriate for a writ based on a pure appellate model because, with few exceptions, it places habeas petitioners in the same position they were in at the time their convictions became final by not giving them the benefit of most post-direct appeal advances in the relevant case law. ${ }^{358}$

A general rule of nonretroactivity is unwarranted, however, for a writ based in part upon the fundamental fairness model. As Justice Stevens noted in his Rose v. Lundy ${ }^{359}$ dissent, the degree to which a particular constitutional right is deemed essential to fundamental fairness can be gauged in large part upon whether it was held to apply retroactively on habeas under the Court's pre-Teague retroactivity rules, since "the Court certainly would not allow claims of such magnitude to remain unremedied." ${ }^{, 360}$ If the substantive scope of the writ has been narrowed to allow relitigation of only those constitutional claims premised on a violation of those rights essential to fundamental fairness, as the writ described in Part III has been, habeas petitioners able to assert such claims should not be foreclosed from relying upon subsequent legal developments pertaining to those fundamental rights. Allowing habeas petitioners to relitigate claims

\footnotetext{
356. 489 U.S. 288 (1989).

357. Id. at 311, 313 (plurality) (citation and internal quotations omitted).

358. See Liebman, supra note 109, at 2007 ("In substance ... the nonretroactivity bar [of Teague] actually preserves parity between direct and habeas corpus review.").

359. 455 U.S. 509 (1982).

360. Id. at $544 \mathrm{n} .8$ (Stevens, J., dissenting) ("In ruling that a constitutional principle is not to be applied retroactively, the Court implicitly suggests that the right is not necessary to ensure the integrity of the underlying judgment."). Not surprisingly, Justice Stevens took the Teague majority to task for narrowing its second exception for "fundamental fairness" solely to those claims relevant to the accuracy of the guilty verdict. In his view, this narrower definition would preclude some rights essential to fundamental fairness from being applied retroactively, despite their importance. See id. at 321-23 (Stevens, J., dissenting).
} 
premised on violations of the rights cognizable on habeas under the fundamental fairness/appellate model also permits the federal district courts hearing these claims to participate in the crafting of the law affecting these most fundamental of constitutional rights, a valuable function given the Supreme Court's inability to hear all direct appeals involving those rights. ${ }^{361}$

This logic does not apply to those habeas petitioners who are permitted to proceed in federal court with other, less fundamental constitutional claims solely because the state court denied them a "full and fair opportunity" to litigate their claims. To the extent these petitioners are not raising any of the claims designated as essential to fundamental fairness, the argument for allowing them to avail themselves of subsequent advances in the law is less compelling. Moreover, for them, federal habeas is simply taking the place of the direct appeal that they were denied. These petitioners should therefore be confined to the law as it existed at the time that they would have had their direct appeal, and some variant of Teague should apply to them.

\section{Standard of Review}

Until recently, habeas courts deferred to state courts' findings of fact by reviewing them for clear error but made an independent, de novo assessment on questions of federal law and on the mixed questions involving the application of that law to specific facts. ${ }^{362}$ In the last seven years, however, this bifurcated standard of review has come into question. Justice Thomas's three-Justice plurality in Wright $v$. $W_{e s t} t^{363}$ suggested (but did not hold) that questions of law and mixed questions of law and fact should be reviewed solely for their reasonableness. ${ }^{364}$ Under this potential new standard, which Justice Thomas would derive from Teague, federal courts would not be permitted to

\footnotetext{
361. See Steiker, Incorporating, supra note 82 , at 866 ("Were the lower federal courts not enlisted in the effort [to review the constitutional claims of state prisoners], federal habeas would surely cease to exist as an effective remedy for state prisoners."); cf. Friedman, Habeas and Hubris, supra note 105, at 799-800 ("In Teague v. Lane and its progeny, the Supreme Court silenced the habeas courts.”). Of course, lower courts usually craft constitutional law not by departing from precedent, but by applying that precedent to factual circumstances not previously encountered by the Supreme Court.

362. See supra text accompanying note 55 .

363. 505 U.S. 277 (1992).

364. See id. at 294 (plurality) (discussing petitioner's argument that "if deferential review for reasonableness strikes an appropriate balance with respect to purely legal claims, then it must strike an appropriate balance with respect to mixed questions as well").
} 
correct a state court's interpretation or application of federal constitutional law as long as that interpretation or application was not unreasonable, even if the federal court would have decided the issue differently itself. ${ }^{365}$ Congress appears to have codified this rule of deference to state court findings of law and mixed questions of law and fact in AEDPA, which provides that the writ must be denied unless the state court's "decision ... was contrary to, or involved an unreasonable application of, clearly established Federal law, as determined by the Supreme Court of the United States." 366 As noted above, the Supreme Court just this Term held that this language restricted habeas relief to three situations: (i) when "the state court applies a rule that contradicts the governing law set forth in [the Supreme Court's] cases"; ${ }^{367}$ (ii) when "the state court decides a case differently than [the Supreme Court] has on a set of materially indistinguishable facts"; ${ }^{368}$ and (iii) when "the state court's application of clearly established federal law was objectively unreasonable," ${ }^{369}$ even if the federal court would have concluded "in its own independent judgment that the relevant state court decision applied clearly established federal law erroneously or incorrectly." 370

Under this Article's proposed combined writ, the original bifurcated standard of review would be restored. This approach is consistent with a pure appellate model because it mirrors the standard of review most state courts and the U.S. Supreme Court apply on direct review, that is, de novo review. ${ }^{371}$ This approach also makes sense for a writ that is confined to relitigation of only those rights essential to fundamental fairness, because it seems wrong to require federal courts to stand idly by when a state court interprets or applies such fundamental constitutional rights in an incorrect, but not unreason-

\footnotetext{
365. Justice Thomas read Teague's definition of when a rule is "new"-that is, when the rule is "subject to debate among reasonable minds" - as indicating the Court's willingness to defer to state courts on questions of federal constitutional law. See id. at 291-92 He then reasoned that mixed questions should also receive deferential review: "[I]f deferential review for reasonableness strikes an appropriate balance with respect to purely legal claims, then it must strike an appropriate balance with respect to mixed questions as well." Id. at 294.

366. 28 U.S.C. § 2254(d)(1) (Supp. III 1997).

367. Williams v. Taylor, 120 S. Ct. 1495, 1519 (2000).

368. Id. at 1523 .

369. Id. at 1521 .

370. Id. at 1522 .

371. See supra note 55; cf. Chen, supra note 57, at 607 ("The new habeas statute [with its deferential standard of review] is an all out assault on [the appellate model].").
} 
able, manner. ${ }^{372}$ Limiting habeas courts to correcting unreasonable applications also "inhibits their participation in the law's development by preventing them from articulating reasoned expositions of constitutional principle." 373

The bifurcated standard of review should also apply to habeas prisoners denied a "full and fair opportunity" to litigate their claims in state court. For them, federal habeas review is a substitute for a direct appeal. It is therefore appropriate that the same bifurcated standard of review be applied on habeas that would have been applied on direct review. In addition, in cases where there is a total denial of the opportunity to litigate a claim, there may be no findings on questions of law or mixed questions of law and fact to which to defer.

\section{E. Standard for Relief}

One of the final issues a habeas court must resolve is what remedy is appropriate once it concludes that a state prisoner's constitutional rights have been violated. Until the Supreme Court's decision in Brecht v. Abrahamson, ${ }^{374}$ it was generally assumed that the standard for relief set down in Chapman v. California ${ }^{375}$ and Arizona v. Fulminante ${ }^{376}$ for review on direct appeal also applied on habeas. Under Chapman and Fulminante, constitutional violations falling within the narrow list of "structural errors" entitle a petitioner to automatic reversal, while other errors require reversal only if the government cannot demonstrate that the error is "harmless beyond a reasonable doubt." 377 The Court's 1993 Brecht decision setting forth the standard

372. See Chen, supra note 57, at 543-44 (arguing that reasonableness review "severely limits any deterrent function that habeas could possibly serve by significantly depriving federal courts of the power to review state court decisions in a meaningful way"); Liebman, supra note 109, at 2032 (claiming that "the writ's deterrent purpose is ill-served . . . by allowing state courts to misapply existing law as long as they do so 'reasonably"'); $c f$. Woolhandler, supra note 105, at 640 ("The overall effect of focusing on reasonable interpretations of law outside the agency context is to delegate power to interpret the Constitution to subordinate officers. That power, in turn, allows officials to inflict discrete random constitutional harms subject to little or no federal judicial review.").

373. Chen, supra note 57 , at 539.

374. 507 U.S. 619 (1993).

375. 386 U.S. 18 (1967).

376. 499 U.S. 279 (1991).

377. Chapman, 386 U.S. at 24; see also Fulminante, 499 U.S. at 297 (requiring the state to establish, beyond a reasonable doubt, that the improper admission of a confession was harmless error); supra text accompanying notes 62-69. 
for relief on federal habeas retained the per se reversal rule for structural errors but made it more difficult to obtain reversal for other errors by requiring the habeas petitioner to show that "the error "had substantial and injurious effect or influence in determining the jury's verdict." "378

Brecht's more deferential standard should not apply when habeas courts are relitigating constitutional claims under the combined fundamental fairness/appellate model. All of the claims cognizable by this combined model are, by definition, critical to assuring the fundamental fairness of the criminal process. Indeed, the violation of several of these rights is already "structural error" subject to automatic reversal. ${ }^{379}$ While there is a good argument that the violation of any of these particular rights should be "structural error," their importance to fundamental fairness at the very least counsels strongly against the application of a more deferential standard for relief like the one announced in Brecht.

Brecht's standard should also not be applied when the habeas petition is raising claims for which the state did not provide a "full and fair opportunity" for litigation. Again, in this situation, habeas acts as a substitute for a direct appeal, and it seems only equitable that petitioners in this situation be treated no worse than they would have been had they received a direct appeal. Chapman's standard is therefore the appropriate standard to be applied in this context.

\section{The CONSTITUtionality OF A NARRower Statutory Writ}

Before a Congress inclined to narrow the federal writ of habeas corpus were to do so along the lines suggested in Parts III and IV of this Article, it is important to assess whether the newly constituted writ would comport with the Constitution. As noted above, this Article has focused on changes to the statutory writ of habeas corpus con-

378. Brecht, 507 U.S. at 637 (quoting Kotteakos v. United States, 328 U.S. 750, 776 (1946)); cf. O'Neal v. McAninch, 513 U.S. 432, 436-37 (1995) (declining to classify any particular party as having the "burden of proof" in concluding that a judge who entertains "grave doubt" about the effect of an error under Brecht should award relief). Brecht recognized that its new, more deferential rule might not apply

in an unusual case [where] a deliberate and especially egregious error of the trial type, or one that is combined with a pattern of prosecutorial misconduct, might so infect the integrity of the proceeding as to warrant the grant of habeas relief, even if it did not substantially influence the jury's verdict.

Brecht, 507 U.S. at 638 n.9.

379. Compare supra text accompanying notes 62-67, with supra Part III.B. 
tained in section 2254 , which specifically addresses the claims of persons in state custody. ${ }^{380}$ However, there are other statutory writs, and perhaps even a common law writ, of habeas corpus. ${ }^{381}$ In order to effectively narrow the writ for state prisoners, Congress would need to be sure to close off these other writs, or else modifications to section 2254 would be rendered superfluous by the availability of these other remedies. ${ }^{382}$ This section proceeds on the assumption that section 2254 as modified is the only writ available, ${ }^{383}$ briefly sketches out the four possible constitutional inquiries, and offers some observations on the probable outcome of those inquiries.

The Constitution's primary limitation on the writ is the Suspension Clause, which provides that "[t]he Privilege of the Writ of Habeas Corpus shall not be suspended, unless when in Cases of Rebellion or Invasion the public Safety may require it." ${ }^{384}$ The language of this constitutional provision is particularly unhelpful in ascertaining the limits of Congress's power to modify the federal writ of habeas corpus. As an initial matter, the text of the Clause only prohibits a suspension of the writ. It does not require that Congress even create the writ, although a bar on suspending the writ would appear to imply a duty to create some writ in the first place. ${ }^{385}$ The Clause also does

\footnotetext{
380. See supra note 1.

381. See supra note 1.

382. Congress's failure to explicitly eliminate $\S 2241$ as an alternative remedy for persons wishing to raise challenges to deportation in the immigration context has led many courts of appeals to conclude that $\S 2241$ remains a viable remedy, even though Congress appears to have intended to foreclose all relief in that context. See, e.g., Pak v. Reno, 196 F.3d 666, 673 (6th Cir. 1999); Jurado-Guiterrez v. Greene, 190 F.3d 1135, 1146 (10th Cir. 1999); Requena-Rodriguez v. Pasquarell, 190 F.3d 299, 305 (5th Cir. 1999); Shah v. Reno, 184 F.3d 719, 724 (8th Cir. 1999); Selgeka v. Carroll, 184 F.3d 337, 342 (4th Cir. 1999); Mayers v. INS, 175 F.3d 1289, 1300-01 (11th Cir. 1999); Sandoval v. Reno, 166 F.3d 225, 231 (3d Cir. 1999); Henderson v. INS, 157 F.3d 106, 112 (2d Cir. 1998), cert. denied, 119 S. Ct. 1141 (1999); Magana-Pizano v. INS, 152 F.3d 1213, 1214 (9th Cir. 1998), vacated, 119 S. Ct. 1137 (1999); Goncalves v. Reno, 144 F.3d 110, 113 (1st Cir. 1998), cert. denied, 119 S. Ct. 1140 (1999).

383. The Supreme Court held as much in Brown v. Allen, 344 U.S. 443, 486 (1953) ("[F]ederal courts may not grant habeas corpus for those convicted by the state except pursuant to $\$ 2254 . ")$.

384. U.S. CONST. art. I, § 9, cl. 2. Jordan Steiker has argued that the Suspension Clause should be incorporated through the Fourteenth Amendment to the States, with the synergy of the two provisions creating "mandat[ory] federal habeas review of the convictions of state prisoners." Steiker, Incorporating, supra note 82, at 868.

385. See Steiker, Incorporating, supra note 82, at 864 (pointing out that "the Clause might simply limit Congress's ability to abolish a judicial remedy that it is not elsewhere required to establish").
} 
not elaborate on the constitutionally required contours of the writ, and the Supreme Court has assiduously avoided the issue. ${ }^{386}$

Given this ambiguity, it is not surprising to see that the courts and commentators have identified four possible meanings for the Clause. Some have contended that the Suspension Clause demands that Congress maintain no more than a writ of habeas corpus comparable to the writ that existed in $1789 .{ }^{387}$ Because the writ at that time assured little more than conviction in a court of competent jurisdiction, ${ }^{388}$ this first interpretation would accord Congress great latitude in modifying the statutory writ. Under this interpretation, there would seem to be little danger of constitutional infirmity if the writ were amended to comport with the fundamental fairness/appellate model.

At least one commentator has argued that the Suspension Clause precludes Congress from narrowing the writ beyond its contours as of 1868, when Congress adopted the Fourteenth Amendment and at the same time expanded the writ to make it generally available to state prisoners in all cases where a person was "restrained of his or her liberty in violation of the Constitution, or of any treaty or law of the United States." ${ }^{389}$ To be sure, the writ in 1867 was broader than the writ in $1789 .^{390}$ Since 1789 , Congress had twice amended the writ to afford relief to state prisoners if they had been "committed ... for any act done... in pursuance of a law of the United States" or were a

386. See, e.g., Felker v. Turpin, 518 U.S. 651, 663-64 (1996) (assuming, but explicitly not deciding, that the Suspension Clause "refers to the writ as it exists today"); Swain v. Pressley, 430 U.S. 372, 380 n.13 (1976) (finding "no occasion" to define the contours of constitutional limits on congressional modification of the writ).

387. See, e.g., Swain, 430 U.S. at 384 (Burger, C.J., concurring) ("The sweep of the Suspension Clause must be measured by reference to the intention of the Framers and their understanding of what the writ of habeas corpus meant at the time the Constitution was drafted."); Friendly, supra note 92, at 170 ("It can scarcely be doubted that the writ protected by the suspension clause is the writ as known to the framers, not as Congress may have chosen to expand it.").

388. See supra text accompanying notes 95-96.

389. Steiker, Incorporating, supra note 82 , at 888 ("If the 'right' to habeas corpus is properly located in the Fourteenth Amendment, the contours of that right must be discussed in light of the writ's transformation between 1789 and 1868."). See Act of Feb. 5, 1867, ch. 28, 14 Stat. 385, 385 . As noted above, the 1789 writ reached only persons in federal custody and did not specify the possible grounds for release. See Act of Sept. 24, 1789, ch. 20, § 14, 1 Stat. 81, 82 (providing that the writ is available to prisoners "in custody, under or by colour of the authority of the United States, or ... committed for trial before some court of the same").

390. See Steiker, Incorporating, supra note 82 , at 881 ("[I]t is simply wrong to assert that the writ known to the framers of the Fourteenth Amendment was the same narrowly circumscribed writ known at English law, or perhaps even known to the Framers of the Suspension Clause."). 
"subjects or citizens of a foreign State, and domiciled therein." ${ }^{391}$ But despite the plain language of the amended writ and its application to state prisoners, the writ still failed to afford relief in many situations until well into the twentieth century. ${ }^{392}$ As a result, the modified writ discussed in this Article would likely pass muster under this historical view of the Suspension Clause as well.

Still others have argued that the Suspension Clause secures the statutory writ as it exists today, such that any curtailment of the substantive scope of the writ is potentially unconstitutional. ${ }^{393}$ While this approach would surely render invalid any attempts to modify the writ along the lines suggested in this Article, the validity and wisdom of this approach are questionable. Stone v. Powell ${ }^{394}$ removed Fourth Amendment claims from the substantive scope of habeas over thirty years ago. ${ }^{395}$ If the Suspension Clause barred any narrowing of the writ, Stone would be unconstitutional, but it has not been so declared. The recent congressional amendments to habeas procedure contained in AEDPA, which have the effect of eliminating relief on habeas, would also be unconstitutional, but they have also not been declared to be. ${ }^{396}$ Equating the statutory writ with the constitutional writ may be imprudent as a policy matter as well. As noted above, Congress and the courts have greatly expanded (and, at times, narrowed ${ }^{397}$ ) the reach of habeas corpus over the past two hundred years. Interpreting

391. See supra note 4.

392. As one might expect, there is disagreement over whether the Court was interpreting the writ narrowly, see Bator, supra note 91 , at 469-71, or whether the Court was interpreting the writ to reach all constitutional claims, but few such claims were available at the time, see Peller, supra note 5 , at 618,630 . While both interpretations of history are partially correct, see supra note 109 , the undeniable bottom line is that the statutory writ - no matter what the reason-did not afford relief in very many situations until the 1960 s.

393. The Ninth Circuit recently so held in Magana-Piazno v. INS, 152 F.3d 1213, 1218 (9th Cir.) (emphasizing that "we assess the writ which the Constitution protects against suspension 'as it exists today, rather than as it existed in 1789'” (quoting Felker v. Turpin, 518 U.S. 651, 664 (1996))), amended, 159 F.3d 1217 (9th Cir. 1998), vacated, 119 S. Ct. 1137 (1999). The Ninth Circuit's original holding on this point, however, rests on a misreading of Felker, which simply assumed that the current statutory writ was the proper benchmark but did not definitively so hold. See Felker, 518 U.S. at 663-64.

394. 428 U.S. 465 (1976).

395. See id. at 494-95 (holding that, after having an "opportunity for full and fair litigation of a Fourth Amendment claim, the Fourth Amendment exclusionary rule cannot be used as a ground for habeas").

396. See Felker, 518 U.S. at 664 (upholding AEDPA's restrictions limiting the ability of habeas petitioners to file multiple petitions).

397. See, e.g., Ex parte McCardle, 74 U.S. (7 Wall.) 506, 506-07 (1869) (reviewing Congress's 1868 elimination of the Supreme Court's appellate jurisdiction over habeas petitions). 
the Constitution to forbid any narrowing "would create an irrational ratchet," because "[h]abeas corpus could always be enlarged, but once enlarged could not be returned to its previous, less generous scope without a constitutional amendment." ${ }^{398}$ For these reasons, the Supreme Court may ultimately decide not to adopt this view of the Suspension Clause, and thus the writ proposed in this Article would not be invalidated under such an interpretation.

In Felker v. Turpin, ${ }^{399}$ the Supreme Court's most recent opinion on the meaning of the Suspension Clause, the Court may have coined a fourth approach to assessing the constitutionality of modifications to the federal writ of habeas corpus. In that case, the Court upheld AEDPA's new restrictions on the filing of subsequent habeas petitions because they were "well within the compass of [the] evolutionary process" of habeas, which was described by the Court as "'a complex and evolving body of equitable principles informed and controlled by historical usage, statutory developments, and judicial decisions." ""400 In light of the Court's and, more recently, Congress's curtailment of the writ by tightening the procedural screws of habeas, as well as the Court's flirtation with narrowing the substantive scope of habeas in Stone and its progeny, a statutory modification that exchanges some of the procedural hurdles for a focus on rights essential to fundamental fairness would not seem outside this evolutionary process, particularly when one takes into account the historical narrowness of the writ. The modified writ suggested in this Article is likely to satisfy the Felker Court's conception of the Suspension Clause.

In light of this cursory analysis, it appears likely that Congress would not run afoul of the Suspension Clause if it proceeded to narrow the substantive scope of the federal writ, either one piece at a time or in toto, in accordance with the fundamental fairness/appellate model described in Parts III and IV.

398. LaGuerre v. Reno, 164 F.3d 1035, 1038 (7th Cir. 1998), cert. denied, 120 S. Ct. 1157 (2000).

399. 518 U.S. 651 (1996).

400. Id. at 664 (quoting McCleskey v. Zant, 499 U.S. 467, 489 (1991)); accord LaGuerre, 164 F.3d at 1039 ("We are suggesting not that the meaning of habeas corpus in the suspension clause was set in stone in 1787 ... but only that the meaning of the constitutional term does not move in lockstep with changes in the meaning of the statutory term."). 


\section{CONCLUSION}

In the last few decades, the Supreme Court has created a labyrinth of procedural hurdles for state prisoners seeking relief under the federal writ of habeas corpus, but it has only twice tinkered with the substantive scope of the writ-in Stone v. Powell and its progeny, and in Teague v. Lane. More recently, Congress has started to consider legislation that would eliminate certain types of claims from habeas review. Although these efforts to narrow the universe of claims cognizable on habeas are a more straightforward means of reducing the actual availability of the writ than creating new and complex procedural hurdles, tinkering with the scope of the writ can be just as problematic if it is not done rationally.

This Article has attempted a comprehensive exploration of how a Congress intent upon narrowing the substantive scope of the statutory writ might proceed. Even if Congress were to eliminate one or two claims at a time from the reach of federal habeas, it should have an underlying and coherent theory of the purpose and role of habeas review in mind. After examining several theories, the Article concludes that the most appropriate theory is one that recognizes both the role of habeas as a bulwark against fundamental unfairness and its function today as an additional "appeal" from state court. Under this hybrid theory, the only constitutional claims that would be subject to relitigation on federal habeas are those for which it would be fundamentally unfair to deny an additional appeal in federal court. The Article has also described which constitutional claims would be likely to satisfy this standard, detailed how the procedural doctrines that were previously used to screen claims should be modified, and examined whether this newly constituted writ would be constitutional under the Suspension Clause. In the end, this combined theory may provide a workable model for creating a writ that raises fewer procedural roadblocks but that still continues to assure justice to state prisoners who are wrongly incarcerated. 